medRxiv preprint doi: https://doi.org/10.1101/2022.02.04.22270304; this version posted February 6, 2022. The copyright holder for this preprint (which was not certified by peer review) is the author/funder, who has granted medRxiv a license to display the preprint in It is made available under a CC-BY-NC-ND 4.0 International license .

\title{
Effective high-throughput RT-qPCR screening for SARS-CoV-2 infections in
} children

Felix Dewald ${ }^{1,4 *}$, Isabelle Suárez ${ }^{2,3,4 *}$, Ronja Johnen ${ }^{5}$, Jan Grossbach ${ }^{5}$, Roberto Moran Tovar 6 , Gertrud Steger ${ }^{1}$, Alexander Joachim7, Gibran Horemheb Rubio ${ }^{1}$, Mira Fries ${ }^{8}$, Florian Behr ${ }^{8}$, Joao Kley ${ }^{3}$, Andreas Lingnau ${ }^{26}$, Alina Kretschmer ${ }^{3}$, Carina Gude ${ }^{5}$, Guadelupe Beazes-Flores ${ }^{9}$, David Laveaga del Valle ${ }^{9}$, Alberto Roblero-Hernandez ${ }^{9}$, Jesus Magana-Cerino ${ }^{9}$, Adriana Torres Hernandez ${ }^{10}$, Jesus Ruiz-Quinones ${ }^{9}$, Konstantin Schega ${ }^{9}$, Viktoria Linne ${ }^{3}$, Lena Junker ${ }^{3}$, Marie Wunsch ${ }^{1}$, Eva Heger ${ }^{1}$, Elena Knops $^{1}$, Veronica Di Cristanziano ${ }^{1}$, Meike Meyer ${ }^{7}$, Christoph Hünseler ${ }^{7}$, Lutz T. Weber $^{7}$, Jan-Christoffer Lüers ${ }^{11}$, Gustav Quade ${ }^{12}$, Hilmar Wisplinghoff ${ }^{13}$, Carsten Tiemann ${ }^{14}$, Rainer Zotz ${ }^{15}$, Hassan Jomaa ${ }^{16}$, Arthur Pranada ${ }^{17}$, Ileana Herzum ${ }^{18}$, Paul Cullen ${ }^{19}$, Franz-Josef Schmitz ${ }^{20}$, Paul Philipsen ${ }^{21}$, Georg Kirchner ${ }^{22}$, Cornelius Knabbe $^{23}$, Martin Hellmich ${ }^{24}$, Michael Buess ${ }^{8}$, Anna Wolf ${ }^{8}$, Annelene Kossow ${ }^{8}$, Johannes Niessen ${ }^{8}$, Sebastian Jeworutzkii ${ }^{25}$, Jörg-Peter Schräpler ${ }^{25}$, Michael Lässig ${ }^{6}$, Jörg Dötsch ${ }^{7}$, Gerd Fätkenheuer ${ }^{2,3}$, Rolf Kaiser ${ }^{1}$, Andreas Beyer ${ }^{5 *}$, Jan Rybniker ${ }^{2,3,4 *}$, Florian Klein ${ }^{1,2,4 *}$

\section{Affiliations}

1. Institute of Virology, Faculty of Medicine and University Hospital Cologne, University of Cologne, Cologne, Germany

2. German Center for Infection Research, Partner Site Bonn-Cologne, Cologne, Germany

3. Department I of Internal Medicine, Division of Infectious Diseases, University Hospital Cologne, University of Cologne, Cologne, Germany

4. Center for Molecular Medicine Cologne, University of Cologne, Cologne, Germany.

5. CECAD Research center, University of Cologne, Cologne, Germany

6. Institute for Biological Physics, University of Cologne, Cologne, Germany

7. Department of Pediatrics, Children's and Adolescents' Hospital, University Hospital Cologne, Faculty of Medicine, University of Cologne, Cologne, Germany

8. Health department of Cologne, Cologne, Germany

9. Centro de Investigación en Enfermedades Tropicales y Emergentes, Hospital Regional de Alta Especialidad, Dr. Juan Graham Casasús, Villahermosa, Mexico

10. Bioclilab SA de CV, Villahermosa, Mexico

11. Department of Otorhinolaryngology, Head and Neck Surgery, University of Cologne, Cologne

12. MVZ Labor Dr. Quade \& Kollegen GmbH, Cologne, Germany NOTE: This preprint reports new research that has not been certified by peer review and should not be used to guide clinical practice. 13. Labor Dr. Wisplinghoff, Cologne, Germany 
medRxiv preprint doi: https://doi.org/10.1101/2022.02.04.22270304; this version posted February $6,2022$. The copyright holder for this preprint (which was not certified by peer review) is the author/funder, who has granted medRxiv a license to display the preprint in It is made available under a CC-BY-NC-ND 4.0 International license .

14. Labor Krone, Bad Salzuflen, Germany

15. Labor ZotzKlimas, Düsseldorf, Germany

16. Synlab, Leverkusen, Germany

17. Medizinisches Versorgungszentrum Dr. Eberhard \& Partner, Dortmund, Germany

18. Medizinische Laboratorien Düsseldorf, Düsseldorf, Germany

19. MVZ Labor Münster, Münster, Germany

20. Mühlenkreiskliniken, Minden, Germany

21. Labor Mönchengladbach MVZ Dr. Stein und Kollegen, Mönchengladbach, Germany

22. Eurofins Laborbetriebsgesellschaft Gelsenkirchen GmbH \& Eurofins MVZ Medizinisches Labor Gelsenkirchen $\mathrm{GmbH}$, Gelsenkirchen, Germany

23. Heart- and Diabetes Center NRW, Medical Faculty, Ruhr-University Bochum, Institute for Laboratory and Transfusion Medicine, Bochum, Germany

24. Institute of Medical Statistics and Computational Biology, Faculty of Medicine and University Hospital Cologne, University of Cologne

25. Faculty of Social Science, Ruhr-University Bochum, Bochum, Germany

26. Ministry of Schools and Education of North Rhine-Westphalia, Düsseldorf, Germany

* contributed equally to this manuscript 
medRxiv preprint doi: https://doi.org/10.1101/2022.02.04.22270304; this version posted February 6,2022 . The copyright holder for this preprint (which was not certified by peer review) is the author/funder, who has granted medRxiv a license to display the preprint in It is made available under a CC-BY-NC-ND 4.0 International license.

\section{Abstract}

2 Systematic SARS-CoV-2 testing is a valuable tool for infection control and

3 surveillance ${ }^{1}$. However, broad application of high sensitive RT-qPCR testing in children

4 is often hampered due to unpleasant sample collection, limited RT-qPCR capacities,

5 and high $\operatorname{costs}^{2-4}$. Here, we developed a high-throughput approach ('Lolli-Method') for

6 sensitive SARS-CoV-2 detection in children, combining non-invasive sample collection

7 with an RT-qPCR-pool testing strategy. SARS-CoV-2 infections were diagnosed with

8 sensitivities of $100 \%$ and $93.9 \%$ when viral loads were $>10^{6}$ copies $/ \mathrm{ml}$ and $>10^{3}$

9 copies/ml in corresponding Naso-/Oropharyngeal-swabs, respectively. For effective

10 application of the Lolli-Method in schools and daycare facilities, SIR-modeling indicated

11 a preferred frequency of two tests per week. The developed test strategy was

12 implemented in 3,700 schools and 698 daycare facilities in Germany, screening over

13800,000 individuals twice per week. In a period of 3 months, 6,364 pool-RT-qPCRs

14 tested positive (0.64\%) ranging from $0.05 \%$ to $2.61 \%$ per week. Notably, infections

15 correlated with local SARS-CoV-2 incidences as well as with a school social

16 deprivation index. Moreover, in comparison with the alpha variant, statistical

17 modeling revealed a $31 \%$ increase for multiple ( $\geq 2$ children) infections per class

18 following infections with the delta variant ${ }^{5}$. We conclude that the Lolli-Method is a

19 powerful tool for SARS-CoV-2 surveillance and infection control in schools and daycare

20 facilities.

Introduction

23 The clinical course of COVID-19 in children is generally mild ${ }^{6,7}$. However, severe

24 courses, deaths, and post-acute COVID-19 syndrome have been described and pose

25 a risk to children when exposed to SARS-CoV-28,9. Moreover, viral loads measured in

26 infected children can be as high as those in adults ${ }^{10}$, which is consistent with the 
medRxiv preprint doi: https://doi.org/10.1101/2022.02.04.22270304; this version posted February 6,2022 . The copyright holder for this preprint (which was not certified by peer review) is the author/funder, who has granted medRxiv a license to display the preprint in It is made available under a CC-BY-NC-ND 4.0 International license .

27 transmission of SARS-CoV-2 among children and from children to adults ${ }^{11}$. In order to 28 control SARS-CoV-2 infections, schools have been closed worldwide, resulting in the 29 loss of approximately $50 \%$ of all school lessons in $2020^{12}$. However, while school closures can reduce SARS-CoV-2 transmissions when imbedded in a general lock31 down strategy, the negative impact on the development and health of children is 32 substantial and is manifested by e.g. higher rates of reduced emotional well-being, severe eating disorders, and overt psychiatric disease ${ }^{13-15}$. Early detection of SARS-CoV-2 infections can contribute to infection control ${ }^{1}$. In addition, SARS-CoV-2 surveillance in schools allows to determine the efficiency of non-pharmaceutical interventions $(\mathrm{NPIs})^{16}$. Therefore, several test strategies for schools and daycare facilities have been developed. In these, samples were mostly obtained by self-sampling using rapid antigen detection tests (RADTs) or RT-qPCR analyses ${ }^{17-20}$. However, various challenges remain including reduced sensitivity of RADTs $^{21}$, acceptance of specimen collection by children ${ }^{2}$, and limited RT-qPCR

41 capacities $^{4}$. Despite the recent authorization for SARS-CoV-2 vaccines in children aged 5-11 years ${ }^{22}$, effective and sound test strategies remain critical to ensure infection control in open schools and daycare facilities. This is particularly important considering the dynamic situation of the SARS-CoV-2 pandemic in which new variants of concerns (VOCs) emerge and spread ${ }^{23}$. Here, we developed a non-invasive sampling approach combined with high-throughput pooled RT-qPCR testing (Lolli-Method) followed by the

47 design of a test concept for schools and daycare facilities. This test concept was successfully implemented as a SARS-CoV-2 screening program for over 800,000 children and demonstrated a precise monitoring and early detection of SARS-CoV-2 infections. 
medRxiv preprint doi: https://doi.org/10.1101/2022.02.04.22270304; this version posted February 6, 2022. The copyright holder for this preprint (which was not certified by peer review) is the author/funder, who has granted medRxiv a license to display the preprint in It is made available under a CC-BY-NC-ND 4.0 International license .

\section{Results}

\section{Developing the Lolli-Method to screen for SARS-CoV-2 infections in children}

A widely applicable SARS-CoV-2 screening in children requires the combination of i.) an easy, safe and non-invasive sampling method with ii.) a resource-saving, reliable and scalable SARS-CoV-2 testing method. To meet these requirements, we developed the Lolli-Method by which a regular swab is used for self-sampling, i.e. to be sucked on for 30 seconds (Lolli-swab), combined with a pooled RT-qPCR analysis. In order to determine the sensitivity of this method, we investigated 254 acutely infected individuals in a side-by-side sampling approach using Nasopharyngeal/Oropharyngeal (Np-/Op) versus Lolli-swab. Lolli-swabs were collected under supervision and all samples were analyzed by RT-qPCR (Fig. 1a, Extended data Fig. 1). By using the Lolli-Method, 95 out of 118 infected individuals were detected when sampled in the morning and 101 out of 153 when sampled during the day. Detected viral loads obtained by the Lolli-Method were lower (geometric mean $2.22 \times 10^{3}$ copies/ml) than viral loads measured in Np-/Op-swabs (geometric mean 6.36x104 copies/ml, p<0.0001, Fig. 1b and 1c, Extended data Table 1a). However, while Lolliswabs showed only $50 \%$ sensitivity in samples with corresponding viral loads of $<10^{3}$ copies $/ \mathrm{ml}$, diagnostic sensitivities of $91.4 \%$ and $100 \%$ were reached for matched $\mathrm{Np}$ /Op-swabs with viral loads of $10^{3}-10^{6}$ and $>10^{6}$ copies $/ \mathrm{ml}$, respectively (Figure 1d). Next, we determined the impact on the sensitivity by having food and liquid intake one hour before sampling (Fig. 1e, Extended data Table 1b), the use of different swabtypes (Fig. 1f, Extended data Table 1c) and the dilution effect by the pooling-process (Fig. 1g, Extended data Table 1d). While different swab-types had no effect on sensitivity, breakfast one hour before sampling and pooling of up to 100 Lolli-swabs reduced the detected viral load by 2.2- and 3.3-fold, respectively. However, these differences did not result in a relevant reduction of overall sensitivity, detecting 56 out 
medRxiv preprint doi: https://doi.org/10.1101/2022.02.04.22270304; this version posted February 6,2022 . The copyright holder for this preprint (which was not certified by peer review) is the author/funder, who has granted medRxiv a license to display the preprint in It is made available under a CC-BY-NC-ND 4.0 International license .

of 57 samples despite breakfast or pooling. Finally, specificity of the Lolli-Method was found to be $100 \%$, testing 55 healthy individuals individually with $\mathrm{Np}$-/Op-and Lolliswabs (Extended data Table 1e).

We concluded that the Lolli-Method is an easy and non-invasive method that is highly sensitive in detecting infected individuals with viral loads above $10^{3}$ copies $/ \mathrm{ml}$.

\section{High-throughput Lolli-Method screening concept in children}

Next, a screening concept for schools and daycare was developed. As part of this concept, Lolli-swabs of one class or group were obtained and pooled at sampling-site, followed by RT-qPCR analysis. To this end, each child of a class received a Lolli-swab, performed self-sampling and placed it in a common $50 \mathrm{ml}$ tube (Fig. 1h). Very young children or children with disabilities received assistance by their parents or teachers.

The pooled samples were tested by SARS-CoV-2 RT-qPCR. In case the pool was tested negative, all children were assumed to be SARS-CoV-2 negative. In case the pool was tested positive, children of the positive pool were re-tested individually in order to identify the infected individuals (Fig. 1h).

To determine an optimal test-frequency, the efficiency of a long-term SARSCoV-2 screening was estimated using an extension of the SIR-model (Fig. 1i and 1j, Extended data Table 2). Simulations of 8-week-test-periods were carried out for populations of 20 individuals, performing ensemble averages of over $10^{4}$ runs. Simulations were performed for different basic reproduction values $\left(R_{0}\right)$ of SARS-CoV2 and different scenarios of SARS-CoV-2 prevalence in the general population $(0.01 \%$ and $0.1 \%$ ). The total number of infected individuals, the number of infections due to transmissions within the test-population and the number of infections detected by the screening were calculated for different test-frequencies $(0,1,2$ or 3 times per week). As a result, the proportion of prevented transmissions was $66 \%, 81 \%$, and $87 \%$ for 
medRxiv preprint doi: https://doi.org/10.1101/2022.02.04.22270304; this version posted February 6, 2022. The copyright holder for this preprint (which was not certified by peer review) is the author/funder, who has granted medRxiv a license to display the preprint in It is made available under a CC-BY-NC-ND 4.0 International license .

105 testing 1, 2, or 3 times per week, respectively (Fig. 1k). Taking logistics and limited 106 RT-qPCR capacities into account, a test-frequency of twice per week was considered most effective and was used for the subsequent implementation of a screening program.

\section{Implementing the Lolli-Method screening concept in schools and daycare}

111 The Lolli-Method screening concept was implemented as part of a governmental SARS-CoV-2 testing program in 3,700 elementary schools and special needs schools in North Rhine-Westphalia, Germany, testing 742,771 students twice a week (Fig. 2a,

114 Extended data Table 3). Testing was mandatory for all students. Students had a 115 median age of 8 years (IQR 2 years) with 354,125 (47.69\%) being female and 388,646 $116(52.32 \%)$ being male. On average, 21.1 students were registered per class and 197.3 students per school (Fig. 2b). Sampling was conducted from calendar week 19 to 37 118 in 2021, which included 8 weeks before (calendar week 19-26) and 5 weeks after 119 (calendar week 33-37) the summer holidays. During this period, the 7-day incidence in 120 North Rhine-Westphalia ranged from 14.4 to 146.7 with a maximum in calendar week 12134 (Fig. 2c). Notably, while at the beginning the variant of concern (VOC) alpha was predominant, the delta variant accounted for the majority of cases starting with calendar week 26 (Fig. 2c).

For the 3,700 schools that were located within an area of $34,098 \mathrm{~km}^{2}$, sample transport as well as RT-qPCRs were performed by 12 diagnostic laboratories (Extended data Fig. 2, Extended data Table 4). All RT-qPCR results were reported to a central database and data was checked for plausibility and invalid items were removed (Extended data Fig. 3). In total, 1,110,033 RT-qPCRs were carried out 
medRxiv preprint doi: https://doi.org/10.1101/2022.02.04.22270304; this version posted February 6, 2022. The copyright holder for this preprint (which was not certified by peer review) is the author/funder, who has granted medRxiv a license to display the preprint in It is made available under a CC-BY-NC-ND 4.0 International license .

estimating an overall SARS-CoV-2 testing of $16,943,470$ swabs within a time period of 13 weeks (Fig. 2d). Mean turn-around time for processing of pool-RT-qPCRs was 7.59 hours and 9.14 hours for single-RT-qPCRs (Extended data Fig. 4). $96.2 \%$ of all poolRT-qPCR results were communicated before 6:00 a.m. on the next day (Extended data Table 4). In addition, the Lolli-Method was applied to 698 daycare facilities in the city of Cologne, testing approximately 48,149 children within the age of 1 to 6 years and 13,577 staff members twice per week for a period of 6 months (Extended data Fig. 5). Both in schools and daycare facilities, the program was well accepted and continued beyond the reported time period.

We concluded that the Lolli-Method can be applied to educational settings including daycare facilities for high-throughput testing of SARS-CoV-2 infections.

\section{Monitoring SARS-CoV-2 infections in schools}

In total, 6,364 of 983,941 pool-RT-qPCRs in schools tested positive $(0.65 \%) .1,316$ pool-RT-qPCRs tested positive before (calendar week 19-26), while 5,048 tested positive after the summer holidays (calendar week 33-37) (Fig. 3a). The rate of positivity of pool-RT-qPCRs was $0.46 \%$ in calendar week 19 and decreased continuously to $0.05 \%$ in calendar week 26 . After the summer holidays, rate of positivity decreased from $2.61 \%$ in calendar week 33 to $0.92 \%$ in calendar week 37 (Fig. 3b). The number of infected individuals per positive pool-RT-qPCR was estimated to be 1.3 on average (Extended data Fig. 6). In order to validate the implemented Lolli-Method, we investigated all reported index-cases of children attending elementary schools in the city of Cologne from calendar week 19 to 36 ( $n=653$, Extended data Fig. 7). To this end, contact-tracing information was obtained by the local health authorities on 569 from 653 index-cases (87.1\%). When excluding index-cases that were not tested by the Lolli-Method within $72 \mathrm{~h}$ before their positive test, detection rate of the Lolli- 
medRxiv preprint doi: https://doi.org/10.1101/2022.02.04.22270304; this version posted February 6,2022 . The copyright holder for this preprint (which was not certified by peer review) is the author/funder, who has granted medRxiv a license to display the preprint in It is made available under a CC-BY-NC-ND 4.0 International license .

157 Method of confirmed index-cases was 89.1\% (Extended data Fig. 7), indicating a 158 reliable detection of SARS-CoV-2 infections in children.

159 SARS-CoV-2 7-day pool-incidence (= number of positive pool-RT-qPCRs/100.000

160 tested children in 7 days, see Methods) varied among districts from 0 to 416.2 (Fig.

161 3c) and correlated with SARS-CoV-2 incidence of the general population within a 162 district $(r=0.76, p<0.0001$; Fig. 3d). Of 3,700 participating schools, 3,648 were tested 163 before and after the summer holidays. Of those, $2,315(63.46 \%)$ schools were found 164 to have at least one positive pool-RT-qPCR result, with numbers of positive pool165 qPCRs per school ranging from $1(22.2 \%), 2(15.8 \%)$ and $3(9.5 \%)$ to a maximum of 166 $22(0.03 \%$, Fig. 3e).

Moreover, we investigated potential associations of SARS-CoV-2 infections in schools with grade levels, type of school, population density and socioeconomic status (SES) quantified using a school social deprivation index (SSDI) ${ }^{24}$. This index had been generated using a confirmatory factor analysis in which schools were assigned to social deprivation levels on a scale from 1 to 9 with 1 reflecting the highest SES and 9 the lowest. While no association between infections and grade levels or type of school was found, a moderate correlation for population density $(r=0.56, p<0.0001)$ was detected. Moreover, the SSDI strongly correlated with the average number of positive pool-RT-qPCRs per student and per school ( $r=0.94, p=0.0002)$ (Fig. $3 f$ and $\mathbf{3 g}$ ). We concluded that the Lolli-Method is capable of reliably detecting SARS-CoV-

1772 infections in schools and is a valuable tool to determine factors associated with 178 SARS-CoV-2 infections in schools. 
medRxiv preprint doi: https://doi.org/10.1101/2022.02.04.22270304; this version posted February 6, 2022. The copyright holder for this preprint (which was not certified by peer review) is the author/funder, who has granted medRxiv a license to display the preprint in It is made available under a CC-BY-NC-ND 4.0 International license .

High-throughput screening reveals differences in infection dynamics for SARS-

\section{CoV-2 variants in schools}

184 Based on molecular surveillance data published by the German public health institute (Robert Koch Institute) (Fig. 2c), we estimated the fraction of positive pool-RT-qPCRs assigned to the alpha variant (B.1.1.7) to be $92.9 \%$ before the summer holidays while 99.54\% were assigned to the delta variant (B.1.167.2) after the summer holidays (Fig.

4a). Mean Cycle threshold (Ct)-values of positive pool-RT-qPCRs decreased significantly after the summer holidays, with an average Ct-value of 33.61 before (alpha variant) and 32.55 after (delta variant) the summer holidays $(p<0.0001$, Mann-Whitney test). While the overall difference was small (1.06 Ct-values), pool-RT-qPCRs tested positive with high viral loads (Ct-value $\leq 25)$ were observed 3.1-fold more often for the delta variant compared to the alpha variant (Fig. $\mathbf{4 b}$ and $4 \mathrm{c}$ ). Moreover, for viral loads detected with Ct-values $\leq 20$, the difference between alpha and delta was even 7.6fold.

In order to estimate a possible effect of the increase in pool-RT-qPCRs with low

Ct-values on infection dynamics, the increase in positive pool-RT-qPCRs containing more than one infected child was statistically modeled, using data from calendar weeks 19-25 (alpha period) and calendar weeks 34-37 (delta period). The numbers of infected children per positive pool-RT-qPCRs expected by chance and without in-class 201 transmissions (Null model) were estimated, while controlling for local incidence rates 202 and the SSDI, and compared to the observed number (Methods and Extended data 203 Fig. 8). During alpha- and delta periods, numbers of positive pool-RT-qPCRs 204 containing more than one infected child were 13 and 77, respectively, while 7.1 and 32 were expected based on the Null model (Fig. 4e). The ratio between observed and expected frequencies of pool-RT-qPCRs containing more than one infected child was 2071.8 for the alpha period and 2.4 for the delta period (Fig. 4f). This amounted to an 
medRxiv preprint doi: https://doi.org/10.1101/2022.02.04.22270304; this version posted February 6, 2022. The copyright holder for this preprint (which was not certified by peer review) is the author/funder, who has granted medRxiv a license to display the preprint in It is made available under a CC-BY-NC-ND 4.0 International license .

208 increase of $31 \%$ in positive pool-RT-qPCRs containing more than one infected child 209 during the delta period.

We concluded that, during the delta period, more children with higher viral loads

211 were present in schools and that parameters changing infection dynamics can be 212 detected by applying the Lolli-Method in schools.

\section{Discussion}

215 During the pandemic, schools have been frequently closed to reduce SARS-CoV-2 216 transmissions ${ }^{25}$. However, closure of schools and daycare facilities have had a 217 substantial impact on development, physical and mental health of children ${ }^{13-15,26}$. 218 Therefore, concepts are essential to support safe and open school settings. This is particularly important as new VOCs emerge that may substantially change infection dynamics.

Systematic testing can prevent transmissions in educational settings and gain

222 insights of measures for infection control in children ${ }^{18}$. In addition, effective test 223 strategies may allow to use NPIs more specifically and to reduce quarantine measures 224 to keep school absence of children to a minimum ${ }^{18}$. Effective screening strategies require an easy and non-invasive sample collection, high sensitivity assays for early detection of infections, and high-throughput application ${ }^{27}$. As one SARS-CoV-2 test 227 strategy, RADTs have been used ${ }^{28}$. While RADTs have the advantage of providing 228 immediate test results, disadvantages include limited sensitivity ${ }^{21}$, variation in 229 specimen quality ${ }^{29}$, and limited feasibility of self-sampling by young children. Finally, a 230 high acceptance was observed for sample collection based on the Lolli-Method as 231 demonstrated in a previous study 3 . 
medRxiv preprint doi: https://doi.org/10.1101/2022.02.04.22270304; this version posted February 6,2022 . The copyright holder for this preprint (which was not certified by peer review) is the author/funder, who has granted medRxiv a license to display the preprint in It is made available under a CC-BY-NC-ND 4.0 International license .

234 as well as gargling solutions and saliva samples were obtained. Some of these 235 sampling methods may cause difficulties, e.g. gargling solutions may increase the risk 236 of viral transmission during sampling because of aerosol generation. Moreover, 237 strategies that depend on sample-pooling in the diagnostic laboratory require 238 significantly more capacities in comparison of processing Lolli-swabs that have already 239 been pooled in schools ${ }^{32,33}$. Considering limited resources of RT-qPCR-capacities, the 240 Lolli-Method can therefore be advantageous as demonstrated by our report in which 241 less than 1.2 million RT-qPCRs were performed for investigating a total of 16.5 million swabs. However, high SARS-CoV-2 incidences yield larger numbers of positive pools 243 associated with increasing numbers of follow-up single RT-qPCRs, which reduces the 244 benefit of a pooling strategy and limit the application of pool-testing in high incidence 245 settings ${ }^{34}$.

There is an urgent medical need to determine the role and effect of NPIs in

247 educational settings, such as school-closures ${ }^{35}$, mandatory mask usage ${ }^{36}$, and split248 class lessons ${ }^{37}$. Notably, the described screening was sensitive enough to detect 249 biological differences of the infection dynamics between the alpha and the delta 250 variant ${ }^{38}$. Thus, the Lolli-Method may be further used to assess infection dynamics 251 introduced by new variants ${ }^{23}$ as well as determine the impact of measures taken in schools to prevent SARS-CoV-2 infections. Moreover, we could show a correlation between infection rates in schools and regional SARS-CoV-2 incidence which is in line 254 with previous studies $20,39$. Limitations of our report include aspects of the data quality. These contain i) reporting of the viral load as non-standardized Ct-values and ii) incomplete reporting of pool-sizes. However, there is a high level of consistency and comparability of Ctvalues since RT-qPCRs were performed by the same laboratories during the course of 259 the screening. In addition, due to the obligation for students to participate in the 
medRxiv preprint doi: https://doi.org/10.1101/2022.02.04.22270304; this version posted February 6, 2022. The copyright holder for this preprint (which was not certified by peer review) is the author/funder, who has granted medRxiv a license to display the preprint in It is made available under a CC-BY-NC-ND 4.0 International license .

screening program, we were able to estimate pool-sizes by extrapolation from reported data. One limitation of pool testing is that it is particularly suitable for low to medium SARS-CoV-2 incidences. For this reason, we consider it necessary to develop scalable modifications for the test concept for high-incidence phases (e.g. pool-size adjustment or additional use of RADTs).

In summary, we developed, validated and implemented a non-invasive and sensitive technique for SARS-CoV-2 (self)-sampling that can be used for highthroughput application and screening. We consider this sampling method applicable to schools and daycare facilities providing a reliable tool for screening and surveillance of SARS-CoV-2 infections in children.

Literature

272 1. Pavelka, M. et al. The impact of population-wide rapid antigen testing on SARS-CoV-2 prevalence in Slovakia. Science (80-. ). 372, 635-641 (2021).

2. Aiano, F. et al. Feasibility and acceptability of SARS-CoV-2 testing and surveillance in primary school children in England: Prospective, crosssectional study. PLoS One 16, e0255517 (2021).

277 3. Joachim, A. et al. Pooled RT-qPCR testing for SARS-CoV-2 surveillance in schools- a cluster randomised trial. EClinicalMedicine 39, 101082 (2021).

4. Vandenberg, O., Martiny, D., Rochas, O., van Belkum, A. \& Kozlakidis, Z. Considerations for diagnostic COVID-19 tests. Nat. Rev. Microbiol. Epub ahead, 1-13 (2021).

5. Volz E, Mishra S, Chand M, Barrett JC, Johnson R, Geidelberg L, Hinsley WR, Laydon DJ, Dabrera G, O’Toole Á, Amato R, Ragonnet-Cronin M, Harrison I, Jackson B, Ariani CV, Boyd O, Loman NJ, McCrone JT, Gonçalves S, 
medRxiv preprint doi: https://doi.org/10.1101/2022.02.04.22270304; this version posted February 6, 2022. The copyright holder for this preprint (which was not certified by peer review) is the author/funder, who has granted medRxiv a license to display the preprint in It is made available under a CC-BY-NC-ND 4.0 International license .

SARS-CoV-2 lineage B.1.1.7 in England. Nature 593, 266-269 (2021).

6. Christophers, B. et al. Trends in clinical presentation of children with COVID19: a systematic review of individual participant data. Pediatr. Res. 10, 1390020-01161-3 (2020).

7. Tagarro, A. et al. Screening and Severity of Coronavirus Disease 2019 (COVID-19) in Children in Madrid, Spain. JAMA Pediatr. e201346 (2020).

8. Ward, H. et al. SARS-CoV-2 antibody prevalence in England following the first peak of the pandemic. Nat. Commun. 4, 100098 (2021).

9. Say, D. et al. Post-acute COVID-19 outcomes in children with mild and asymptomatic disease. Lancet Child Adolesc. Heal. 5, e22-e23 (2021).

10. Jones, T. C. et al. Estimating infectiousness throughout SARS-CoV-2 infection course. Science (80-. ). 973, eabi5273 (2021).

11. Chu, V. T. et al. Household Transmission of SARS-CoV-2 from Children and

Adolescents. N. Engl. J. Med. 385, 954-956 (2021).

12. Covid 19 and School Closures: One Year of Education Disruption. Unicef (2021).

13. Hawrilenko, M., Kroshus, E., Tandon, P. \& Christakis, D. The Association between School Closures and Child Mental Health during COVID-19. JAMA Netw. Open 4, e2124092 (2021).

14. Lee, J. Mental health effects of school closures during COVID-19. Lancet Child Adolesc. Heal. 4, 421 (2020).

15. Monnier, M. et al. Children's mental and behavioral health, schooling, and socioeconomic characteristics during school closure in France due to COVID19: the SAPRIS project. Sci. Rep. 11, 1-15 (2021). 
medRxiv preprint doi: https://doi.org/10.1101/2022.02.04.22270304; this version posted February 6, 2022. The copyright holder for this preprint (which was not certified by peer review) is the author/funder, who has granted medRxiv a license to display the preprint in It is made available under a CC-BY-NC-ND 4.0 International license .

Eurosurveillance 25, 2001645 (2020).

313 17. Sherby, M. R. et al. SARS-CoV-2 screening testing in schools for children with intellectual and developmental disabilities. J. Neurodev. Disord. 13, 31 (2021).

18. Young, B. C. et al. Daily testing for contacts of individuals with SARS-CoV-2 infection and attendance and SARS-CoV-2 transmission in English secondary schools and colleges: an open-label, cluster-randomised trial. Lancet 398, 1217-1229 (2021).

19. Hoehl, S. et al. Longitudinal Testing for Respiratory and Gastrointestinal in Day Care Centers in Hesse, Germany. Clin. Infect. Dis. 73, e3036-e3041

20. Willeit, P. et al. Prevalence of RT-qPCR-detected SARS-CoV-2 infection at (2021). schools: First results from the Austrian School-SARS-CoV-2 prospective cohort

21. Corman, V. M. et al. Comparison of seven commercial SARS-CoV-2 rapid point-of-care antigen tests: a single-centre laboratory evaluation study. The Lancet Microbe 2, e311-e319 (2021).

22. Walter, E. B. et al. Evaluation of the BNT162b2 Covid-19 Vaccine in Children 5 to 11 Years of Age. N. Engl. J. Med. NEJMoa2116, (2021).

23. Karim, S. S. A. \& Karim, Q. A. Omicron SARS-CoV-2 variant: a new chapter in the COVID-19 pandemic. Lancet (London, England) 6736, 19-21 (2021).

24. Schräpler, J. \& Jeworutzki, S. Konstruktion des Sozialindex für Schulen in Nordrhein-Westfalen. (Zentrum für interdisziplinäre Regionalforschung (ZEFIR), Bochum, 2021). 
medRxiv preprint doi: https://doi.org/10.1101/2022.02.04.22270304; this version posted February 6, 2022. The copyright holder for this preprint (which was not certified by peer review) is the author/funder, who has granted medRxiv a license to display the preprint in It is made available under a CC-BY-NC-ND 4.0 International license .

338 25. Buonsenso, D. et al. Schools closures during the COVID-19 pandemic: A catastrophic global situation. Pediatr. Infect. Dis. J. e146-e150 (2021) doi:10.1097/INF.0000000000003052.

341 26. Ghosh, R., Dubey, M. J., Chatterjee, S. \& Dubey, S. Impact of COVID-19 on children: Special focus on the psychosocial aspect. Minerva Pediatr. 72, 226235 (2020).

27. Woloshin, S., Patel, N. \& Kesselheim, A. S. False Negative Tests for SARSCoV-2 Infection - Challenges and Implications. N. Engl. J. Med. (2020) doi:10.1056/nejmp2015897.

28. Hoehl, S. et al. At-home self-testing of teachers with a SARS-CoV-2 rapid antigen test to reduce potential transmissions in schools Results of the SAFE School Hesse Study. medRxiv (2020) doi:10.1101/2020.12.04.20243410.

29. Allan-Blitz, L. T. \& Klausner, J. D. A Real-World Comparison of SARS-CoV-2 Rapid Antigen Testing versus PCR Testing in Florida. J. Clin. Microbiol. 59, e01107-21 (2021)

30. Willeit, P. et al. Prevalence of RT-PCR-detected SARS-CoV-2 infection at schools: First results from the Austrian School-SARS-CoV-2 Study. medRxiv 2021.01.05.20248952 (2021) doi:10.1101/2021.01.05.20248952.

31. Mendoza, R. P. et al. Implementation of a pooled surveillance testing program for asymptomatic SARS-CoV-2 infections in K-12 schools and universities. EClinicalMedicine 38, 101028 (2021).

32. Goldfarb, D. M. et al. Self-collected saline gargle samples as an alternative to healthcare worker collected nasopharyngeal swabs for COVID-19 diagnosis in outpatients. medRxiv (2020) doi:10.1101/2020.09.13.20188334.

33. Wunsch, M. et al. Safe and Effective Pool Testing for SARS-CoV-2 Detection. 
medRxiv preprint doi: https://doi.org/10.1101/2022.02.04.22270304; this version posted February 6, 2022. The copyright holder for this preprint (which was not certified by peer review) is the author/funder, who has granted medRxiv a license to display the preprint in It is made available under a CC-BY-NC-ND 4.0 International license .

364

34. Wunsch, M. et al. Safe and effective pool testing for SARS-CoV-2 detection. $J$ Clin Virol 145, 105018 (2020).

35. Li, Y. et al. The temporal association of introducing and lifting nonpharmaceutical interventions with the time-varying reproduction number $(R)$ of SARS-CoV-2: a modelling study across 131 countries. Lancet Infect. Dis. (2020) doi:10.1016/S1473-3099(20)30785-4.

36. Lam-Hine, T. et al. Outbreak Associated with SARS-CoV-2 B.1.617.2 (Delta) Variant in an Elementary School — Marin County, California, May-June 2021. MMWR Recomm. Reports 70, 1214-1219 (2021).

37. Van Loon, W. et al. Prevalence of SARS-CoV-2 Infections among Students, Teachers, and Household Members during Lockdown and Split Classes in Berlin, Germany. JAMA Netw. Open 4, e2127168 (2021).

38. Campbell, F. et al. Increased transmissibility and global spread of SARS-CoV-2 variants of concern as at June 2021. Eurosurveillance 26, 2100509 (2021).

39. Ismail, S. A., Saliba, V., Lopez Bernal, J., Ramsay, M. E. \& Ladhani, S. N. SARS-CoV-2 infection and transmission in educational settings: a prospective, cross-sectional analysis of infection clusters and outbreaks in England. Lancet Infect. Dis. 21, 344-353 (2021).

40. Tovar, R. M., Gruell, H., Klein, F. \& Lässig, M. Stochasticity of infectious outbreaks and consequences for optimal interventions. (2021).

41. Quilty, B. J. et al. Quarantine and testing strategies in contact tracing for SARS-CoV-2: a modelling study. Lancet Public Heal. 6, e175-e183 (2021).

42. Walsh, K. A. et al. The duration of infectiousness of individuals infected with SARS-CoV-2. J. Infect. 81, 847-856 (2020).

43. Centers for Disease Control and Prevention. COVID-19 Pandemic Planning Scenarios. Centers Dis. Control Prev. (2021). 
medRxiv preprint doi: https://doi.org/10.1101/2022.02.04.22270304; this version posted February 6, 2022. The copyright holder for this preprint (which was not certified by peer review) is the author/funder, who has granted medRxiv a license to display the preprint in It is made available under a CC-BY-NC-ND 4.0 International license .

390

391

392

393

394

395

396

397

398

399

400

401

402

403

404

405

406

407

408

409

410

411

412

413

414

415

44. Davies, N. G. et al. Estimated transmissibility and impact of SARS-CoV-2 lineage B.1.1.7 in England. Science (80-. ). 372, eabg3055 (2021).

45. Alcoba-Florez, J. et al. Sensitivity of different RT-qPCR solutions for SARSCoV-2 detection. Int. J. Infect. Dis. 99, 190-192 (2020).

46. Kucirka, L. M., Lauer, S. A., Laeyendecker, O., Boon, D. \& Lessler, J. Variation in False-Negative Rate of Reverse Transcriptase Polymerase Chain ReactionBased SARS-CoV-2 Tests by Time Since Exposure. Ann. Intern. Med. 173, 262-267 (2020).

47. Vogels, C. B. F. et al. Analytical sensitivity and efficiency comparisons of SARS-CoV-2 RT-qPCR primer-probe sets. Nat. Microbiol. 5, 1299-1305 (2020).

48. Goyal, A., Reeves, D. B., Fabian Cardozo-Ojeda, E., Schiffer, J. T. \& Mayer, B. T. Viral load and contact heterogeneity predict sars-cov-2 transmission and super-spreading events. Elife 10, e63537 (2021).

\section{Methods}

\section{Ethical considerations}

Prospective Validation of the Lolli-Method

The prospective validation study was approved by the ethics committee of the Faculty of Medicine and University Hospital of Cologne, Cologne, Germany (number 20-1405) as well as by the ethics committee of the High Specialty Regional, Villahermosa, Mexico (number 0130144). The participants were either study patients of the University Hospital Cologne, Germany or of the test center of the High Specialty Regional Hospital, Villahermosa, Tabasco, Mexico. All participants gave their written informed consent before the start of the study. 
medRxiv preprint doi: https://doi.org/10.1101/2022.02.04.22270304; this version posted February 6,2022 . The copyright holder for this preprint (which was not certified by peer review) is the author/funder, who has granted medRxiv a license to display the preprint in It is made available under a CC-BY-NC-ND 4.0 International license .

416 Retrospective analysis of the SARS-CoV-2 screening in schools

417 The retrospective analysis of the SARS-CoV-2 screening in schools by the University

418 Hospital of Cologne was engaged by the Ministry of Education and Schools and

419 approved by the ethics committee of the Faculty of Medicine, University Hospital of

420 Cologne, Germany (number 21-1358). Since $10^{\text {th }}$ of May 2021, under the direction of

421 the Ministry of Schools and Education and as part of the governmental SARS-CoV-2

422 screening program "Lolli-Test NRW", two Lolli-tests per week combined with a pooled

423 RT-qPCR analysis were mandatory for all students at elementary schools and special

424 needs schools in the state of North Rhine-Westphalia. 12 diagnostic laboratories were

425 involved in processing the Lolli-swabs. These laboratories transmitted anonymized, de-

426 identifiable data to a digital database (Medeora Köln $\mathrm{GmbH}$ ) for quality assurance

427 purposes. Data were transmitted for pool-RT-qPCRs and single RT-qPCRs. For pool-

428 RT-qPCRs, date of sampling, time of registration and result communication, the name

429 of the school, the name of the class, the number of students per pool and the test result

430 were transmitted. For single-RT-qPCRs, date of sampling, time of registration and

431 result communication, the name of the school, the name of the class, age, gender and

432 the test result were transmitted. From the digital database, data were transmitted to

433 the University Hospital Cologne for retrospective analysis.

435 Retrospective analysis of the SARS-CoV-2 screening in daycare facilities

436 For retrospective analysis of the SARS-CoV-2 screening in daycare facilities, the

437 University of Cologne was engaged by the Youth Welfare Office of the city of Cologne

438 and approved by the ethics committee of the Faculty of Medicine, University Hospital

439 of Cologne, Germany (number $21-1358$ ). Since $15^{\text {th }}$ of March 2021, voluntary SARS-

440 CoV-2 testing was offered to all daycare facilities in Cologne within the SARS-CoV-2

441 screening program "Kita Testung Köln (KiKo)" under the direction of the Youth Welfare 
medRxiv preprint doi: https://doi.org/10.1101/2022.02.04.22270304; this version posted February 6, 2022. The copyright holder for this preprint (which was not certified by peer review) is the author/funder, who has granted medRxiv a license to display the preprint in It is made available under a CC-BY-NC-ND 4.0 International license .

442 Office of the city of Cologne. Of all participating children and staff members, two Lolli-

443 Swabs per week were tested in a pooled RT-qPCR. One diagnostic laboratory was

444 involved in processing the Lolli-swabs. This laboratory transmitted anonymized, de-

445 identifiable data to the University Hospital of Cologne for retrospective analysis weekly.

446 Data were transmitted for pool-RT-qPCRs and single RT-qPCRs. For pool-RT-qPCRs,

447 date of sampling, time of registration and result communication, the name of the 448 daycare facility, the name of the group, the number of individuals per pool and the test 449 result were transmitted. For single-RT-qPCRs, date of sampling, time of registration 450 and result communication, the name of the daycare facility, the name of the group, 451 age, gender and the test result were transmitted.

453 Instructions for the SARS-CoV-2 screenings in schools and daycare facilities

454 All staff, parents and children were instructed by either the Ministry of Education and 455 Schools of North Rhine-Westphalia or the Youth Welfare Office of the city of Cologne. 456 Written instructions in 12 different languages as well as instructional videos were used 457 for training of all involved individuals. In addition, information and instructions for 458 parents, children and staff were made available online 459 (https://www.schulministerium.nrw/lolli-tests, https://www.kita-testung-koeln.de)

\section{Sample processing}

\section{Validation of the Lolli-Method}

463 To determine the sensitivity of the Lolli-Method, matched Lolli-swabs and Np/Op464 swabs of acutely infected individuals were obtained. The participants were instructed 465 to suck on a regular swab it for 30 seconds. Very young children were supported by 466 either their parents or a physician. Afterwards, a physician took an Np-/Op-swab. 
medRxiv preprint doi: https://doi.org/10.1101/2022.02.04.22270304; this version posted February 6,2022 . The copyright holder for this preprint (which was not certified by peer review) is the author/funder, who has granted medRxiv a license to display the preprint in It is made available under a CC-BY-NC-ND 4.0 International license .

To find out, whether the time of day at which the samples were taken had an

468 impact on the sensitivity, the individuals were sampled either in the morning, one hour

469 after breakfast or at any time of the day. The impact of the pooling process on the

470 measured viral loads was determined by obtaining two Lolli-swabs from the same

471 participant at the same time. One sample was tested in a pool-RT-qPCR with up to 17,

47249 or 99 negative samples and the corresponding sample was tested in a single-RT-

473 qPCR. To determine whether the detection rate depends on a particular swab type that

474 is used for the sampling, the following four types of swabs were used for sample

475 collection of Lolli-swabs: A) Oropharyngeal swab, Copan, catalog number: 801U059,

476 B) Nasopharyngeal swab, Biocomma, catalog number: YVJ-TE4, C) Oropharyngeal

477 swab, Biocomma, catalog number: YVJ-TE4, D) Dry swab, Sarstedt, catalog number: 4781 U059S01.

When tested in a single-RT-qPCR, each Lolli-swab was placed in a $2 \mathrm{ml}$ tube 480 pre-filled with $2 \mathrm{ml}$ phosphate buffered saline (PBS), moved up and down and pressed 481 against the bottom of the tube repetitively for 20 seconds. The Np/Op-swabs were 482 vortexed in the viral transport media for 20 seconds. When tested in a pool-RT-qPCR, 483 a Lolli-swab of one acutely infected individual was tested in a pool with 17, 49 or 99 484 Lolli-swabs of individuals not infected with SARS-CoV-2. A pool of Lolli-swabs was processed by placing the Lolli-swabs in one $50 \mathrm{ml}$ centrifugation tube, adding $3 \mathrm{ml}$ PBS and vortexing for 30 seconds. Of all samples, $1 \mathrm{ml}$ each was used for SARS-CoV-2 487 detection.

SARS-CoV-2 screening in schools and daycare facilities

490 Lolli-swabs were used as described above for the sampling of the students in schools 491 and children and the staff in daycare facilities. The staff was instructed for self-sampling 492 and supervising of the sampling of the children. The samples of all participants of the 
medRxiv preprint doi: https://doi.org/10.1101/2022.02.04.22270304; this version posted February 6, 2022. The copyright holder for this preprint (which was not certified by peer review) is the author/funder, who has granted medRxiv a license to display the preprint in It is made available under a CC-BY-NC-ND 4.0 International license .

493 same daycare group or school class were placed in one $50 \mathrm{ml}$ centrifugation tube

494 (Supplementary Videos 1 and 2) and transported to one of the 12 diagnostic 495 laboratories. $3 \mathrm{ml}$ PBS were pipetted in one centrifugation tube. The tube was vortexed 496 for 30 seconds.

498 SARS-CoV-2 detection and quantification

499 Validation of the Lolli-Method

500 For SARS-CoV-2 detection, either COBAS 6800 (Roche Diagnostics) and Alinity m 501 (Abbott) instruments equipped with their respective SARS-CoV-2 detection kits, or the 502 Quantstudio 5 (Thermofisher) instrument, using the Quick-RNA Viral Kits (Zymo 503 Research) for RNA isolation and GeneFinder ${ }^{\text {TM }}$ COVID-19 Plus RealAmp was used.

504 For the comparison of cycle threshold (Ct) values measured by the different RT-qPCR 505 equipments, Ct-values were translated into copies/ml. To this end, seven serial 506 dilutions from a high titer SARS-CoV-2 sample were tested in all RT-qPCR equipments 507 described above. With help of a regression model, standard curves for each equipment 508 were generated. For the following conversion of device-specific Ct-values into 509 copies/ml, two SARS-CoV-2 samples with a quantified RNA load from INSTAND 510 (Society for the Promotion of Quality Assurance in Medical Laboratories, e.V.,

511 Düsseldorf, Germany; in cooperation with the Robert Koch-Institute and the Institute of 512 Virology, Charité, Berlin) were tested on every device and subsequently used for Ct513 based absolute RNA quantification.

SARS-CoV-2 screening in schools and daycare facilities

516 For SARS-CoV-2 detection, the 12 laboratories reported to use different equipment

517 which is listed in Supplementary Table 1. Viral load was reported as Ct-value. 
medRxiv preprint doi: https://doi.org/10.1101/2022.02.04.22270304; this version posted February $6,2022$. The copyright holder for this preprint (which was not certified by peer review) is the author/funder, who has granted medRxiv a license to display the preprint in It is made available under a CC-BY-NC-ND 4.0 International license .

\section{Adapting the SIR-Model to a SARS-CoV-2 screening of children}

520 A compartmental epidemiological model was used to study the efficiency of a long521 term SARS-CoV-2 screening based on the Lolli-Method. The model consists of a 522 closed population of $N$ individuals and four possible states for each of them: 523 Susceptible (S), pre-infectious (P), infectious (I) and recovered (R) (Figure 1i). Those

524 states were chosen based on the impact that a long pre-infectiousness period has on 525 the epidemiological dynamics and on testing-based non-pharmaceutical 526 interventions ${ }^{40}$.

527 Susceptible individuals get infected by a transmission within the population 528 (internal infection rate) or by an exogenous transmission from outside the population 529 (external infection rate), at rates $r_{1}$ and $r_{2}$ respectively. Overall, the total infection rate 530 of susceptible individuals is given by

$$
r=a r_{1}+(1-a) r_{2}
$$

532 where $a$ is the fraction of time that individuals interact within the population. $a=5 / 7$

533 was chosen in order to approximate interactions within the population only occurring 534 during weekdays. The internal infection rate is defined as

$$
r_{1}=\frac{\beta I}{N}
$$

536 and the external infection rate as

$$
r_{2}=\beta \pi
$$

538 where $I$ is the total number of infectious individuals in the population, $\pi$ is the global 539 prevalence and $\beta$ is the infection-causing contact rate between individuals.

540 An infected individual that is in the pre-infectious state moves into the infectious state 541 at a constant rate of $r_{p}$ :

$$
r_{p}=\frac{1}{\tau_{p}}
$$


medRxiv preprint doi: https://doi.org/10.1101/2022.02.04.22270304; this version posted February $6,2022$. The copyright holder for this

preprint (which was not certified by peer review) is the author/funder, who has granted medRxiv a license to display the preprint in It is made available under a CC-BY-NC-ND 4.0 International license.

543 From the infectious state, an infected individual moves to the recovered state at a

544 constant rate of $r_{i}$ :

$$
r_{i}=\frac{1}{\tau_{i}}
$$

546 These two last stochastic transitions follow homogeneous Poisson processes and 547 therefore, pre-infectious and infectious periods in the population follow exponential 548 distributions with corresponding means $\tau_{p}$ and $\tau_{i}$.

Implementing the sensitivity of the Lolli-Method in the extended SIR-model

551 The probability of a positive test result when testing an infected individual is $p_{\text {det }}$ given 552 by

$$
p_{\text {det }}=p_{P C R} \times S(V L)
$$

554 where $1-p_{P C R}$ is the false-negative rate of RT-qPCR and $S(V L)$ is a viral load 555 dependent function of sensitivity. To estimate $S(V L)$, we fit the measured sensitivity 556 data to a sigmoidal function given by

$$
S(V L)=\frac{1}{1+\left(\frac{\log _{10} V L}{\log _{10} V L_{50}}\right)^{-\delta}}
$$

558 where $V L_{50}$ and $\delta$ are fit parameters. $V L_{50}$ corresponds to the viral load at which $559 S\left(V L_{50}\right)=0.5$ and $\delta$ quantifies the steepness of the sigmoidal function.In order to 560 determine the time dependence of the sensitivity of the Lolli-Method (days since 561 infection), it was assumed that infected individuals would have a viral load of $10^{6}$ 562 copies/ml three days after infection. An exponentially increasing viral load $V L(t)$ 563 defined the dynamics of the viral load of infected individuals:

$$
V L(t)=e^{g t}
$$

565 Temporal dynamics of viral load and the associated sensitivity of the Lolli-Method are 566 relevant because it was assumed that infectiousness would begin three days after 
medRxiv preprint doi: https://doi.org/10.1101/2022.02.04.22270304; this version posted February 6, 2022. The copyright holder for this preprint (which was not certified by peer review) is the author/funder, who has granted medRxiv a license to display the preprint in It is made available under a CC-BY-NC-ND 4.0 International license .

567 infection (Fig. 1j). Thus, in this model, transmissions within the institutions can only

568 take place when the infection occurred at least three days ago. Infected individuals

569 would be infectious on average for 6 days. A summary of model inputs can be found

570 in Extended data Table 2,38,41-48.

571 The numerical dynamics consist of continuous-time and individual-based

572 simulations, in which the transitions between states of each individual are

573 stochastically determined using the Gillespie algorithm. Additionally, a testing scheme

574 was implemented in which infected individuals were tested positive according to

$575 p_{\text {det }}(t)$. Detected individuals were removed from the interacting population and the rest

576 of the population was quarantined for the next 14 days. After this period, individuals

577 could interact again. In this way, infected individuals that were not tested positive could

578 transit to a recovered state $(R)$ without infecting other individuals in the test-population.

\section{Calculation of 7-day pool incidence in schools}

581 Pool-sizes were estimated by a linear model using official data by the Ministry of

582 Schools and Education of North Rhine-Westphalia on class sizes and available

583 reported pool-sizes (Extended data Fig. 9a). During the first three weeks of the

584 screening, students were taught and tested in a split-class lesson model, while a full-

585 class lesson model was the basis of lessons and testing for the rest of the screening.

586 During split-class lessons, $50 \%$ of the students of one class attended lessons and were

587 tested on Mondays and Wednesdays. The other $50 \%$ of the students attended lessons

588 and were tested on Tuesdays and Thursdays. During full-class lessons, the whole

589 class attended lessons daily and was tested either Mondays and Wednesdays or

590 Tuesdays and Thursdays (Extended data Fig. 9b). Pool sizes were reported by the

591 tested schools (Extended data Fig. 9c). Means of class-sizes per school and means

592 of reported pool-sizes per school were mapped as part of a linear model with a forced 
medRxiv preprint doi: https://doi.org/10.1101/2022.02.04.22270304; this version posted February 6,2022 . The copyright holder for this preprint (which was not certified by peer review) is the author/funder, who has granted medRxiv a license to display the preprint in It is made available under a CC-BY-NC-ND 4.0 International license .

593 Y-axis intercept of 0. (Extended data Fig. 9d) Slopes during spit-class lessons were

$594 \mathrm{~m}=0.97$ and during full-class lessons $\mathrm{m}=0.97$ before and 0.96 after summer holidays.

595 Thus, reported average pool-sizes per school corresponded to approximately $97 \%$ and

$59696 \%$, respectively, of the average class-sizes per school. For this reason, average

597 class-sizes per school were used as an estimate of the average pool-sizes per school

598 for the estimation of number of children tested and the subsequently calculated 7-days-

599 pool-incidence $($ pool-incidence $=$ number of positive pool-RT-qPCRs $/ 100.000$ tested 600 children in 7 days)

601

602 School social deprivation index (SSDI)

603 The level of social deprivation of schools is measured by a nine-level school social 604 deprivation index (SSDI). The index is generated via a confirmatory factor analysis with 605 four indicator variables ${ }^{24}$. The latent variable is divided into nine classes: Level 1 corresponds to a very low social deprivation; level 9 corresponds to a very high social

607 deprivation. The index is based on several school-related indicators:

608 1. Child and youth poverty in the vicinity of an elementary school

6092 2. Proportion of students with predominantly non-German family languages

$6103 . \quad$ Proportion of students who have moved to Germany from abroad

6114 Proportion of students with special educational needs for learning, emotional 612 and social development and language

613 The selection of the indicators is based on two criteria: First, to reflect socio-

614 demographic variables relevant to school performance, and second, to avoid additional

615 data collection and to use data that are uniformly available across the state.

616 With the exception of the indicator for child and youth poverty, all data come from the

617 official school statistics of the state of North Rhine-Westphalia. A kernel-density 618 estimate for the residential addresses of minors in unemployment/social-assitance- 
medRxiv preprint doi: https://doi.org/10.1101/2022.02.04.22270304; this version posted February 6,2022 . The copyright holder for this preprint (which was not certified by peer review) is the author/funder, who has granted medRxiv a license to display the preprint in It is made available under a CC-BY-NC-ND 4.0 International license .

619 beneficiary households from the statistics of the Federal Employment Agency forms

620 the indicator for child and youth poverty. It is a location statistic that shows the spatial

621 density of minors in the vicinity of schools. The fourth indicator is included in the model

622 as an interaction indicator (indicator of child and youth poverty * proportion of students

623 with special educational needs). Therefore, a correlation between the interaction

624 indicator and the indicator for children and youth poverty was allowed in the factor 625 model.

The index shows good explanatory power for different learning outcomes when evaluated with the results of the centrally organized performance assessments VERA 3 (e.g. correlation with reading comprehension in German results in $R^{\wedge} 2=0.39$ ).

\section{SARS-CoV-2 infection dynamics in schools}

631 Estimating the differences between SARS-CoV-2 variants in infection dynamics in schools was based on the notion that transmissions inside school classes (in-class transmissions) should lead to an excessive number of pool-RT-qPCRs containing more

634 than one infected child. We implemented this notion by first estimating the expected 635 number of pool-RT-qPCRs with more than one infected child assuming a Null model without in-class transmissions. We next compared the expected number of pool-RT637 qPCRs with more than one infected child to the observed number of pool-RT-qPCRs with more than one infected child.

Positive pool-RT-qPCRs were filtered based on the following criteria to ensure 640 only high-quality data is used for this analysis: i) only pool-RT-qPCRs that have a 641 matching positive single-RT-qPCR, ii) number of following single-RT-qPCRs is within $64220 \%$ of the pool size.

643 First, we calculated the probability of each tested child being infected under the 644 Null model. To calculate the probability of each tested child being infected, we fitted a 
medRxiv preprint doi: https://doi.org/10.1101/2022.02.04.22270304; this version posted February 6 , 2022. The copyright holder for this preprint (which was not certified by peer review) is the author/funder, who has granted medRxiv a license to display the preprint in It is made available under a CC-BY-NC-ND 4.0 International license .

645 single linear model for the entire testing period (calendar week 19-25, 34-37) using the

646 local (district level) 7-day incidence of children aged between 6 and 10 years, the rate

647 of positivity of pool-RT-qPCRs per district and per calendar week and the school social

648 deprivation index (SSDI) as predictors (covariates),

$$
p\left(P_{i w}\right)=p_{i w}=\beta_{1} \cdot I_{i w}+\beta_{2} \cdot P R_{i w}+\beta_{3} \cdot S S D I_{i}+\beta_{4} \cdot I_{i w} S S D I_{i}+\beta_{5} \cdot P R_{i w} S S D I_{i}
$$

650 where $P_{i w}$ is the event that a specific child in a positive pool-RT-qPCR in school $i$ and 651 week $w$ is tested positive, $p_{i w}$ is the probability of being infected per child, $I_{i w}$ is the local

652 7-day incidence among children aged between 6 and 10 years, $P R_{i w}$ is the rate of 653 positivity of pool-RT-qPCRs per district and per calendar week $w, S S D I_{i}$ is the school 654 social deprivation index of school $i$ and $\beta_{1-5}$ are the regression coefficients. The $y$ 655 offset was set to zero (i.e. if the incidence is zero no children can get infected).

656 After fitting the above regression coefficients, we calculated the probability of being 657 infected per child $p_{i w}$ for each positive pool RT-qPCR. Each such pool contains at least 658 one infected child by definition. We computed the probability of observing additional 659 infected children assuming a binomial distribution,

$$
P(X)=\frac{n}{k} \cdot p_{i w}^{k} \cdot\left(1-p_{i w}\right)^{n-k}
$$

661 where $p_{i w}$ is the probability of each child being infected derived from the linear model 662 above, $n$ is the number of tested children in a pool-RT-qPCR and $k$ is the number of 663 additional infected children. Using this binomial distribution, we computed the expected

664 number of pool-RT-qPCRs with more than one infected child under the Null model (i.e. 665 assuming no in-class transmissions). These values were compared to the observed number of pool-RT-qPCRs with more than one infected child in a given time period. 
medRxiv preprint doi: https://doi.org/10.1101/2022.02.04.22270304; this version posted February $6,2022$. The copyright holder for this preprint (which was not certified by peer review) is the author/funder, who has granted medRxiv a license to display the preprint in It is made available under a CC-BY-NC-ND 4.0 International license .

\section{Statistical analysis}

671 Geometric means were calculated for viral loads. Differences in viral loads were 672 calculated with Wilcoxon-signed rank test (WSR) and Friedman test (FT). P-values $673<0.05$ were considered significant. Sensitivity (positive percent agreement) and 674 specificity (negative percent agreement) were calculated using RT-qPCR agreement. 675 Differences in Ct-values during the screening program were calculated with Mann676 Whitney test (MWT). Data analyses were done using the software GraphPad Prism 677 (v.9), Microsoft Excel for Mac (v.14.7.3.) and R programing language (v. 3.5.2, stats 678 package).

Additional Software

681 Maps of North Rhine-Westphalia and Cologne were designed with the iMapU tool provided by iExcelU. Codes used of the epidemiological simulations are available in the Github repository https://github.com/betoto008/lolli_testing.

\section{Data availability}

686 All data used in this analysis can be made available upon request.

\section{Acknowledgements}

689 We thank all participiants of the validation of the Lolli-Method and all children and staff 690 in tested daycare facilities and schools. We thank Sascha Nickel and Anne Fries as 691 well all staff members of their daycare facilities for their impetus for the development 692 of the Lolli-Method. We thank all members of the Institute of Virology, University 693 Hospital Cologne. In particular, we thank Irina Fish, Ivonne Torre-Lage, Christina 694 Hellriegel and Esther Milz for processing of SARS-CoV-2 samples and optimizing the 695 logistics. We thank Carsten Tschirner (IExcelU) for supporting data vizualisation, 
medRxiv preprint doi: https://doi.org/10.1101/2022.02.04.22270304; this version posted February 6, 2022. The copyright holder for this preprint (which was not certified by peer review) is the author/funder, who has granted medRxiv a license to display the preprint in It is made available under a CC-BY-NC-ND 4.0 International license .

696 Stephan Glaremin, Udo Neumann, Anja Kolb-Bastigkeit (Amt für Jugend, Arbeit und 697 Soziales der Stadt Köln), Barbara Michaelis, Niklas Marizy (Gesundheitsamt Köln) for 698 administrative support during implementation of the screening in Cologne. We thank 699 Janna Seifried and Sindy Böttcher (Robert Koch Institute) for continuous support and 700 discussions, Norbert Schmeißer and Frederik Schmeißer (Medeora GmbH Köln) for 701 supporting data collection, Kim Zun-Gon, Florian Korte and Hendrik Schöneborn 702 (Boston Consulting Group) for organizational support, Christoph Gusovius from the Ministry for Schools and Education of the State of North Rhine-Westphalia, and Dietmar Klimas and Philip Graul (Labor ZotzKlimas, Düsseldorf, Germany) and Philipp Kirfel (Synlab) for supporting diagnostic analysis.

706

707

708

709

710

711

712

713

714

715

716

717 final manuscript

\section{Author contributions}

All authors contributed to sections relevant to their experience. F.D., F.K., R.K., I.S., G.F., A.B. and J.R. contributed to conception and design of the project. F.D. G.H.Q., R.K., F.K., V.D.C., G.B.F., D.L.V., A.R.H., J.M.C., A.T.H., J.R.Q., K.S., M.M., J.C.L., C.H., L.T.W., E.H., E.K. and M.W. developed and validated the Lolli-Method. R.M.T. and M.L. developed the extension of the SIR-model. G.Q., H.W., C.T., R.Z., H.J., A.P., I.H., P.C., F.J.S., P.P., G.K., C.K. performed RT-qPCRs during the screening programs. M.B., A.W., A.K., J.N. and A.L. partnered as public health scientists. F.D., R.J., J.G, G.S., F.B., J.K., A.K., C.G. and M.F. performed data analysis. M.H., J.P.S. and J.G. performed statistical analysis. F.D., L.J., and V.L. managed the administrative framework. F.K., G.F., A.B. and J.D. supervised the project. F.D., R.M.T., J.G., R.J. S.J. and J.P.S. wrote the draft manuscript. All authors were involved in editing of the 
medRxiv preprint doi: https://doi.org/10.1101/2022.02.04.22270304; this version posted February 6 , 2022. The copyright holder for this

preprint (which was not certified by peer review) is the author/funder, who has granted medRxiv a license to display the preprint in It is made available under a CC-BY-NC-ND 4.0 International license .

\section{Competing interest declaration}

723 The authors have no competing interests. F.D., F.K. and R.K. hold EU-wide trademark

724 protection for the terms "Lolli-Test" (018503959) and "Lolli-Methode" (018503958).

725

726 Additional Information

727 Supplementary Information is available for this paper.

728 Correspondence should be addressed to florian.klein@uk-koeln.de

729 Funding was provided by the German Ministry of Education and Research (BMBF)

730 (registration number: 01KX2021) within Bundesweites Forschungsnetz „Angewandte

731 Surveillance und Testung“ (B-FAST) project of the „NaFoUniMedCovid19“ consortium.

732 Furthermore, funding was provided by the state of North Rhine-Westphalia and by the

733 Bundesministerium für Bildung und Forschung (registration number: ZMl1-

734 2521COR004). 
medRxiv preprint doi: https://doi.org/10.1101/2022.02.04.22270304; this version posted February 6, 2022. The copyright holder for this preprint (which was not certified by peer review) is the author/funder, who has granted medRxiv a license to display the preprint in It is made available under a CC-BY-NC-ND 4.0 International license .

a

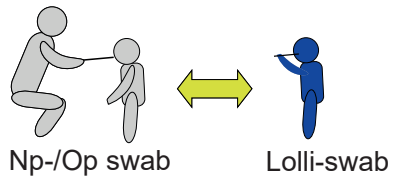

Side by side sample-collection SARS-CoV-2-infected indiviuals $(n=276)$

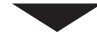

RT-qPCR b

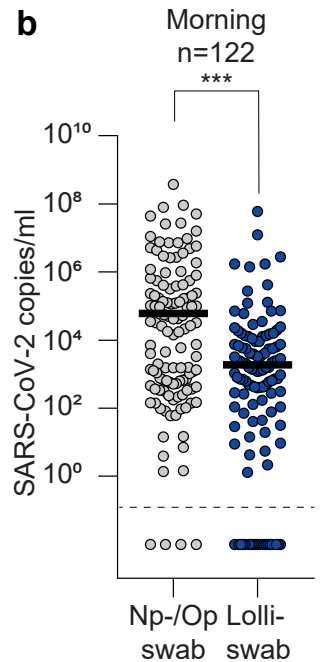

C

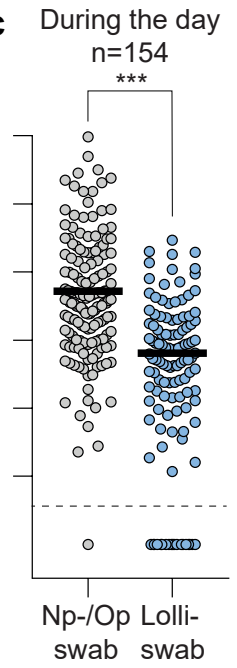

d Sensitivity of the Lolli-Method
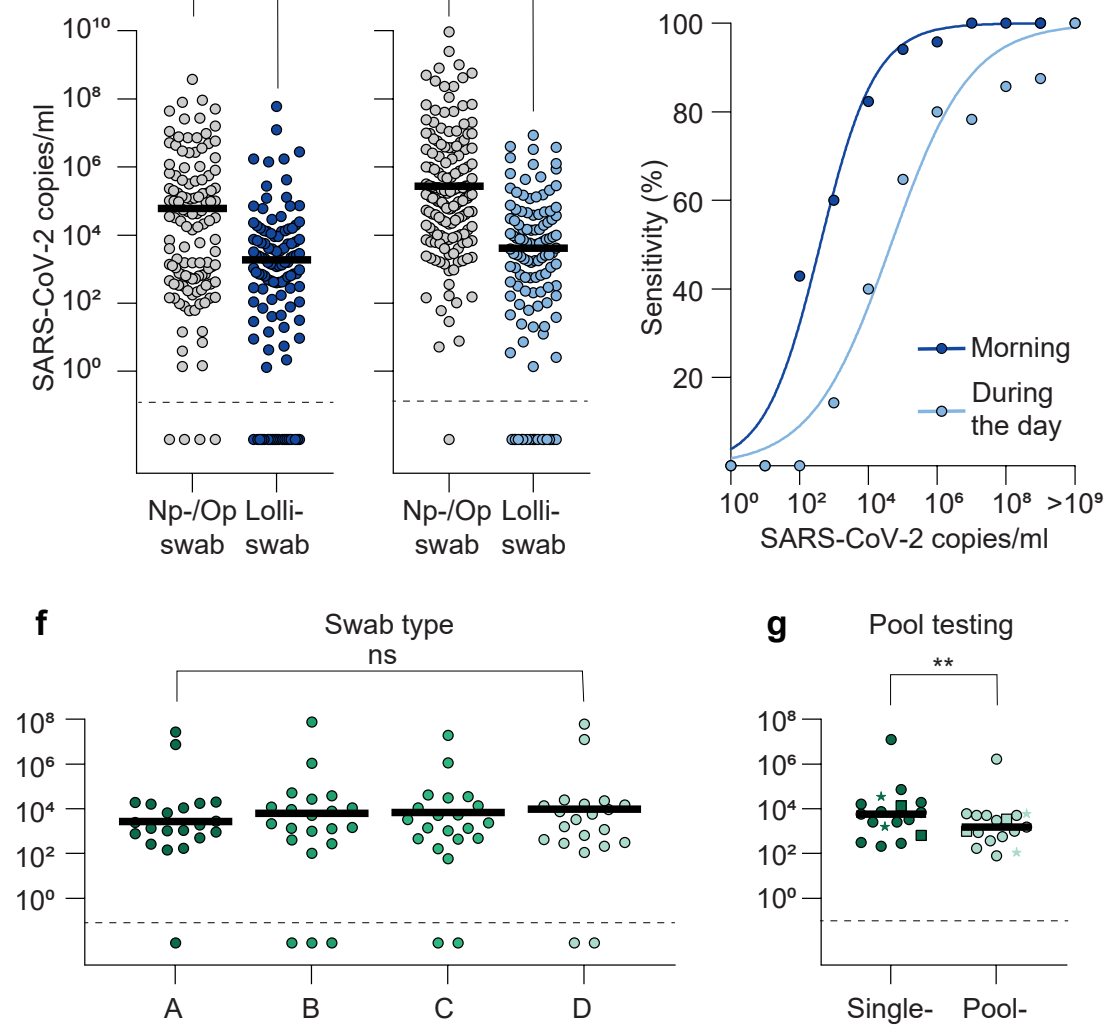

g Pool testing

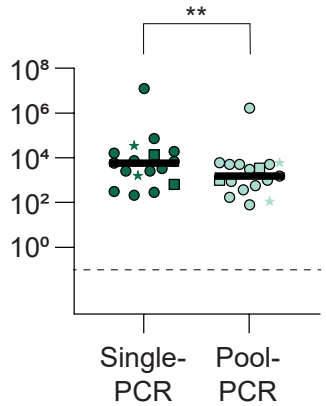

h

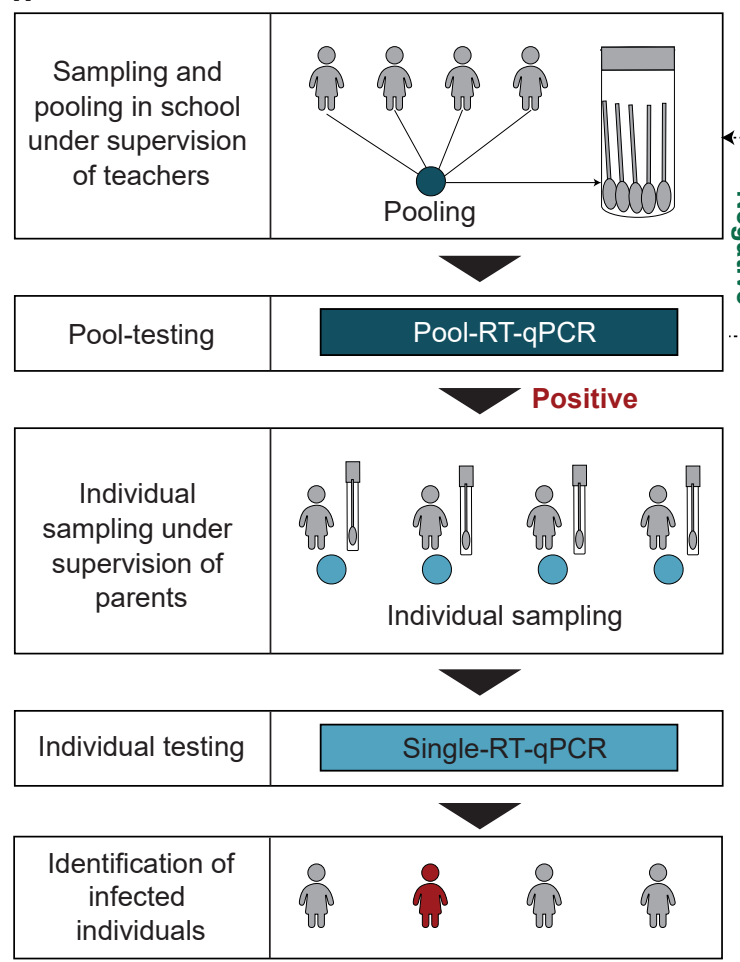

i
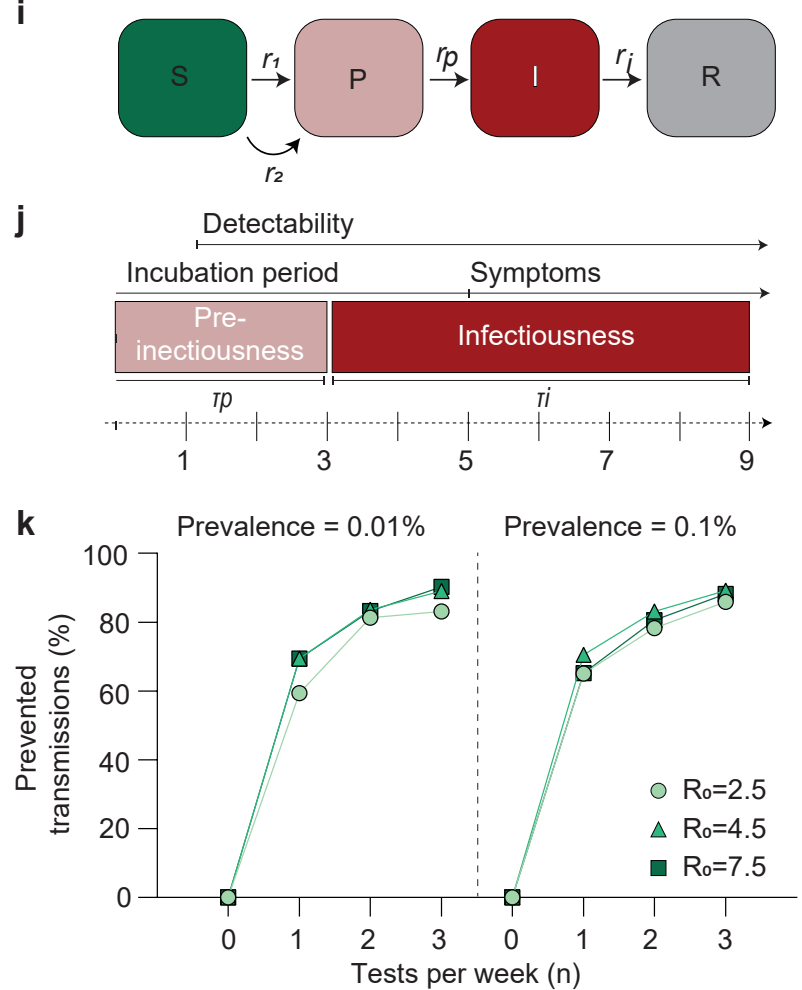

Fig. 1: Lolli-Method for high-throughput SARS-CoV-2 screening in children

a, Experimental design used to validate the Lolli-Method. b, Np-/Op-swabs and Lolli-swabs obtained in the morning plotted by viral load ( $p<0.0001$, WSR). c, Np-/Op-swabs and Lolli-swabs obtained during the day plotted by viral load $(p<0.0001, W S R)$. $\mathbf{d}$, The sensitivity of the Lolli-Method is stratified by viral load. Time of sampling is indicated in corresponding colors. e-g, Matched Lolli-Swabs plotted by viral loads obtained in the morning and 1 hour after breakfast (e), with four types of Lolli-swabs (f), and for single-and pool-RT-qPCR, respectively (g). $\mathbf{g}$, Dots represent pools of 18 , squares of 49 and stars of 100 individuals. $\mathbf{h}$, Visualization of the screening concept. Samples are pooled in the classroom and tested in RT-qPCR. Individual RT-qPCRs are tested the next day and only in case of a positive pool. i, Extension of the SIR-model to determine efficiency of the screening program. $\mathbf{j}$, Assumptions for the course of a SARS-CoV-2 infection. $\mathbf{k}$, Fractions of prevented transmissions stratified by test-frequency. Dots, triangles and squares represent SARS-CoV-2 basic reproduction values of 2.5, 4.5 and 7.5. 
medRxiv preprint doi: https://doi.org/10.1101/2022.02.04.22270304; this version posted February 6, 2022. The copyright holder for this preprint (which was not certified by peer review) is the author/funder, who has granted medRxiv a license to display the preprint in

It is made available under a CC-BY-NC-ND 4.0 International license .

a

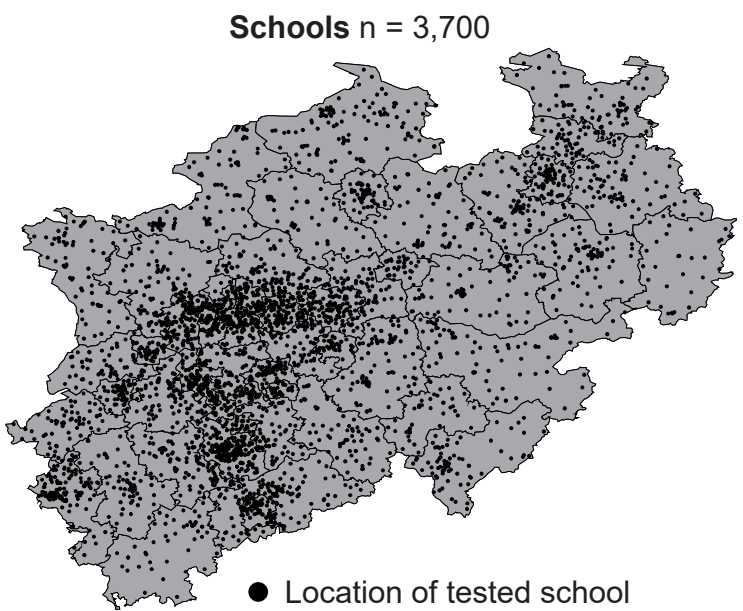

c

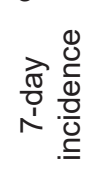

7-day incidence and VOCs in NRW

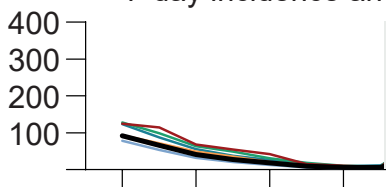

- All age groups $-0-5$ years

$-11-18$ years $-19-29$ years $->29$ years

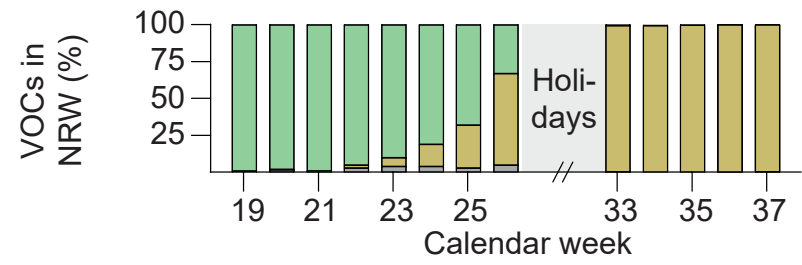

$\square$ Alpha $\square$ Delta $\square$ Other
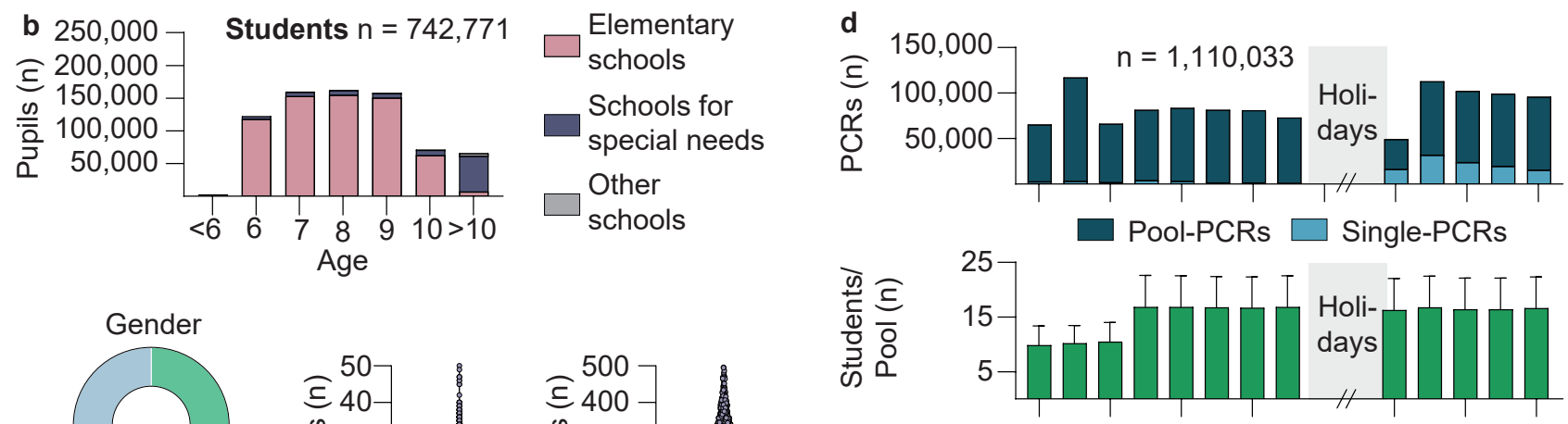

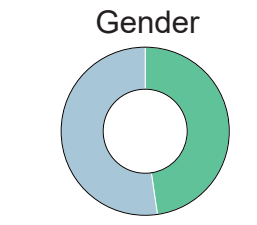

Female $(47.69 \%)$

Male $(52.32 \%)$

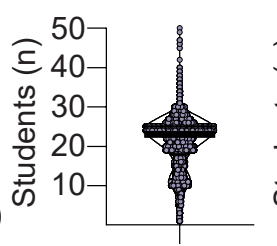

Students/class

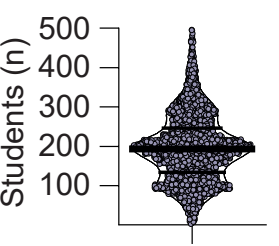

Students/school

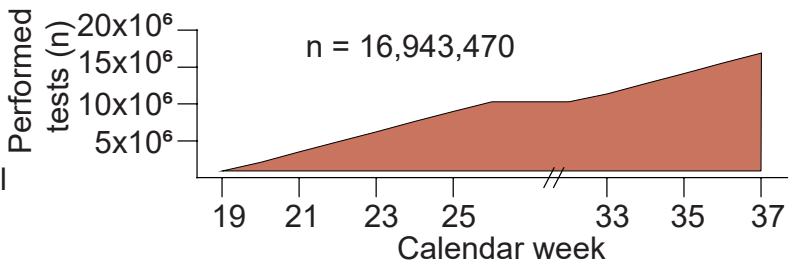

Fig. 2: Implementing the Lolli-Method screening concept in schools and daycare facilities

a, Map of North Rhine-Westphalia. Black dots mark the location of each school. b. Epidemiological characteristics of the tested students and characteristics of schools. Black horizontal lines in the violin plots represent median, first and third quartile. c, 7-day incidence of different age groups (top) and frequency of variants of concern according to data published by the Robert Koch Institute (bottom) stratified by calendar week. Summer holidays are marked in grey. d, Number of performed RT-qPCRs (blue), average pool-sizes (green) and total number of performed tests are stratified by calendar week. Standard deviation is represented by error bars. 
medRxiv preprint doi: https://doi.org/10.1101/2022.02.04.22270304; this version posted February $6,2022$. The copyright holder for this preprint (which was not certified by peer review) is the author/funder, who has granted medRxiv a license to display the preprint in
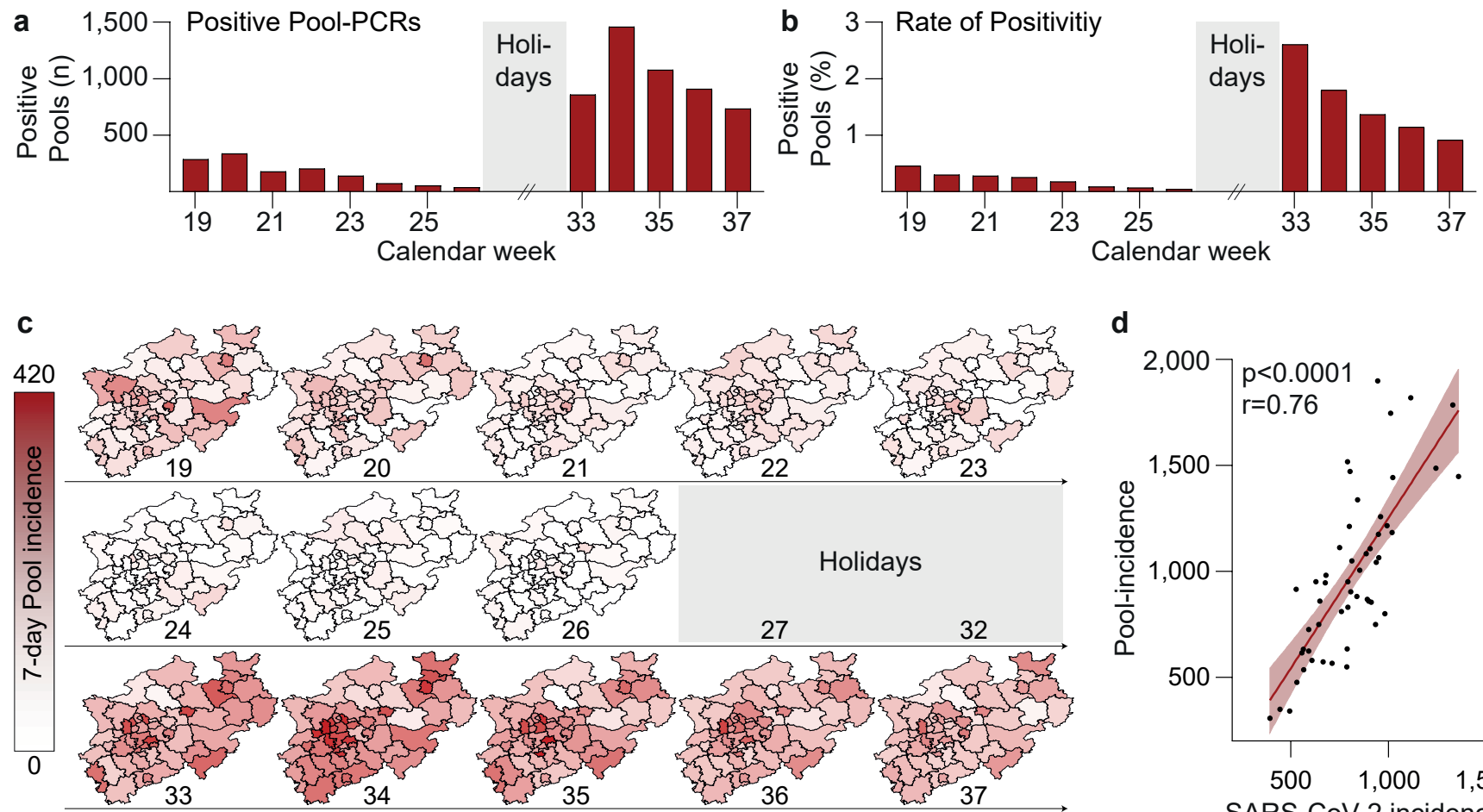

Calendar week in 2021

\section{d}

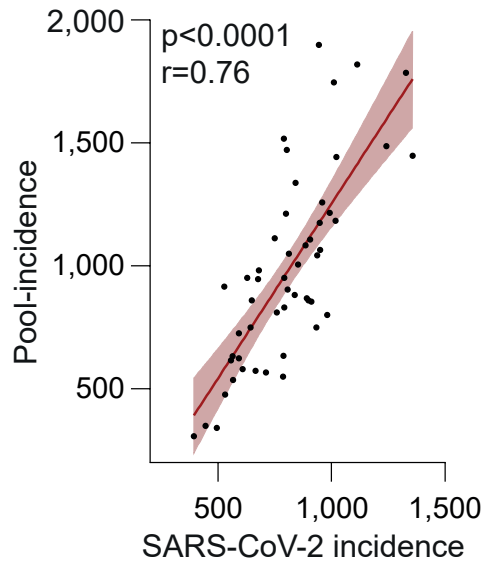

e

$\square$ sc

Schools without

positive Pool-PCR

Schools with

positive Pool-PCRs

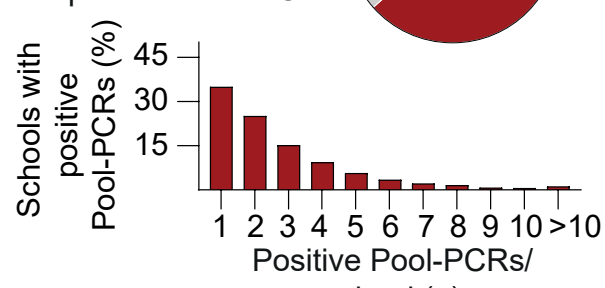

school (n)

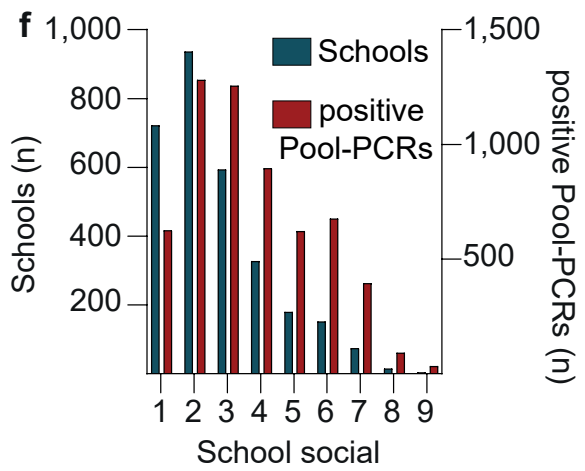

deprivation index (SSDI)

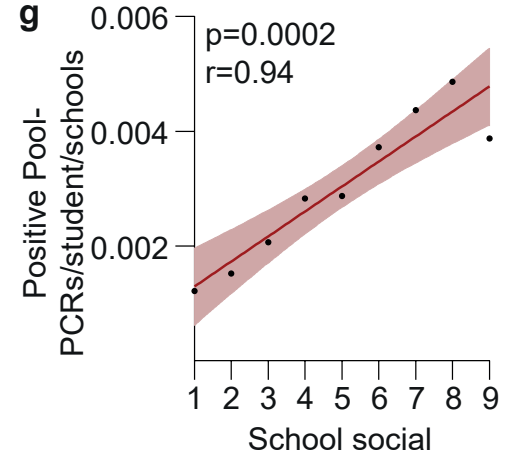

deprivation index (SSDI)

Figure 3: Monitoring SARS-CoV-2 infections in schools

$\mathbf{a}$, The number of positive pool-RT-qPCRs is stratified by calendar week. $\mathbf{b}$, The rate of positivity of pool-RT-qPCRs stratified by calendar week. c, Maps of North Rhine-Westphalia depicting the 7-day pool-incidence per week and district. d, Spearman correlation between pool-incidence and SARS-CoV-2 incidence. Each black dot represents one district of North Rhine-Westphalia. e, Fraction of schools with at least one positive pool-RT-qPCR (pie-chart) and fraction of schools stratified by corresponding number of positive Pool-RT-qPCRs per school (bar chart). f, Number of schools and positive pool-RT-qPCR stratified by school social deprivation index level. g, Spearman correlation between number of positive pool-RT-qPCRs/student/pool and school social deprivation index level. 
medRxiv preprint doi: https://doi.org/10.1101/2022.02.04.22270304; this version posted February 6, 2022. The copyright holder for this preprint (which was not certified by peer review) is the author/funder, who has granted medRxiv a license to display the preprint in

It is made available under a CC-BY-NC-ND 4.0 International license .

a

Estimated distribution of VOCs deteted in positive Pool-PCRs

Calendar week 19-26

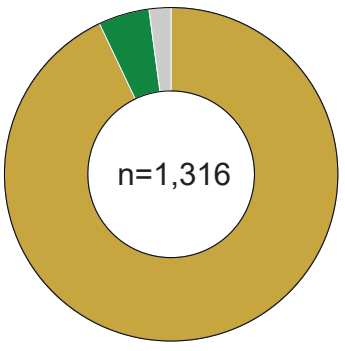

Alpha $(92.95 \%)$

Delta $(4.94 \%)$

Other $(2.13 \%)$
Calendar week 33-37

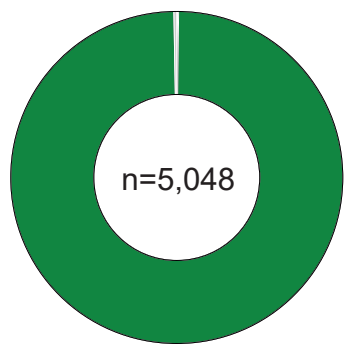

Alpha $(0.18 \%)$

Delta $(99.54 \%)$

Other $(0.28 \%)$ b

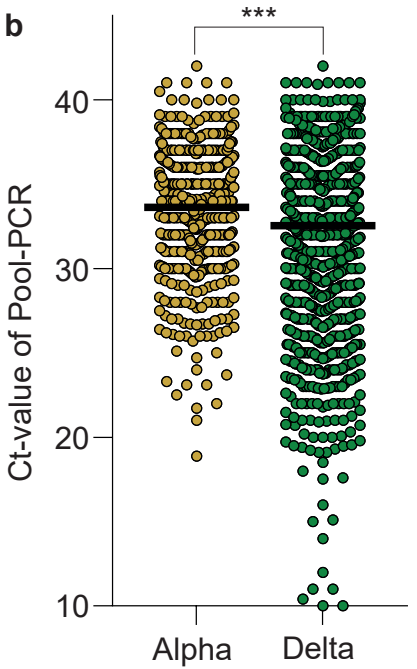

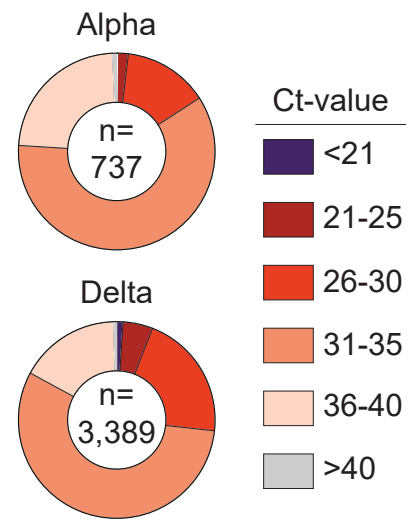

d

\section{Modelling the effect of the delta variant on the number infected children per positive pool-RT-qPCR}

\begin{tabular}{|c|}
\hline \hline Expectation \\
\hline $\begin{array}{c}\text { Prediction of } \mathbf{P} \\
\text { Probability of every } \\
\text { tested child to be } \\
\text { infected }\end{array}$ \\
\hline Linear model \\
\hline \begin{tabular}{c} 
Calculation of E \\
pospectancy value for every \\
to contain $>1$ infected child \\
\hline Binomial distribution
\end{tabular} \\
\hline
\end{tabular}

Observation

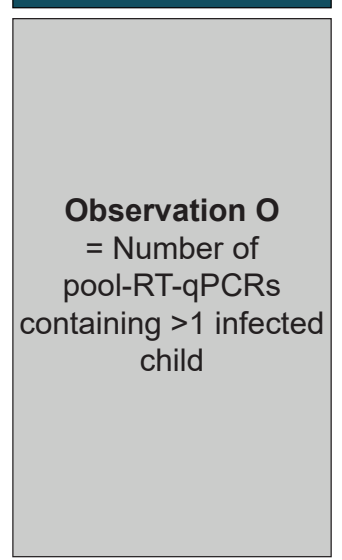

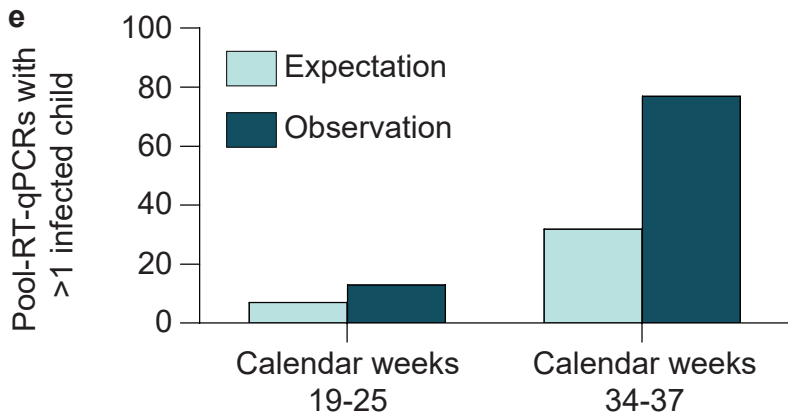

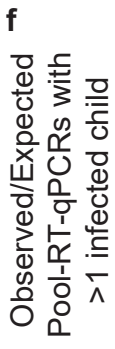

$19-25$

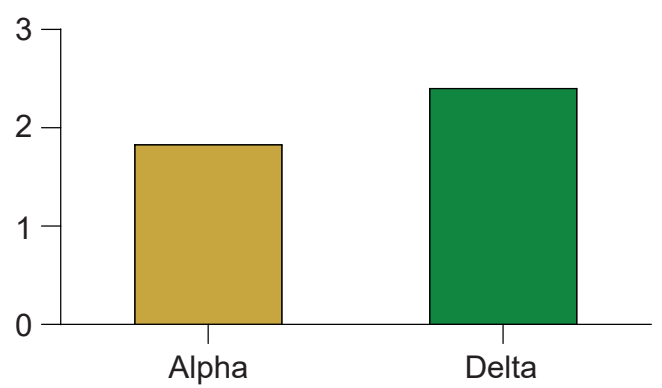

Fig. 4: High-throughput screening reveals differences in infection dynamics for SARS-CoV-2 variants in schools

a, Estimated distribution of VOCs during calendar weeks 19-26 and 33-37. VOCs are indicated by corresponding colors. b, All available Ct-values of positive pool-RT-qPCRs are plotted and stratified by estimated assignment to alpha or delta variant. c, Categorization of Ct-values of positive Pool-RT-qPCRs assigned either alpha or delta variant in corresponding colors. d, Expected and observed numbers of positive pool-RT-qPCRs containing $>1$ infected child were compared by statistical modelling. e, The number of expected and observed positive pool-RT-qPCRs is stratified by time period. $\mathbf{f}$, The ratio of expected and observed numbers of positive pool-RT-qPCRs containing $>1$ infected child is stratified by SARS-CoV-2 variant. 
medRxiv preprint doi: https://doi.org/10.1101/2022.02.04.22270304; this version posted February $6,2022$. The copyright holder for this preprint (which was not certified by peer review) is the author/funder, who has granted medRxiv a license to display the preprint in

It is made available under a CC-BY-NC-ND 4.0 International license .

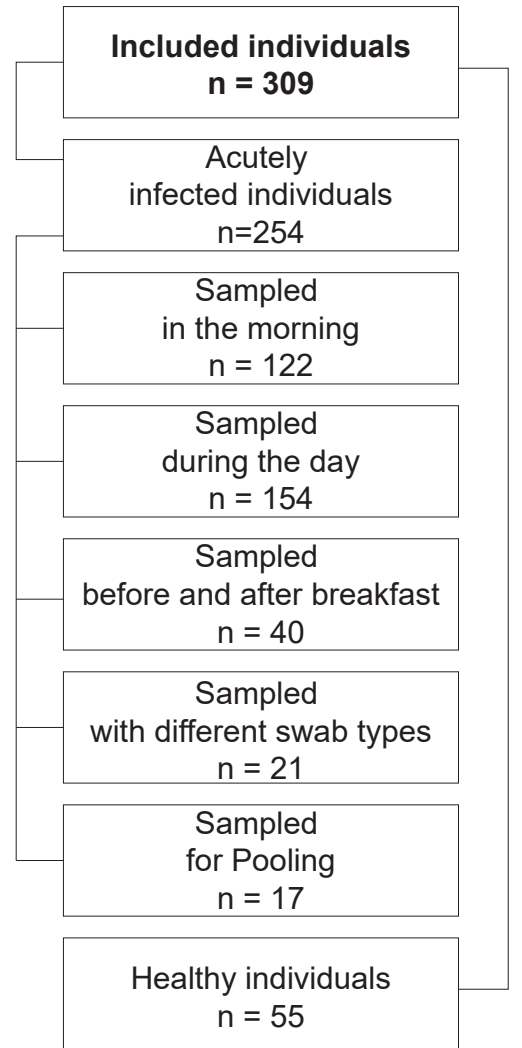

b

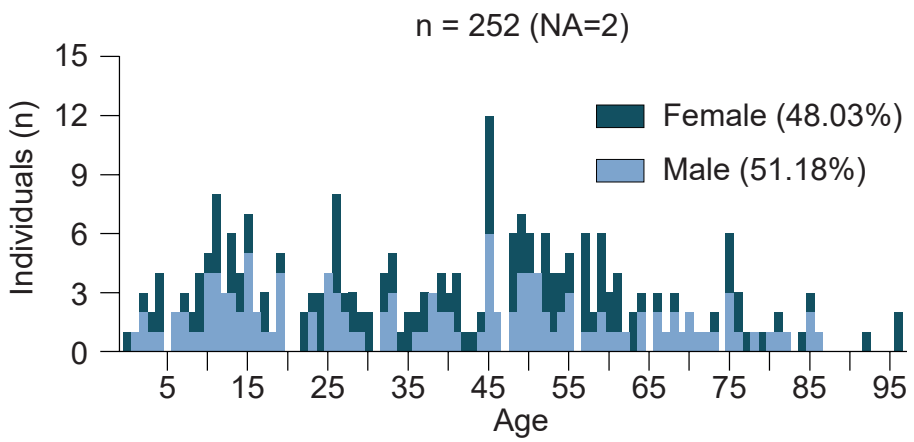

c

Disease severity

d

Days after symptom onset

$n=208$

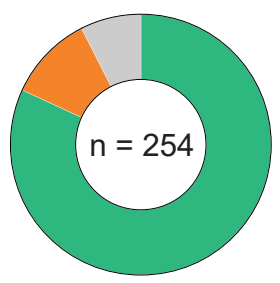

Symptomatic $(81.89 \%)$

Asymptomatic (10.63\%)

NA $(7.48 \%)$

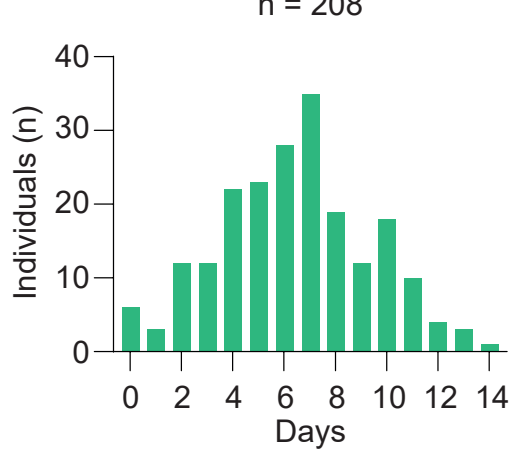

Extended data Fig. 1: Cohort of acutely infected individuals

a, Flowchart including cohort sizes selected for RT-qPCR for the validation of the Lolli-Method. b, Age and gender distribution of the cohort. c, Disease severity among participants. d, Days after symptom onset among participants. 
medRxiv preprint doi: https://doi.org/10.1101/2022.02.04.22270304; this version posted February 6, 2022. The copyright holder for this preprint (which was not certified by peer review) is the author/funder, who has granted medRxiv a license to display the preprint in It is made available under a CC-BY-NC-ND 4.0 International license.

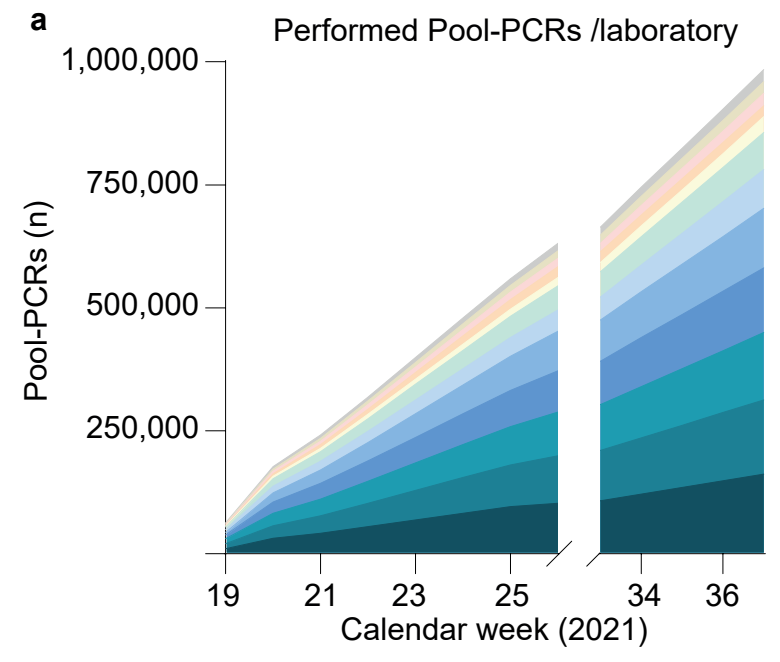

Lab 1
Lab 2 b Testing areas of the laboratories in North Rhine-Westphalia

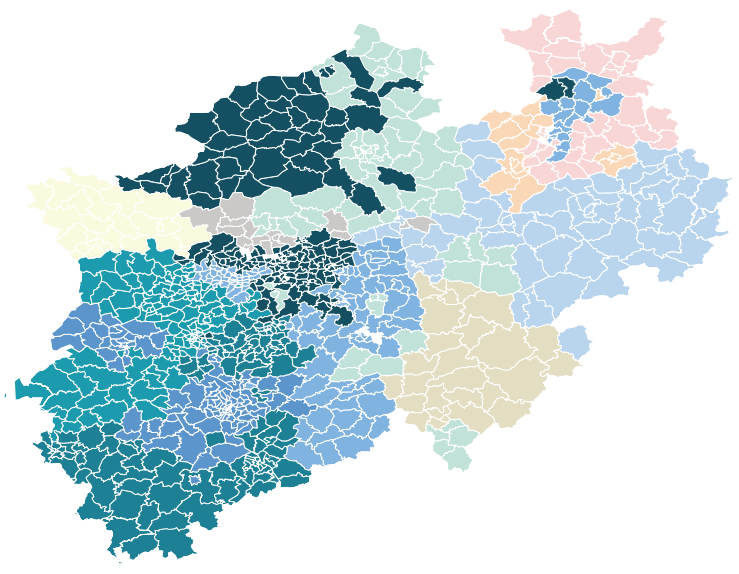

Lab 5

Lab 6

Lab 7

Lab 8

Lab 11

Lab 12

Extended data Fig. 2: Pool-RT-qPCRs and testing areas of 12 laboratories

a, Cumulative number of performed pool-RT-qPCRs for each laboratory stratified by calendar week. $\mathbf{b}$, Testing areas in North Rhine-Westphalia of each laboratory. Each laboratory is assigned one corresponding color. 
medRxiv preprint doi: https://doi.org/10.1101/2022.02.04.22270304; this version posted February 6,2022 . The copyright holder for this preprint (which was not certified by peer review) is the author/funder, who has granted medRxiv a license to display the preprint in

It is made available under a CC-BY-NC-ND 4.0 International license.

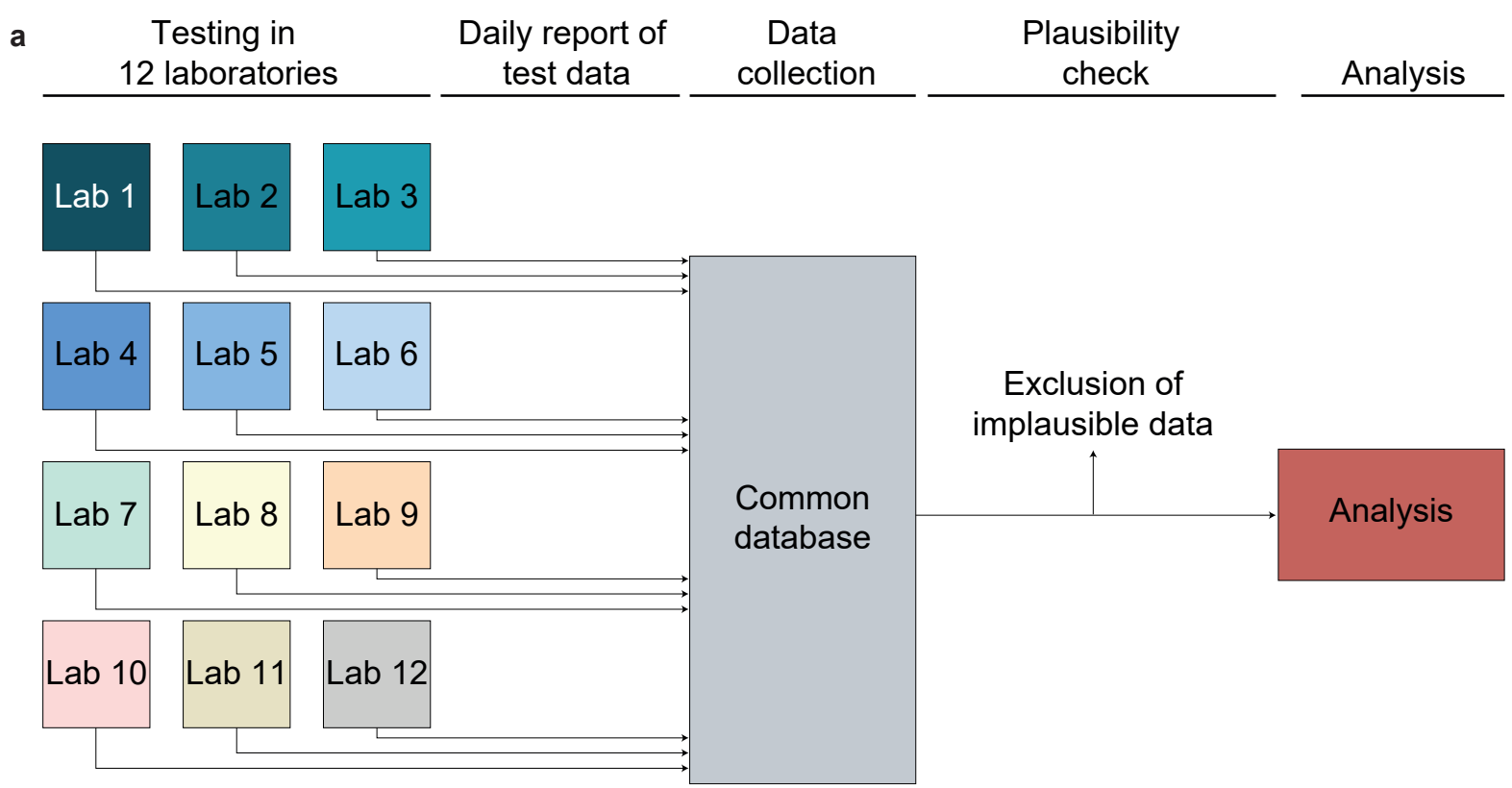

b

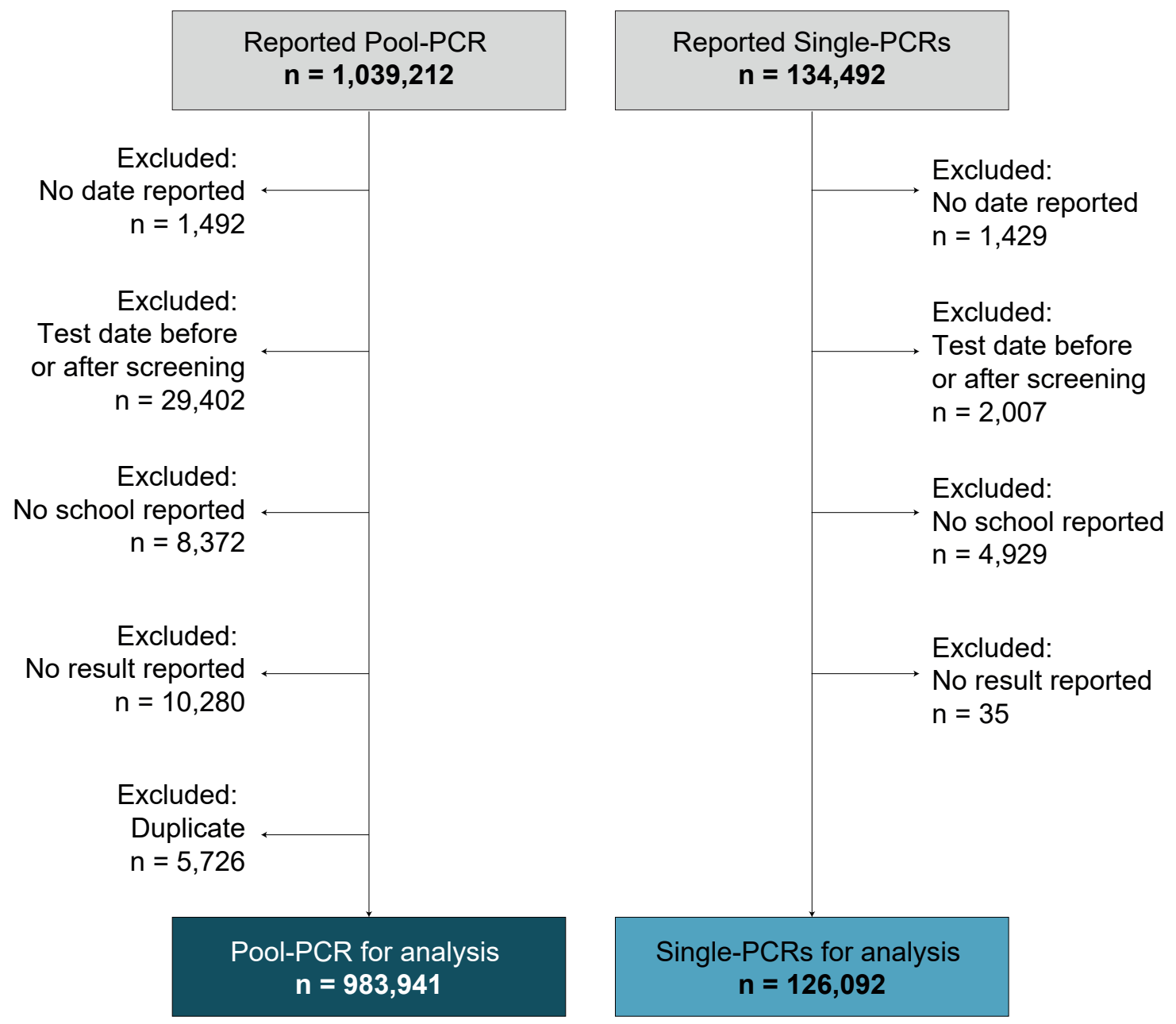

Extended data Fig. 3: Data collection and plausibility checks

a, Flowchart including steps of data collection and quality control. b, Flowchart including details of data plausibility checks for RT-qPCRs indicating the numbers of RT-qPCRs that were used for analysis. 
medRxiv preprint doi: https://doi.org/10.1101/2022.02.04.22270304; this version posted February 6, 2022. The copyright holder for this preprint (which was not certified by peer review) is the author/funder, who has granted medRxiv a license to display the preprint in

It is made available under a CC-BY-NC-ND 4.0 International license .

a Time of sample registration and result communication of Pool-PCRs


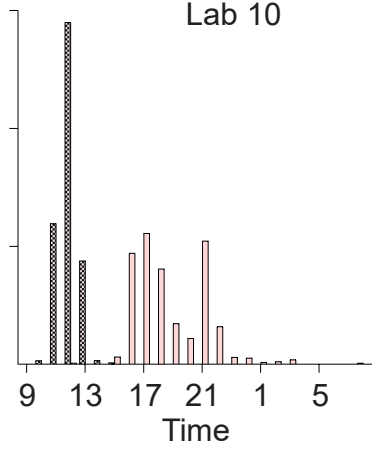

Sample registration

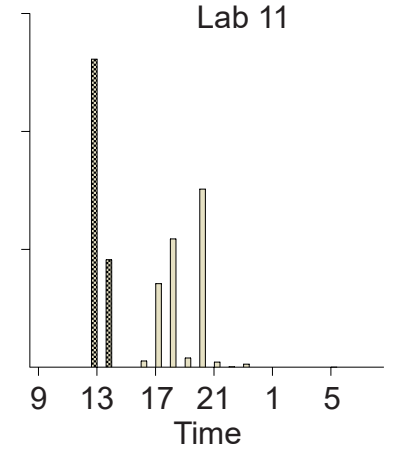

Result communication

b Turn-around time of Pool-PCRs

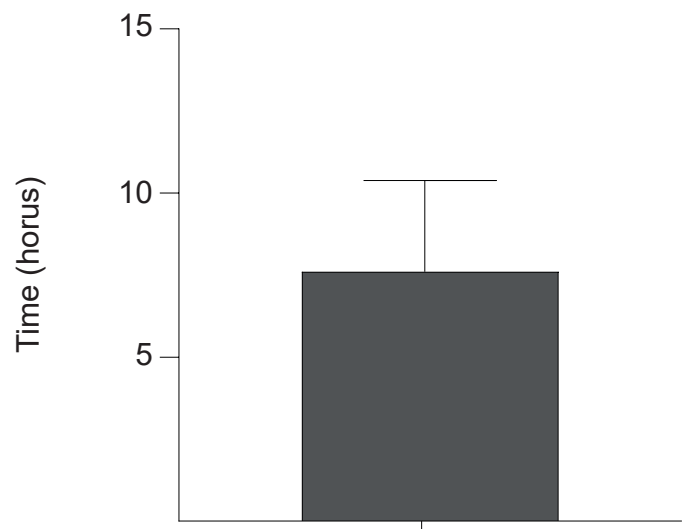

All labs

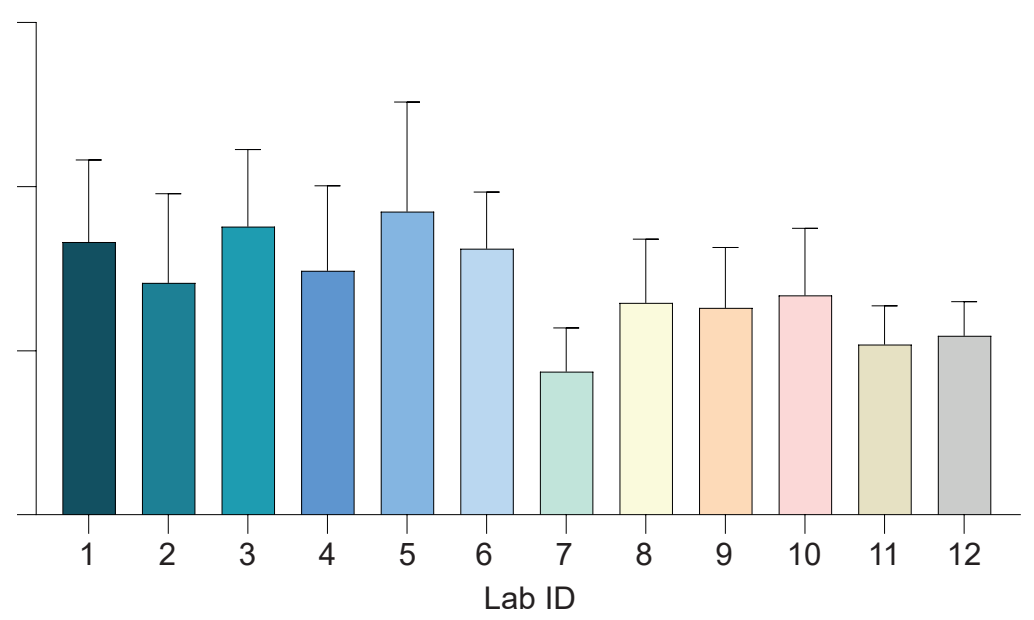


medRxiv preprint doi: https://doi.org/10.1101/2022.02.04.22270304; this version posted February 6, 2022. The copyright holder for this preprint (which was not certified by peer review) is the author/funder, who has granted medRxiv a license to display the preprint in

It is made available under a CC-BY-NC-ND 4.0 International license .

c Time of sample registration and result communication of Single-PCRs
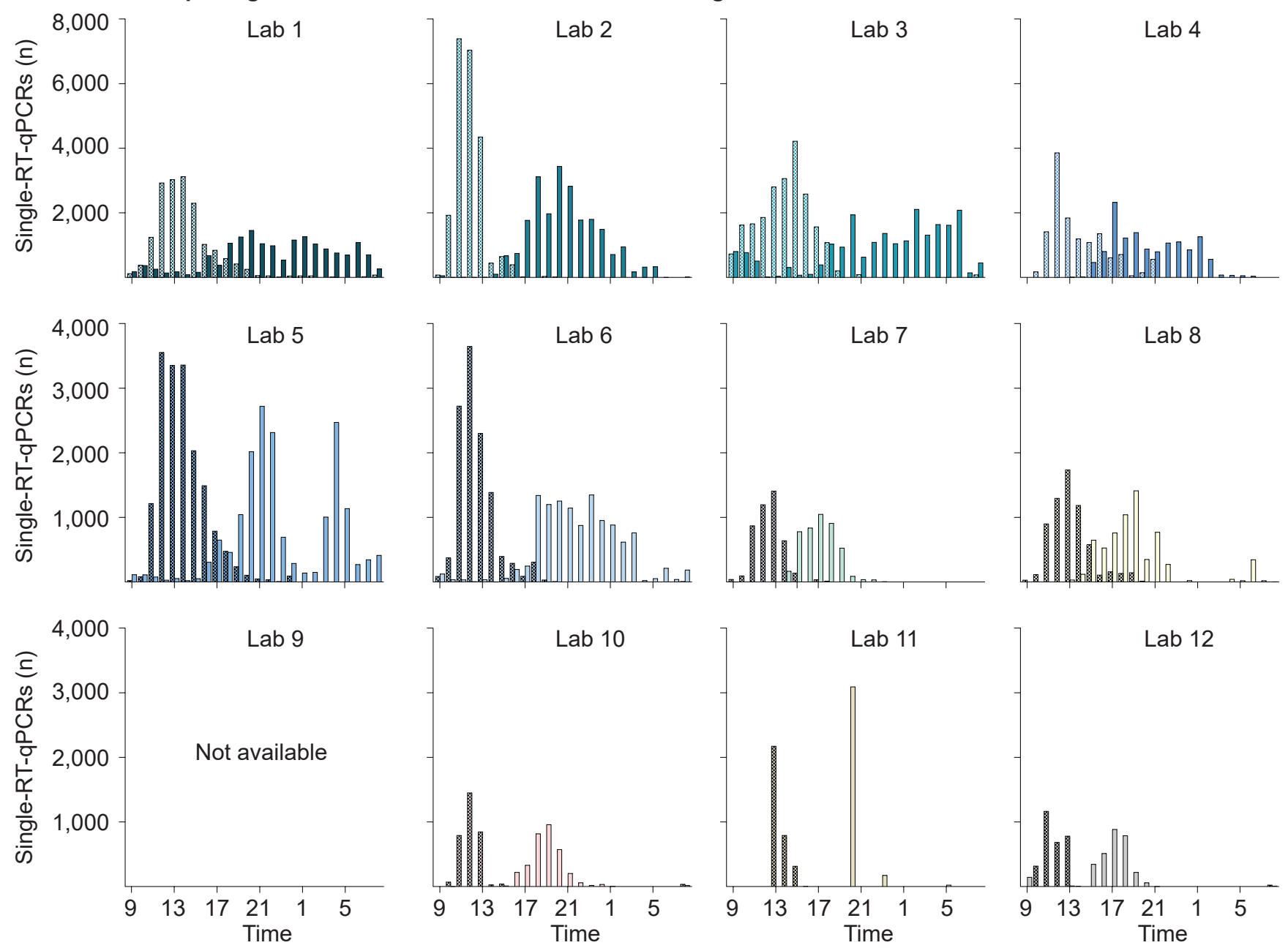

- Sample registration

Result communication

d Turn-around time of Single-PCRs

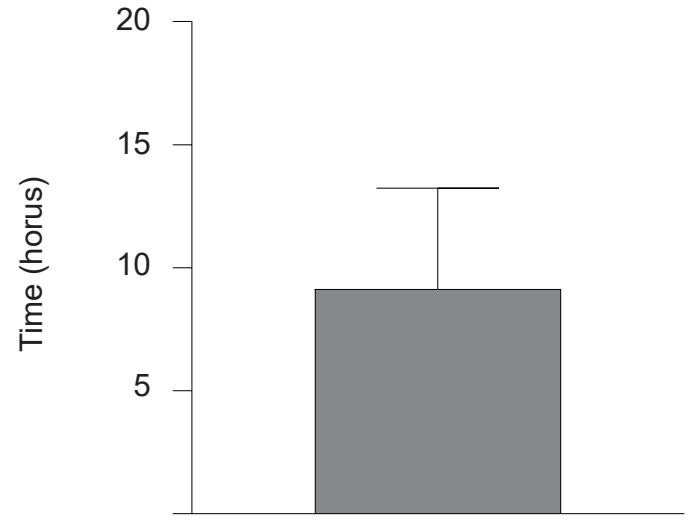

All labs

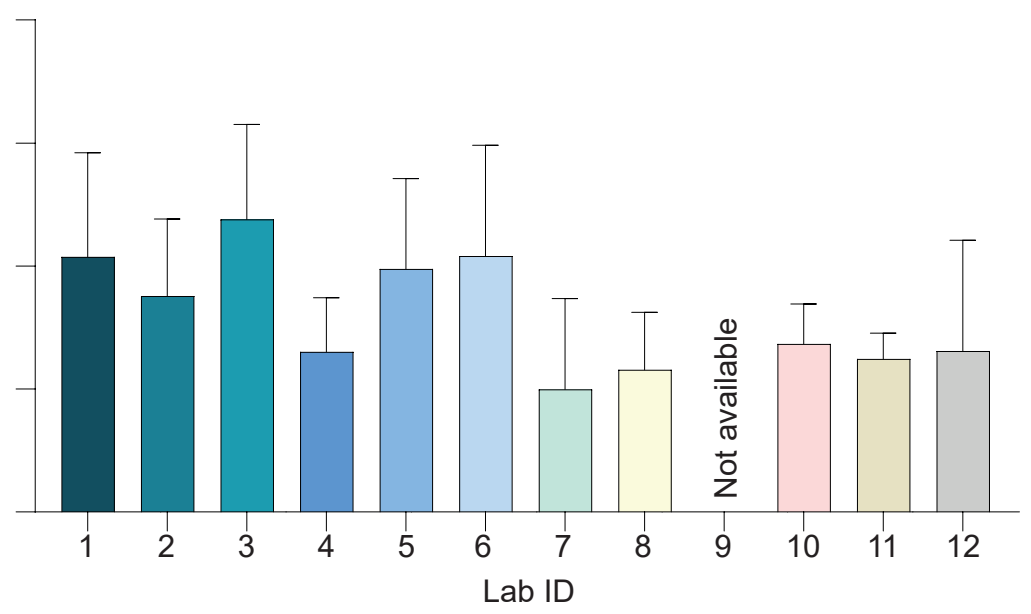

Extended data Fig. 4: Turn-around time of RT-qPCRs

$\mathbf{a}$, The bar charts represent the time of registration and result communication of pool-RT-qPCRs of each laboratory. $\mathbf{b}$, Turn-around time of pool-RT-qPCRs. The error bar represents the standard deviation. $\mathbf{c}$, The bar charts represent the time of registration and result communication of single-RT-qPCRs of each laboratory. $\mathbf{d}$, Turn-around time of single-RT-qPCRs. The error bar represents the standard deviation. 
medRxiv preprint doi: https://doi.org/10.1101/2022.02.04.22270304; this version posted February 6, 2022. The copyright holder for this preprint (which was not certified by peer review) is the author/funder, who has granted medRxiv a license to display the preprint in perpetuity.

It is made available under a CC-BY-NC-ND 4.0 International license

a
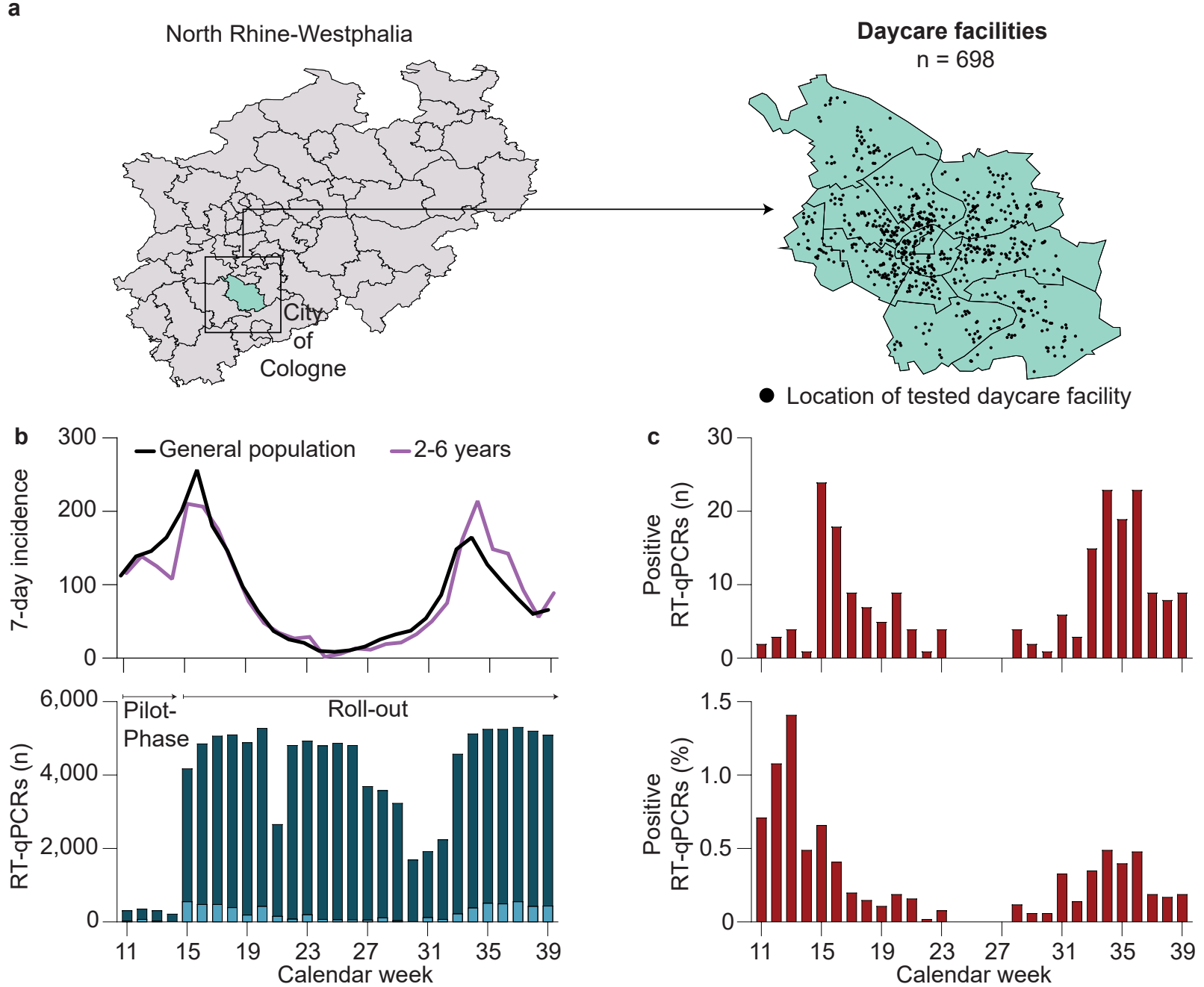

Extended data Fig. 5: Implementation of the Lolli-Method in daycare facilities

a, Map of North Rhine-Westphalia indicating the locations of the tested daycare facilities in the city Cologne. $\mathbf{b}$, SARS-CoV-2 7-day incidence in Cologne (top) and number of performed RT-qPCRs (bottom) stratified by calendar week. c, Number of positive pool-RT-qPCRs and rate of positivity of pool-RT-qPCRs stratified by calendar week. 
medRxiv preprint doi: https://doi.org/10.1101/2022.02.04.22270304; this version posted February $6,2022$. The copyright holder for this preprint (which was not certified by peer review) is the author/funder, who has granted medRxiv a license to display the preprint in perpetuity.

It is made available under a CC-BY-NC-ND 4.0 International license.

a
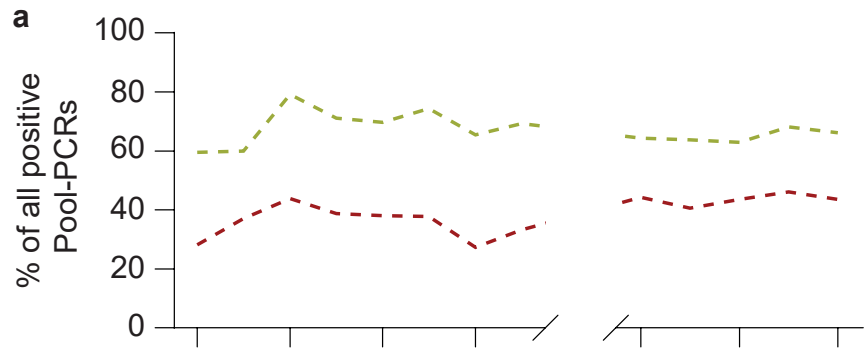

- - - Pools with at least 1 matched Single-PCR

- - Pools with at least 1 matched positive Single-PCR

b

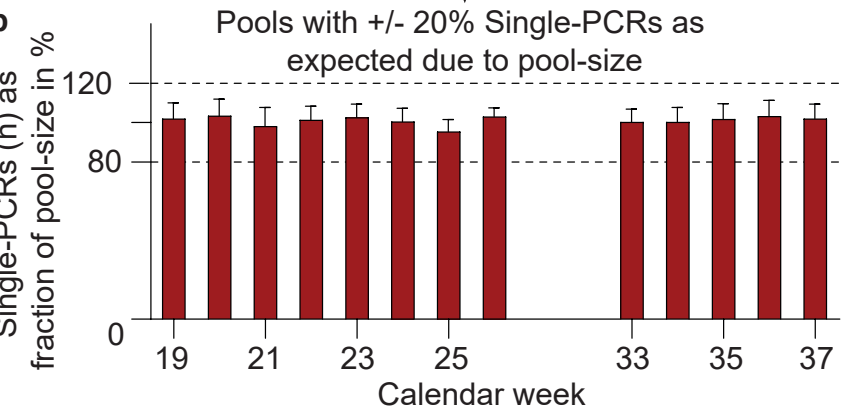

c Positive Single-PCRs/ Pool-PCR:
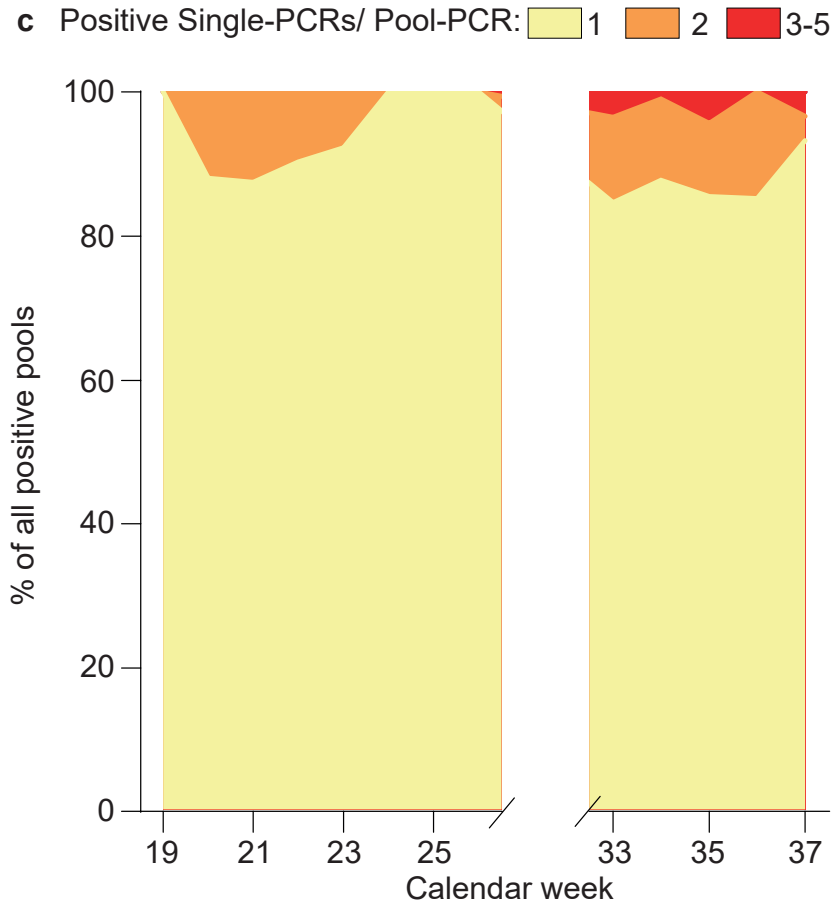

Extended data Fig. 6: Number of infected individuals in positive pool-RT-qPCRs

a, Overview on data quality. b, Only pool-RT-qPCRs with at least one assigned positive single-RT-qPCR were used for further analysis. Out of those, only pool-RT-qPCRs were analyzed when the number of single-RT-qPCR was between 80 and $120 \%$ of the expected number, according to the reported pool-size. c, Categorization of number of positive single-RT-qPCRs/positive pool-RT-qPCR stratified by calendar week. 
medRxiv preprint doi: https://doi.org/10.1101/2022.02.04.22270304; this version posted February 6, 2022. The copyright holder for this preprint (which was not certified by peer review) is the author/funder, who has granted medRxiv a license to display the preprint in

perpetuity.
It is made available under a CC-BY-NC-ND 4.0 International license .

a $\quad$ North Rhine-Westphalia
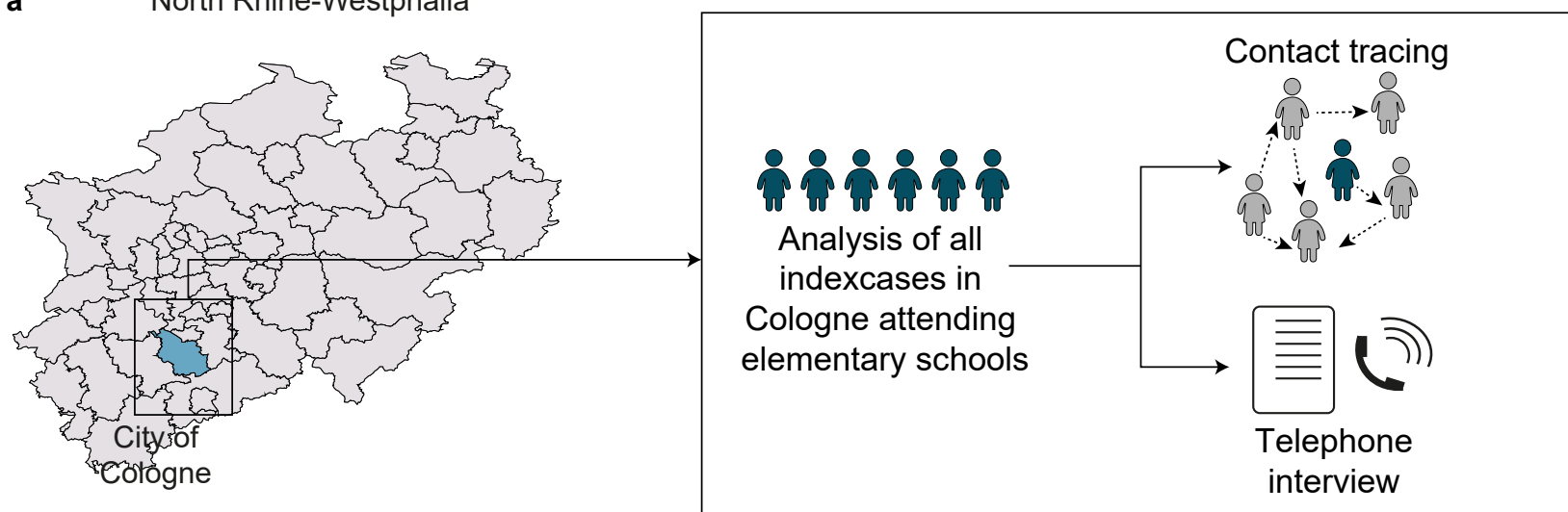

b

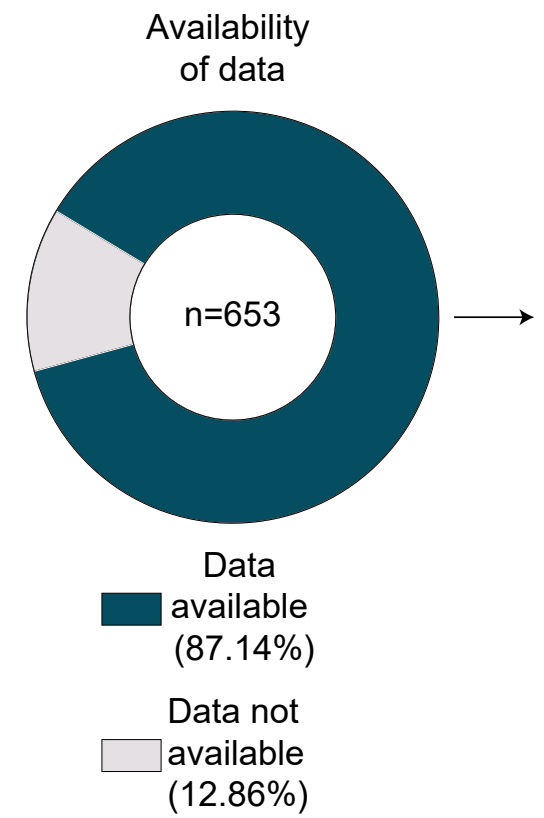

Participation in the test program

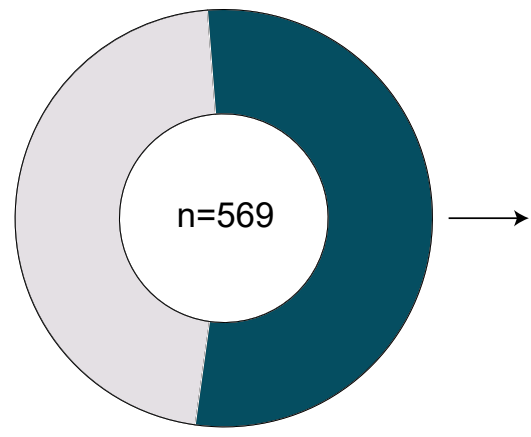

Tested in screening within 3 days before $(53.43 \%)$

Not tested in screening within 3 days before $(46.57 \%)$
Detection

rate

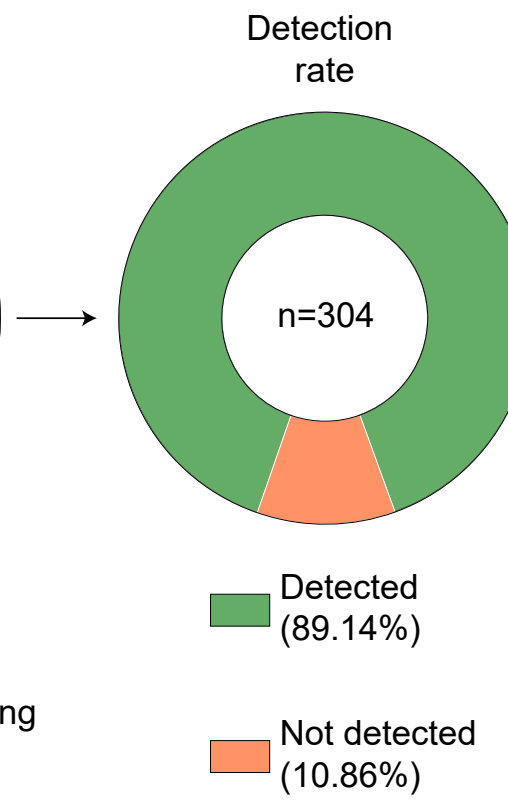

$(10.86 \%)$

Extended data Fig. 7: Determination of the SARS-CoV-2 detection rate of the Lolli-Method

a, Contact-tracing data of all index-cases attending elementary schools in the city of Cologne were analyzed.

b, Pie-chart categorizing all index-cases attending elementary schools in Cologne. 
medRxiv preprint doi: https://doi.org/10.1101/2022.02.04.22270304; this version posted February $6,2022$. The copyright holder for this preprint (which was not certified by peer review) is the author/funder, who has granted medRxiv a license to display the preprint in

It is made available under a CC-BY-NC-ND 4.0 International license .
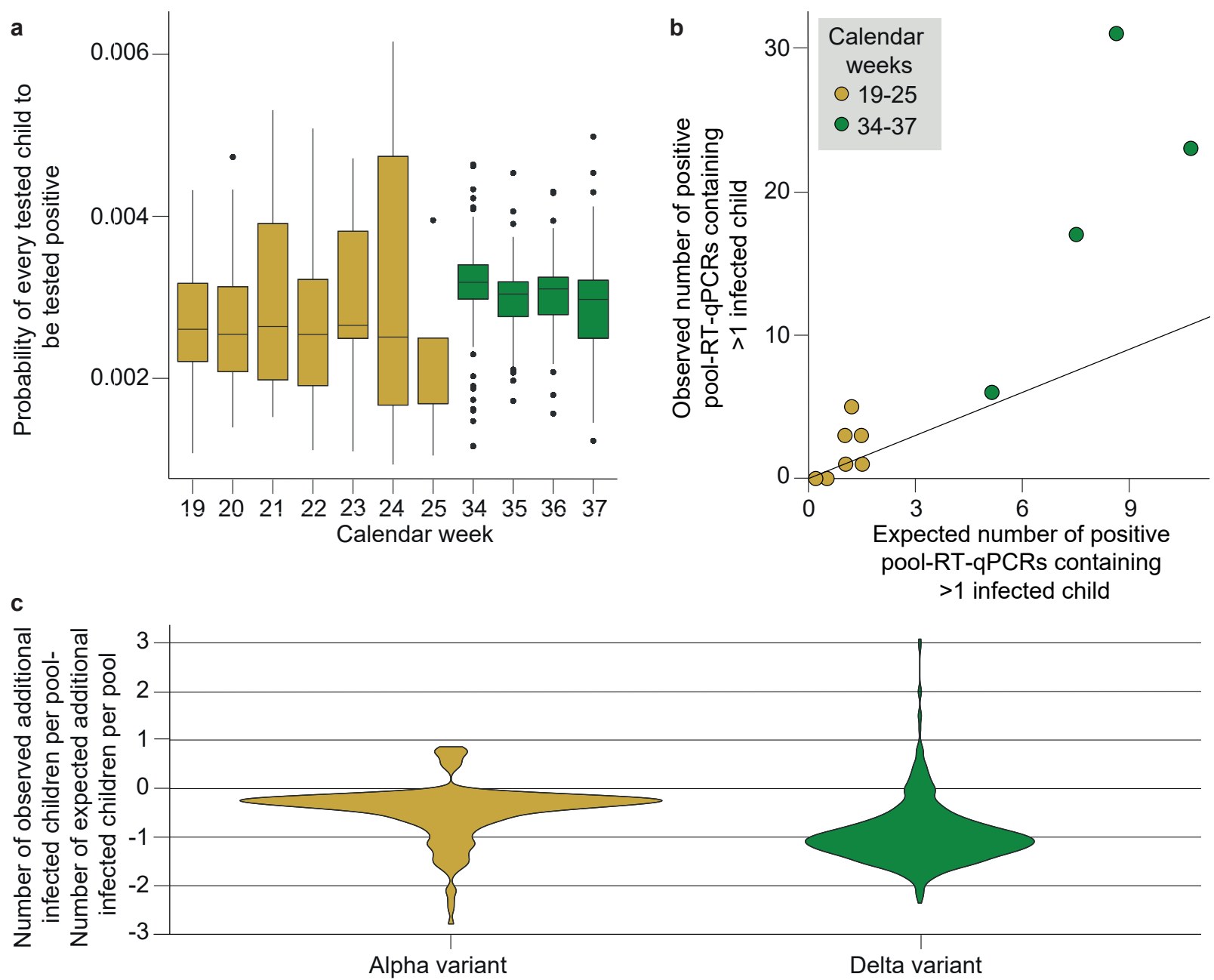

Extended data Fig. 8: Modelling differences in infections dynamics of SARS-CoV-2 variants with the Lolli-Method in schools

a, Boxplot indicating the probability of every child to be tested positive stratified by calendar week. Calendar weeks 19-25 (yellow boxes) und 34-37 (green boxes) are included in this plot. b, Observed number stratified by expected number of positive pool-RT-qPCRs containing $>1$ infected child per calendar week. Calendar weeks 19-25 (yellow dots) and 34-37 (green dots) are included in this plot. c, Violin plot indicating the difference between observed and expected number of additional infected children per positive pool-RT-qPCR stratified by SARS-CoV-2 variant $(p=0.035, W S R)$. 
medRxiv preprint doi: https://doi.org/10.1101/2022.02.04.22270304; this version posted February 6, 2022. The copyright holder for this preprint (which was not certified by peer review) is the author/funder, who has granted medRxiv a license to display the preprint in

It is made available under a CC-BY-NC-ND 4.0 International license.

a

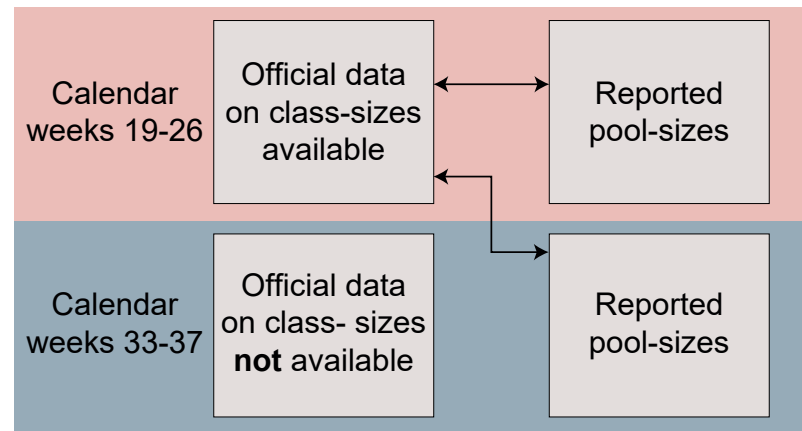

b

School lesson

\begin{tabular}{|l|c|c|c|c|}
\hline \multirow{2}{*}{$\begin{array}{l}\text { Split-class } \\
\text { lessons }\end{array}$} & No test & Test & No test & Test \\
\cline { 2 - 5 } & Test & No test & Test & No test \\
\hline \hline $\begin{array}{l}\text { Full-class } \\
\text { lessons }\end{array}$ & Test & No test & Test & No test \\
\cline { 2 - 5 } & & & \\
\hline
\end{tabular}

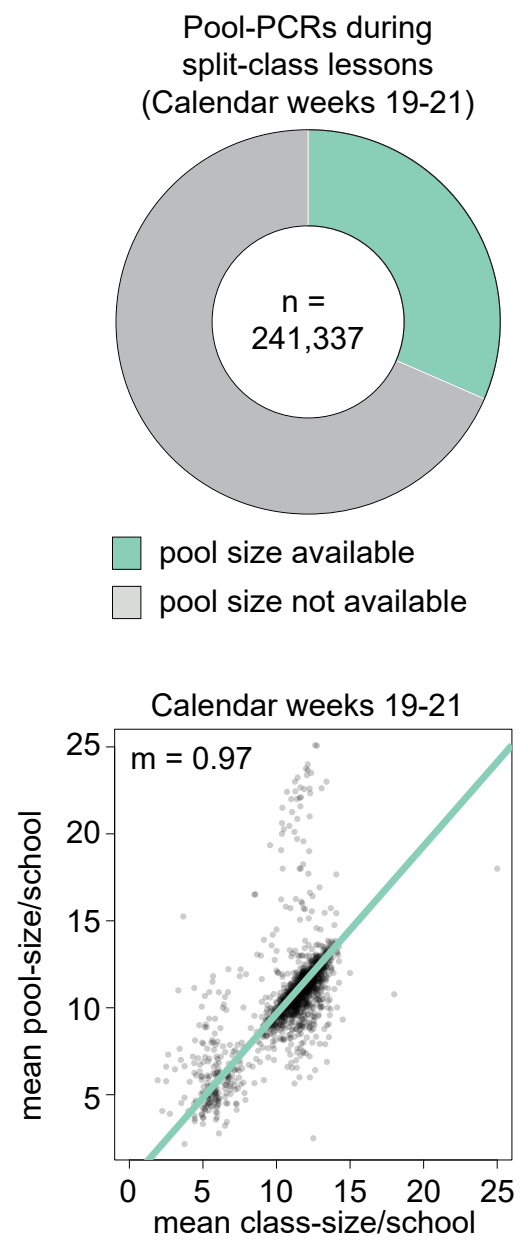

Pool-PCRs during

full-class lessons

(Calendar weeks 22-26)

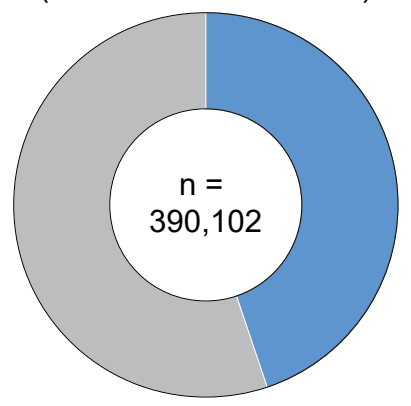

pool size available

pool size not available
Pool-PCRs during

full-class lessons

(Calendar weeks 33-37)

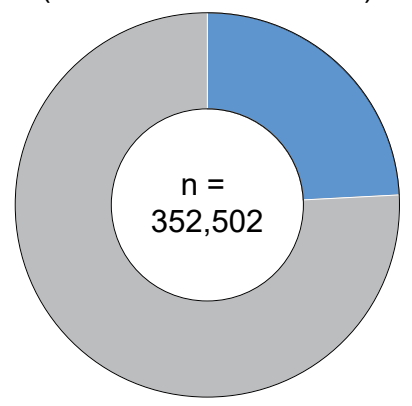

pool size available

pool size not available d
Calendar weeks 22-26

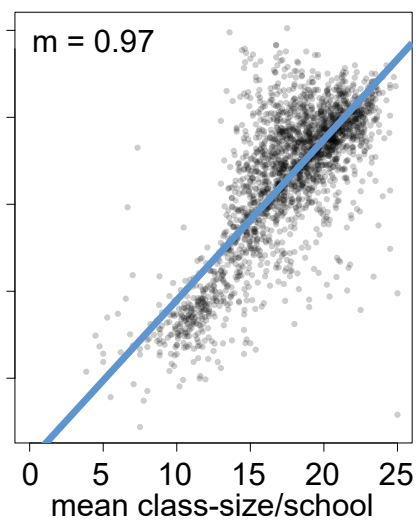

Calendar weeks 33-37

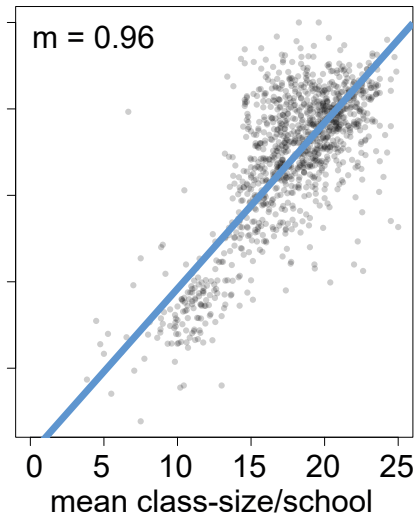

\section{Extended data Fig. 9: Estimating the number of tested individuals in schools}

a, Experimental design and availability of data on class sizes. b, Illustration of two different lesson-models applied during the screening. c, Data availability on pool-sizes. d, Means of class sizes per school and means of reported pool-sizes per school were mapped as part of a linear model with a forced Y-axis intercept of 0. 
medRxiv preprint doi: https://doi.org/10.1101/2022.02.04.22270304; this version posted February 6 , 2022. The copyright holder for this

preprint (which was not certified by peer review) is the author/funder, who has granted medRxiv a license to display the preprint in

It is made available under a CC-BY-NC-ND 4.0 International license .

\section{Extended data Table 1a}

\begin{tabular}{|c|c|c|c|c|c|c|c|c|c|c|c|c|c|c|c|}
\hline \multicolumn{4}{|c|}{ General information } & \multicolumn{2}{|c|}{ Sampling information } & \multicolumn{5}{|c|}{ Lolli-swab } & & & $\mathrm{O}-/ \mathrm{O}$ & swab & \\
\hline ID & Gender & $\begin{array}{c}\begin{array}{c}\text { Days } \\
\text { after }\end{array} \\
\text { symptom } \\
\text { onset }\end{array}$ & $\begin{array}{c}\text { Days } \\
\text { after } \\
\text { first } \\
\text { positive } \\
\text { PCR }\end{array}$ & $\begin{array}{c}\text { Side } \\
\text { of } \\
\text { sampling }\end{array}$ & $\begin{array}{l}\text { Sampling } \\
\text { time }\end{array}$ & Orf & E & $\mathbf{N}$ & $\begin{array}{c}\text { RdRp/ } \\
\text { N genes }\end{array}$ & Viral load & Orf & E & $\mathbf{N}$ & $\begin{array}{l}\text { RdRp/ } \\
\text { N genes }\end{array}$ & $\begin{array}{l}\text { Viral } \\
\text { load }\end{array}$ \\
\hline 3 & M & 5 & - & Cologne & During day & - & - & - & NEG & $0,00 \mathrm{E}+00$ & - & - & - & 35,25 & $1,03 E+02$ \\
\hline 4 & $\mathrm{~F}$ & 2 & - & Cologne & During day & - & - & - & 41,68 & $1,37 \mathrm{E}+00$ & - & - & - & NEG & $0,00 \mathrm{E}+00$ \\
\hline 6 & $\mathrm{~F}$ & - & 4 & Cologne & During day & - & - & - & NEG & $0,00 \mathrm{E}+00$ & - & - & - & 19,64 & $3,71 \mathrm{E}+06$ \\
\hline 7 & M & - & - & Cologne & During day & - & - & - & 40,76 & $2,54 \mathrm{E}+00$ & - & - & - & 23,66 & $2,49 E+05$ \\
\hline 8 & M & - & - & Cologne & During day & - & - & - & 31,2 & $1,57 \mathrm{E}+03$ & - & - & - & 26,56 & $3,54 \mathrm{E}+04$ \\
\hline 9 & M & - & - & Cologne & During day & - & - & - & 37,69 & $2,00 \mathrm{E}+01$ & - & - & - & 28,48 & $9,76 \mathrm{E}+03$ \\
\hline 10 & M & - & - & Cologne & During day & - & - & - & 24,37 & $1,54 \mathrm{E}+05$ & - & - & - & 13,5 & $2,30 \mathrm{E}+08$ \\
\hline 11 & M & - & - & Cologne & During day & - & - & - & NEG & $0,00 \mathrm{E}+00$ & - & - & - & 15,4 & $6,41 \mathrm{E}+07$ \\
\hline 12 & $\mathrm{~F}$ & 9 & - & Cologne & During day & - & - & - & NEG & $0,00 \mathrm{E}+00$ & - & - & - & 37,16 & $2,86 \mathrm{E}+01$ \\
\hline 13 & $\mathrm{~F}$ & 8 & - & Cologne & During day & - & - & - & NEG & $0,00 \mathrm{E}+00$ & - & - & - & 33,4 & $3,58 \mathrm{E}+02$ \\
\hline 15 & M & 10 & - & Cologne & During day & - & - & - & NEG & $0,00 \mathrm{E}+00$ & - & - & - & 39,7 & $5,18 \mathrm{E}+00$ \\
\hline 16 & $M$ & 2 & - & Cologne & During day & - & - & - & 33,58 & $3,17 \mathrm{E}+02$ & - & - & - & 21,61 & $9,87 \mathrm{E}+05$ \\
\hline 17 & M & - & 8 & Cologne & During day & - & - & - & NEG & $0,00 \mathrm{E}+00$ & - & - & - & 34,73 & $1,46 \mathrm{E}+02$ \\
\hline 18 & $\mathrm{~F}$ & 5 & - & Cologne & During day & - & - & - & NEG & $0,00 \mathrm{E}+00$ & - & - & - & 26,38 & $4,00 E+04$ \\
\hline 19 & $\mathrm{~F}$ & - & 6 & Cologne & During day & - & - & - & 33,53 & $3,28 \mathrm{E}+02$ & - & - & - & 29,8 & $4,02 E+03$ \\
\hline 20 & $\mathrm{~F}$ & 6 & - & Cologne & During day & - & - & - & 37,64 & $2,07 \mathrm{E}+01$ & - & - & - & 24,73 & $1,21 \mathrm{E}+05$ \\
\hline 21 & $\mathrm{~F}$ & 9 & - & Cologne & During day & - & - & - & 32,46 & $6,73 \mathrm{E}+02$ & - & - & - & 24,35 & $1,57 \mathrm{E}+05$ \\
\hline 22 & M & - & 8 & Cologne & During day & - & - & - & NEG & $0,00 \mathrm{E}+00$ & - & - & - & 36,06 & $5,99 \mathrm{E}+01$ \\
\hline 23 & $M$ & 8 & - & Cologne & During day & - & - & - & NEG & $0,00 \mathrm{E}+00$ & - & - & - & 39,12 & $7,66 \mathrm{E}+00$ \\
\hline 24 & M & 10 & - & Cologne & During day & - & - & - & 36,74 & $3,79 \mathrm{E}+01$ & - & - & - & 34,56 & $1,64 \mathrm{E}+02$ \\
\hline 25 & $\mathrm{~F}$ & 6 & - & Cologne & Morning & - & - & - & 31,76 & $1,08 \mathrm{E}+03$ & - & - & - & 23,75 & $2,34 \mathrm{E}+05$ \\
\hline 26 & $\mathrm{~F}$ & 11 & - & Cologne & Morning & - & - & - & 31,42 & $1,35 \mathrm{E}+03$ & - & - & - & 23,28 & $3,21 E+05$ \\
\hline 27 & $\mathrm{~F}$ & 5 & - & Cologne & Morning & - & - & - & 32,4 & $7,00 \mathrm{E}+02$ & - & - & - & 22,19 & $6,68 \mathrm{E}+05$ \\
\hline 28 & $\mathrm{~F}$ & 6 & - & Cologne & Morning & - & - & - & 33,73 & $2,86 \mathrm{E}+02$ & - & - & - & 24,99 & $1,02 E+05$ \\
\hline 29 & $\mathrm{~F}$ & - & 7 & Cologne & Morning & - & - & - & 27,99 & $1,36 \mathrm{E}+04$ & - & - & - & 25,01 & $1,00 \mathrm{E}+05$ \\
\hline 31 & $\mathrm{~F}$ & 10 & - & Cologne & Morning & - & - & - & 33,88 & $2,59 E+02$ & - & - & - & 16,68 & $2,71 E+07$ \\
\hline 32 & $M$ & 8 & - & Cologne & Morning & - & - & - & NEG & $0,00 \mathrm{E}+00$ & - & - & - & 27,9 & $1,44 \mathrm{E}+04$ \\
\hline 33 & $\mathrm{~F}$ & 7 & - & Cologne & Morning & - & - & - & 31,94 & $9,54 \mathrm{E}+02$ & - & - & - & 22,48 & $5,50 \mathrm{E}+05$ \\
\hline 34 & $\mathrm{~F}$ & 5 & - & Cologne & Morning & - & - & - & 35,8 & $7,13 \mathrm{E}+01$ & - & - & - & 26,05 & $4,99 \mathrm{E}+04$ \\
\hline 35 & $M$ & 4 & - & Cologne & Morning & - & - & - & NEG & $0,00 \mathrm{E}+00$ & - & - & - & 38,19 & $1,43 E+01$ \\
\hline 36 & $\mathrm{~F}$ & 4 & - & Cologne & Morning & - & - & - & 38,82 & $9,37 \mathrm{E}+00$ & - & - & - & 26,27 & $4,31 E+04$ \\
\hline 37 & M & 10 & - & Cologne & Morning & - & - & - & 32,56 & $6,29 E+02$ & - & - & - & 25,16 & $9,08 \mathrm{E}+04$ \\
\hline 39 & M & 10 & - & Cologne & Morning & - & - & - & NEG & $0,00 \mathrm{E}+00$ & - & - & - & 32,68 & $5,80 \mathrm{E}+02$ \\
\hline 40 & $M$ & 7 & - & Cologne & Morning & - & - & - & 37,71 & $1,97 \mathrm{E}+01$ & - & - & - & 34,14 & $2,17 \mathrm{E}+02$ \\
\hline 42 & $M$ & 6 & - & Cologne & Morning & - & - & - & 30,02 & $3,47 \mathrm{E}+03$ & - & - & - & 17,99 & $1,12 \mathrm{E}+07$ \\
\hline 43 & $\mathrm{~F}$ & 7 & - & Cologne & Morning & - & - & - & 33,23 & $4,01 \mathrm{E}+02$ & - & - & - & 21,66 & $9,54 \mathrm{E}+05$ \\
\hline 45 & $\mathrm{~F}$ & 11 & - & Cologne & Morning & - & - & - & 33,04 & $4,55 \mathrm{E}+02$ & - & - & - & 28,95 & $7,11 \mathrm{E}+03$ \\
\hline 46 & M & 5 & - & Cologne & Morning & - & - & - & 24,74 & $1,20 \mathrm{E}+05$ & - & - & - & 29,22 & $5,93 E+03$ \\
\hline 47 & $\mathrm{~F}$ & 10 & - & Cologne & Morning & - & - & - & NEG & $0,00 \mathrm{E}+00$ & - & - & - & 33,36 & $3,67 \mathrm{E}+02$ \\
\hline 48 & $\mathrm{~F}$ & 12 & - & Cologne & Morning & - & - & - & 35,15 & $1,10 \mathrm{E}+02$ & - & - & - & 33,97 & $2,44 \mathrm{E}+02$ \\
\hline 49 & M & - & - & Cologne & Morning & - & - & - & 36,64 & $4,05 \mathrm{E}+01$ & - & - & - & NEG & $0,00 \mathrm{E}+00$ \\
\hline 51 & $\mathrm{~F}$ & 11 & - & Cologne & Morning & - & - & - & 41,74 & $1,32 \mathrm{E}+00$ & - & - & - & 34,81 & $1,39 \mathrm{E}+02$ \\
\hline 52 & M & 9 & - & Cologne & Morning & - & - & - & 25,53 & $7,08 \mathrm{E}+04$ & - & - & - & 26,71 & $3,20 E+04$ \\
\hline 53 & M & 9 & - & Cologne & Morning & - & - & - & 27,44 & $1,96 \mathrm{E}+04$ & - & - & - & 31,79 & $1,05 E+03$ \\
\hline 54 & $M$ & 11 & - & Cologne & Morning & - & - & - & NEG & $0,00 \mathrm{E}+00$ & - & - & - & 41,6 & $1,45 E+00$ \\
\hline 55 & $\mathrm{~F}$ & 8 & - & Cologne & Morning & - & - & - & 37,01 & $3,16 \mathrm{E}+01$ & - & - & - & 32,34 & $7,29 \mathrm{E}+02$ \\
\hline 56 & $\mathrm{~F}$ & 8 & - & Cologne & Morning & - & - & - & 32,93 & $4,90 \mathrm{E}+02$ & - & - & - & 29,79 & $4,05 E+03$ \\
\hline 57 & M & - & 4 & Cologne & Morning & - & - & - & 28,09 & $1,27 \mathrm{E}+04$ & - & - & - & 28,88 & $7,46 \mathrm{E}+03$ \\
\hline 62 & M & 10 & - & Cologne & Morning & - & - & - & NEG & $0,00 \mathrm{E}+00$ & - & - & - & 39,24 & $7,06 \mathrm{E}+00$ \\
\hline 65 & M & 13 & - & Cologne & Morning & - & - & - & NEG & $0,00 \mathrm{E}+00$ & - & - & - & 41,68 & $1,37 \mathrm{E}+00$ \\
\hline 66 & $\mathrm{~F}$ & 10 & - & Cologne & Morning & - & - & - & NEG & $0,00 \mathrm{E}+00$ & - & - & - & 35,57 & $8,32 E+01$ \\
\hline 68 & M & - & 7 & Cologne & Morning & - & - & - & NEG & $0,00 \mathrm{E}+00$ & - & - & - & 33,14 & $4,26 \mathrm{E}+02$ \\
\hline 69 & $M$ & - & 3 & Cologne & Morning & - & - & - & 40,99 & $2,18 \mathrm{E}+00$ & - & - & - & 36,05 & $6,03 E+01$ \\
\hline 70 & $M$ & - & 3 & Cologne & Morning & - & - & - & NEG & $0,00 \mathrm{E}+00$ & - & - & - & 40,12 & $3,91 \mathrm{E}+00$ \\
\hline 71 & $\mathrm{~F}$ & 3 & - & Cologne & Morning & - & - & - & NEG & $0,00 \mathrm{E}+00$ & - & - & - & 24,79 & $1,16 \mathrm{E}+05$ \\
\hline 72 & M & 13 & - & Cologne & Morning & - & - & - & 32,32 & $7,39 \mathrm{E}+02$ & - & - & - & 32,47 & $6,68 \mathrm{E}+02$ \\
\hline 72 & M & 13 & - & Cologne & During day & - & - & - & 35,99 & $6,27 \mathrm{E}+01$ & - & - & - & 28,93 & $7,21 E+03$ \\
\hline 74 & $\mathrm{~F}$ & - & - & Cologne & Morning & - & - & - & NEG & $0,00 \mathrm{E}+00$ & - & - & - & 33,56 & $3,21 E+02$ \\
\hline 75 & $\mathrm{~F}$ & 3 & - & Cologne & Morning & - & - & - & 29,11 & $6,39 \mathrm{E}+03$ & - & - & - & 22,93 & $4,06 \mathrm{E}+05$ \\
\hline 75 & $\mathrm{~F}$ & 3 & - & Cologne & During day & - & - & - & 30,24 & $2,99 \mathrm{E}+03$ & - & - & - & 23,67 & $2,47 \mathrm{E}+05$ \\
\hline 77 & $M$ & 8 & 4 & Cologne & Morning & - & - & - & 33,18 & $4,15 \mathrm{E}+02$ & - & - & - & 24,21 & $1,72 \mathrm{E}+05$ \\
\hline 77 & M & 8 & 4 & Cologne & During day & - & - & - & NEG & $0,00 \mathrm{E}+00$ & - & - & - & 27,9 & $1,44 \mathrm{E}+04$ \\
\hline 82 & $\mathrm{~F}$ & 5 & - & Cologne & Morning & - & - & - & 25,47 & $7,37 \mathrm{E}+04$ & - & - & - & 21,9 & $8,12 \mathrm{E}+05$ \\
\hline 82 & $\mathrm{~F}$ & 5 & - & Cologne & During day & - & - & - & 28,3 & $1,10 \mathrm{E}+04$ & - & - & - & 19,09 & $5,37 \mathrm{E}+06$ \\
\hline 84 & $M$ & 5 & - & Cologne & Morning & - & - & - & 38,2 & $1,42 E+01$ & - & - & - & 22,47 & $5,54 \mathrm{E}+05$ \\
\hline 84 & $M$ & 5 & - & Cologne & During day & - & - & - & 39,21 & $7,21 \mathrm{E}+00$ & - & - & - & 26,33 & $4,14 \mathrm{E}+04$ \\
\hline 85 & M & 4 & - & Cologne & Morning & - & - & - & 21,07 & $1,42 \mathrm{E}+06$ & - & - & - & 19,4 & $4,36 \mathrm{E}+06$ \\
\hline 85 & M & 4 & - & Cologne & During day & - & - & - & 19,8 & $3,33 \mathrm{E}+06$ & - & - & - & 17,68 & $1,38 \mathrm{E}+07$ \\
\hline 87 & $\mathrm{~F}$ & - & - & Cologne & Morning & - & - & - & 30,74 & $2,14 \mathrm{E}+03$ & - & - & - & 25,99 & $5,20 \mathrm{E}+04$ \\
\hline 87 & $\mathrm{~F}$ & - & - & Cologne & During day & - & - & - & 40,28 & $3,51 \mathrm{E}+00$ & - & - & - & 30,69 & $2,21 E+03$ \\
\hline 88 & $\mathrm{~F}$ & 8 & - & Cologne & Morning & - & - & - & 34,91 & $1,30 \mathrm{E}+02$ & - & - & - & 19,15 & $5,15 \mathrm{E}+06$ \\
\hline 88 & $\mathrm{~F}$ & 8 & - & Cologne & During day & - & - & - & NEG & $0,00 \mathrm{E}+00$ & - & - & - & 34,66 & $1,53 \mathrm{E}+02$ \\
\hline 90 & $\mathrm{~F}$ & 11 & - & Cologne & Morning & - & - & - & 39,98 & $4,30 \mathrm{E}+00$ & - & - & - & 32,46 & $6,73 \mathrm{E}+02$ \\
\hline 91 & $\mathrm{~F}$ & 6 & - & Cologne & Morning & - & - & - & 34,51 & $1,70 \mathrm{E}+02$ & - & - & - & 15,73 & $5,13 E+07$ \\
\hline
\end{tabular}




\section{Extended data Table 1a}

\begin{tabular}{|c|c|c|c|c|c|c|c|c|c|c|c|c|c|c|c|}
\hline \multicolumn{4}{|c|}{ General information } & \multicolumn{2}{|c|}{ Sampling information } & \multicolumn{5}{|c|}{ Lolli-swab } & \multicolumn{5}{|c|}{ Np-/Op-swab } \\
\hline ID & Gender & $\begin{array}{c}\begin{array}{c}\text { Days } \\
\text { after }\end{array} \\
\text { symptom } \\
\text { onset }\end{array}$ & $\begin{array}{c}\text { Days } \\
\text { after } \\
\text { first } \\
\text { positive } \\
\text { PCR }\end{array}$ & $\begin{array}{c}\text { Side } \\
\text { of } \\
\text { sampling }\end{array}$ & $\begin{array}{l}\text { Sampling } \\
\text { time }\end{array}$ & Orf & $\mathbf{E}$ & $\mathbf{N}$ & $\begin{array}{c}\text { RdRp/ } \\
\text { N genes }\end{array}$ & Viral load & Orf & $\mathbf{E}$ & $\mathbf{N}$ & $\begin{array}{c}\text { RdRp/ } \\
\text { N genes }\end{array}$ & $\begin{array}{l}\text { Viral } \\
\text { load }\end{array}$ \\
\hline 91 & $\mathrm{~F}$ & 6 & - & Cologne & During day & - & - & - & 29,1 & $6,43 \mathrm{E}+03$ & - & - & - & 15,28 & $6,94 \mathrm{E}+07$ \\
\hline 92 & M & 7 & - & Cologne & Morning & - & - & - & 30,73 & $2,15 \mathrm{E}+03$ & - & - & - & 24,71 & $1,23 E+05$ \\
\hline 92 & M & 7 & - & Cologne & During day & - & - & - & 37,39 & $2,45 \mathrm{E}+01$ & - & - & - & 24,65 & $1,28 \mathrm{E}+05$ \\
\hline 93 & $\mathrm{~F}$ & 5 & - & Cologne & Morning & - & - & - & 22,87 & $4,23 \mathrm{E}+05$ & - & - & - & 16,75 & $2,59 \mathrm{E}+07$ \\
\hline 94 & $\mathrm{~F}$ & 10 & - & Cologne & Morning & - & - & - & 37,16 & $2,86 \mathrm{E}+01$ & - & - & - & 31,25 & $1,52 \mathrm{E}+03$ \\
\hline 95 & M & 6 & - & Cologne & Morning & - & - & - & 29,85 & $3,89 \mathrm{E}+03$ & - & - & - & 24,2 & $1,73 E+05$ \\
\hline 97 & M & 6 & - & Cologne & Morning & - & - & - & 28,08 & $1,28 \mathrm{E}+04$ & - & - & - & 30,87 & $1,96 \mathrm{E}+03$ \\
\hline 98 & M & - & - & Cologne & Morning & - & - & - & 20,8 & $1,70 \mathrm{E}+06$ & - & - & - & 18,63 & $7,31 E+06$ \\
\hline 98 & M & - & - & Cologne & During day & - & - & - & NEG & $0,00 \mathrm{E}+00$ & - & - & - & 32,02 & $9,04 \mathrm{E}+02$ \\
\hline 99 & $\mathrm{~F}$ & 7 & - & Cologne & Morning & - & 32,56 & - & - & $4,14 \mathrm{E}+03$ & - & 28,01 & - & - & $1,36 \mathrm{E}+05$ \\
\hline 100 & M & 7 & - & Cologne & Morning & - & 33,8 & - & - & $1,60 \mathrm{E}+03$ & - & 28,13 & - & - & $1,24 \mathrm{E}+05$ \\
\hline 102 & M & 8 & - & Cologne & Morning & - & 31,53 & - & - & $9,13 \mathrm{E}+03$ & - & 29,19 & - & - & $5,51 \mathrm{E}+04$ \\
\hline 103 & $\mathrm{~F}$ & 11 & - & Cologne & Morning & - & 35,53 & - & - & $4,23 E+02$ & - & 32,85 & - & - & $3,31 E+03$ \\
\hline 104 & $M$ & 3 & - & Cologne & Morning & - & 33,27 & - & - & $2,40 \mathrm{E}+03$ & - & 35,71 & - & - & $3,69 \mathrm{E}+02$ \\
\hline 105 & M & 6 & - & Cologne & Morning & NEG & - & - & - & $0,00 \mathrm{E}+00$ & - & 36,92 & - & - & $1,46 \mathrm{E}+02$ \\
\hline 106 & $\mathrm{~F}$ & 8 & - & Cologne & Morning & - & 37,3 & - & - & $1,09 \mathrm{E}+02$ & - & 34,77 & - & - & $7,59 \mathrm{E}+02$ \\
\hline 107 & $\mathrm{~F}$ & 9 & - & Cologne & Morning & NEG & - & - & - & $0,00 \mathrm{E}+00$ & 37,49 & 37,49 & - & - & $9,39 \mathrm{E}+01$ \\
\hline 108 & M & 9 & - & Cologne & Morning & - & - & - & 33,61 & $3,11 \mathrm{E}+02$ & - & - & - & 27,04 & $2,57 \mathrm{E}+04$ \\
\hline 109 & M & 8 & - & Cologne & Morning & - & - & - & 28,87 & $7,51 \mathrm{E}+03$ & - & - & - & 29,64 & $4,47 \mathrm{E}+03$ \\
\hline 115 & M & 5 & - & Cologne & Morning & 32,32 & 34,19 & - & - & $1,18 \mathrm{E}+03$ & 30,63 & 30,68 & - & - & $1,75 \mathrm{E}+04$ \\
\hline 116 & $\mathrm{~F}$ & 1 & - & Cologne & Morning & - & 32,15 & - & - & $5,67 \mathrm{E}+03$ & 34,97 & 36,88 & - & - & $1,50 \mathrm{E}+02$ \\
\hline 118 & $\mathrm{~F}$ & - & - & Cologne & Morning & 32,43 & 33,2 & - & - & $2,53 \mathrm{E}+03$ & 33,64 & 33,83 & - & - & $1,56 \mathrm{E}+03$ \\
\hline 119 & $\mathrm{~F}$ & 1 & - & Cologne & Morning & 29,81 & 30,56 & - & - & $1,92 \mathrm{E}+04$ & 24,08 & 24,02 & - & - & $2,92 \mathrm{E}+06$ \\
\hline 120 & $\mathrm{~F}$ & 4 & - & Cologne & Morning & 19,85 & 20,09 & - & - & $5,98 \mathrm{E}+07$ & 23,25 & 23,14 & - & - & $5,74 \mathrm{E}+06$ \\
\hline 121 & $M$ & 0 & - & Cologne & Morning & 29,54 & 30,24 & - & - & $2,46 \mathrm{E}+04$ & 28,01 & 28,04 & - & - & $1,33 \mathrm{E}+05$ \\
\hline 122 & M & - & - & Cologne & Morning & 28,62 & 28,84 & - & - & $7,21 \mathrm{E}+04$ & 27,61 & 27,49 & - & - & $2,03 E+05$ \\
\hline 123 & M & 2 & - & Cologne & Morning & 29,54 & 30,78 & - & - & $1,62 \mathrm{E}+04$ & 33,19 & 34,03 & - & - & $1,34 \mathrm{E}+03$ \\
\hline 127 & M & 2 & - & Cologne & Morning & 32,18 & 32,88 & - & - & $3,24 \mathrm{E}+03$ & 27,26 & 27,28 & - & - & $2,39 E+05$ \\
\hline 130 & $\mathrm{~F}$ & NA & NA & Cologne & Morning & 34,1 & 32,56 & - & - & $4,14 \mathrm{E}+03$ & NEG & NEG & - & & $0,00 \mathrm{E}+00$ \\
\hline 132 & $M$ & 7 & - & Cologne & Morning & $\mathrm{NEG}$ & 33,27 & - & - & $2,40 \mathrm{E}+03$ & 33,96 & 35,26 & - & - & $5,21 \mathrm{E}+02$ \\
\hline 133 & M & 11 & - & Cologne & Morning & NEG & NEG & - & - & $0,00 \mathrm{E}+00$ & 32,71 & 33,8 & - & - & $1,60 \mathrm{E}+03$ \\
\hline 134 & $\mathrm{~F}$ & 6 & - & Cologne & Morning & 31,71 & 32,85 & - & - & $3,31 \mathrm{E}+03$ & 25,05 & 25,35 & - & - & $1,05 \mathrm{E}+06$ \\
\hline 135 & $\mathrm{~F}$ & 7 & - & Cologne & Morning & 29,84 & 30,79 & - & - & $1,61 \mathrm{E}+04$ & 23,89 & 23,76 & - & - & $3,57 \mathrm{E}+06$ \\
\hline 136 & $\mathrm{~F}$ & 7 & - & Cologne & Morning & 30,61 & 31,9 & - & - & $6,87 \mathrm{E}+03$ & 30,14 & 30,14 & - & - & $2,66 \mathrm{E}+04$ \\
\hline 137 & M & 4 & - & Cologne & Morning & 32,53 & 33,8 & - & - & $1,60 \mathrm{E}+03$ & 24,12 & 24,17 & - & - & $2,60 \mathrm{E}+06$ \\
\hline 138 & M & 4 & - & Cologne & Morning & 29,35 & 29,77 & - & - & $3,53 \mathrm{E}+04$ & 28,62 & 28,48 & - & - & $9,51 \mathrm{E}+04$ \\
\hline 139 & $\mathrm{~F}$ & 2 & - & Cologne & Morning & 30,08 & 30,32 & - & - & $2,31 \mathrm{E}+04$ & 18,28 & 17,68 & - & - & $3,80 \mathrm{E}+08$ \\
\hline 141 & $M$ & 7 & - & Cologne & Morning & NEG & NEG & - & - & $0,00 \mathrm{E}+00$ & 34,26 & 36,97 & - & - & $1,40 \mathrm{E}+02$ \\
\hline 144 & $\mathrm{~F}$ & NA & NA & Cologne & Morning & 22,4 & 22,14 & - & - & $1,24 \mathrm{E}+07$ & NEG & NEG & - & & $0,00 \mathrm{E}+00$ \\
\hline 145 & M & 5 & - & Cologne & Morning & 30,04 & 31,01 & - & - & $1,36 \mathrm{E}+04$ & 19,62 & 19,73 & - & - & $7,88 \mathrm{E}+07$ \\
\hline 148 & $\mathrm{~F}$ & 7 & - & Cologne & Morning & NEG & 35 & - & - & $6,36 \mathrm{E}+02$ & 31,19 & 28,41 & - & - & $1,00 \mathrm{E}+05$ \\
\hline 150 & M & 10 & - & Cologne & Morning & NEG & $N E G$ & - & - & $0,00 \mathrm{E}+00$ & 35,7 & 36,32 & - & - & $2,31 E+02$ \\
\hline 153 & $\mathrm{~F}$ & 5 & - & Cologne & Morning & 30,31 & 30,88 & - & - & $1,50 \mathrm{E}+04$ & 22,68 & 22,48 & - & - & $9,53 \mathrm{E}+06$ \\
\hline 155 & $\mathrm{~F}$ & - & - & Cologne & Morning & NEG & 33,8 & - & - & $1,60 \mathrm{E}+03$ & NEG & NEG & - & - & $0,00 \mathrm{E}+00$ \\
\hline 158 & M & 8 & - & Cologne & Morning & 32,28 & 33,19 & - & - & $2,55 E+03$ & 26,37 & 26,55 & - & - & $4,18 \mathrm{E}+05$ \\
\hline 159 & M & 3 & - & Cologne & Morning & NEG & 31,53 & - & - & $9,13 \mathrm{E}+03$ & 33,49 & 35,29 & - & - & $5,09 \mathrm{E}+02$ \\
\hline 160 & M & 10 & - & Cologne & Morning & NEG & NEG & - & - & $0,00 \mathrm{E}+00$ & NEG & 37,38 & - & - & $1,02 \mathrm{E}+02$ \\
\hline 161 & M & 12 & - & Cologne & Morning & 31,05 & 31,78 & - & - & $7,54 \mathrm{E}+03$ & 32,56 & 34,99 & - & - & $6,41 \mathrm{E}+02$ \\
\hline 162 & $\mathrm{~F}$ & - & - & Cologne & Morning & NEG & 37,74 & - & - & $7,75 \mathrm{E}+01$ & 35,01 & 35,01 & - & - & $6,31 E+02$ \\
\hline 163 & $\mathrm{~F}$ & 10 & - & Cologne & Morning & $\mathrm{NEG}$ & 35,53 & - & - & $4,23 \mathrm{E}+02$ & 33 & 34,27 & - & - & $1,11 \mathrm{E}+03$ \\
\hline 166 & $\mathrm{~F}$ & 4 & 2 & Cologne & Morning & NEG & NEG & - & - & $0,00 \mathrm{E}+00$ & 31,81 & 34,01 & - & - & $1,36 \mathrm{E}+03$ \\
\hline 166 & $\mathrm{~F}$ & 4 & 2 & Cologne & During day & NEG & $N E G$ & - & - & $0,00 \mathrm{E}+00$ & 32,02 & 33,15 & - & - & $6,27 \mathrm{E}+03$ \\
\hline 167 & $\mathrm{~F}$ & 3 & 2 & Cologne & Morning & 32,27 & 34,1 & - & - & $1,27 \mathrm{E}+03$ & 29,42 & 29,57 & - & - & $4,12 \mathrm{E}+04$ \\
\hline 167 & $\mathrm{~F}$ & 3 & 2 & Cologne & During day & NEG & NEG & - & - & $0,00 \mathrm{E}+00$ & 28,77 & 28,8 & - & - & $7,61 \mathrm{E}+04$ \\
\hline 168 & M & 6 & 2 & Cologne & Morning & 31,77 & 33,03 & - & - & $2,89 \mathrm{E}+03$ & 28,07 & 27,5 & - & - & $2,02 \mathrm{E}+05$ \\
\hline 168 & M & 6 & 2 & Cologne & During day & 27,27 & 27,96 & - & - & $2,41 \mathrm{E}+05$ & 19,93 & 20,06 & - & - & $6,76 \mathrm{E}+07$ \\
\hline 169 & $\mathrm{~F}$ & 6 & 2 & Cologne & Morning & 33,81 & 35,08 & - & - & $5,98 \mathrm{E}+02$ & 29,77 & 30,65 & - & - & $1,80 \mathrm{E}+04$ \\
\hline 169 & $\mathrm{~F}$ & 6 & 2 & Cologne & During day & 32,58 & 34,93 & - & - & $4,08 \mathrm{E}+03$ & 24,42 & 24,52 & - & - & $2,15 \mathrm{E}+06$ \\
\hline 170 & M & 2 & 2 & Cologne & Morning & - & - & - & 20,8 & $1,70 \mathrm{E}+06$ & - & - & - & 18,63 & $7,31 \mathrm{E}+06$ \\
\hline 171 & $\mathrm{~F}$ & - & 2 & Cologne & Morning & - & - & - & NEG & $0,00 \mathrm{E}+00$ & - & - & - & 35,32 & $9,84 \mathrm{E}+01$ \\
\hline 172 & $\mathrm{~F}$ & 5 & 3 & Cologne & Morning & - & - & - & 36,52 & $4,39 \mathrm{E}+01$ & - & - & - & 20,09 & $2,74 \mathrm{E}+06$ \\
\hline 173 & $\mathrm{~F}$ & 6 & 3 & Cologne & Morning & - & - & - & NEG & $0,00 \mathrm{E}+00$ & - & - & - & 33,03 & $4,59 \mathrm{E}+02$ \\
\hline 174 & $\mathrm{~F}$ & - & 2 & Cologne & Morning & - & - & - & NEG & $0,00 \mathrm{E}+00$ & - & - & - & 34,45 & $1,77 \mathrm{E}+02$ \\
\hline 175 & $\mathrm{~F}$ & 9 & 2 & Cologne & Morning & - & - & - & 32,36 & $7,19 \mathrm{E}+02$ & - & - & - & 38,16 & $1,46 \mathrm{E}+01$ \\
\hline 176 & $\mathrm{~F}$ & 7 & 2 & Cologne & Morning & - & - & - & 26,85 & $2,92 \mathrm{E}+04$ & - & - & - & 26,57 & $3,52 E+04$ \\
\hline 176 & $\mathrm{~F}$ & 7 & 2 & Cologne & During day & - & - & - & NEG & $0,00 \mathrm{E}+00$ & - & - & - & 28,99 & $6,92 \mathrm{E}+03$ \\
\hline 177 & $\mathrm{~F}$ & 2 & 2 & Cologne & Morning & - & - & - & 32,92 & $4,94 \mathrm{E}+02$ & - & - & - & 27,33 & $2,11 E+04$ \\
\hline 177 & $\mathrm{~F}$ & 2 & 2 & Cologne & During day & - & - & - & 38,4 & $1,24 \mathrm{E}+01$ & - & - & - & 25,11 & $9,39 \mathrm{E}+04$ \\
\hline 178 & $\mathrm{~F}$ & 5 & 2 & Cologne & Morning & - & - & - & 24,63 & $1,30 \mathrm{E}+05$ & - & - & - & 15,94 & $4,46 \mathrm{E}+07$ \\
\hline 178 & $\mathrm{~F}$ & 5 & 2 & Cologne & During day & - & - & - & 28,77 & $8,03 \mathrm{E}+03$ & - & - & - & 17,11 & $2,03 E+07$ \\
\hline 181 & $\mathrm{~F}$ & 4 & 2 & Cologne & Morning & - & - & - & NEG & $0,00 \mathrm{E}+00$ & - & - & - & 31,62 & $1,18 \mathrm{E}+03$ \\
\hline 181 & $\mathrm{~F}$ & 4 & 2 & Cologne & During day & - & - & - & NEG & $0,00 \mathrm{E}+00$ & - & - & - & 31,14 & $1,63 \mathrm{E}+03$ \\
\hline 182 & $\mathrm{~F}$ & 7 & 2 & Cologne & Morning & - & - & - & 38,91 & $8,82 \mathrm{E}+00$ & - & - & - & 26,71 & $3,20 \mathrm{E}+04$ \\
\hline
\end{tabular}




\section{Extended data Table 1a}

\begin{tabular}{|c|c|c|c|c|c|c|c|c|c|c|c|c|c|c|c|}
\hline \multicolumn{4}{|c|}{ General information } & \multicolumn{2}{|c|}{ Sampling information } & \multicolumn{5}{|c|}{ Lolli-swab } & \multicolumn{5}{|c|}{ Np-/Op-swab } \\
\hline ID & Gender & $\begin{array}{l}\text { Days } \\
\text { after } \\
\text { symptom } \\
\text { onset }\end{array}$ & $\begin{array}{c}\text { Days } \\
\text { after } \\
\text { first } \\
\text { positive } \\
\text { PCR }\end{array}$ & $\begin{array}{c}\text { Side } \\
\text { of } \\
\text { sampling }\end{array}$ & $\begin{array}{l}\text { Sampling } \\
\text { time }\end{array}$ & Orf & E & $\mathbf{N}$ & $\begin{array}{c}\text { RdRp/ } \\
\text { N genes }\end{array}$ & Viral load & Orf & $\mathbf{E}$ & $\mathbf{N}$ & $\begin{array}{c}\text { RdRp/ } \\
\text { N genes }\end{array}$ & $\begin{array}{l}\text { Viral } \\
\text { load }\end{array}$ \\
\hline 182 & $\mathrm{~F}$ & 7 & 2 & Cologne & During day & - & - & - & NEG & $0,00 \mathrm{E}+00$ & - & - & - & 27,57 & $1,80 E+04$ \\
\hline 184 & $M$ & 5 & 2 & Cologne & Morning & - & - & - & 30,79 & $2,07 \mathrm{E}+03$ & - & - & - & 17,47 & $1,59 \mathrm{E}+07$ \\
\hline 184 & M & 5 & 2 & Cologne & During day & - & - & - & 35,44 & $9,08 \mathrm{E}+01$ & - & - & - & 19,8 & $3,33 E+06$ \\
\hline 185 & $F$ & - & 0 & Cologne & Morning & - & - & - & 25,76 & $6,07 \mathrm{E}+04$ & - & - & - & 21,35 & $1,18 \mathrm{E}+06$ \\
\hline 185 & $\mathrm{~F}$ & - & 0 & Cologne & During day & - & - & - & 26,77 & $3,08 \mathrm{E}+04$ & - & - & - & 25,78 & $5,99 \mathrm{E}+04$ \\
\hline 186 & M & 7 & 2 & Cologne & Morning & - & - & - & 32,34 & $7,29 \mathrm{E}+02$ & - & - & - & 24,27 & $1,65 \mathrm{E}+05$ \\
\hline 186 & M & 7 & 2 & Cologne & During day & - & - & - & 28,48 & $9,76 \mathrm{E}+03$ & - & - & - & 28,87 & $7,51 \mathrm{E}+03$ \\
\hline 187 & $M$ & 11 & 2 & Cologne & Morning & - & 34,69 & - & - & $8,07 \mathrm{E}+02$ & - & 34,1 & - & - & $1,27 \mathrm{E}+03$ \\
\hline 188 & $F$ & - & 0 & Cologne & Morning & - & 33,97 & - & - & $1,40 \mathrm{E}+03$ & - & 24,6 & - & - & $1,87 \mathrm{E}+06$ \\
\hline 189 & $M$ & - & 0 & Cologne & Morning & - & 27,08 & - & - & $2,79 \mathrm{E}+05$ & - & 19,53 & - & - & $9,19 \mathrm{E}+07$ \\
\hline 190 & $\mathrm{~F}$ & 5 & 2 & Cologne & Morning & - & 31,28 & - & - & $1,11 \mathrm{E}+04$ & - & 22,75 & - & - & $7,75 \mathrm{E}+06$ \\
\hline 193 & $\mathrm{~F}$ & 5 & 2 & Cologne & Morning & - & 34,04 & - & - & $1,33 \mathrm{E}+03$ & - & 33,85 & - & - & $1,54 \mathrm{E}+03$ \\
\hline 194 & $\mathrm{~F}$ & 4 & 2 & Cologne & Morning & - & 24,08 & - & - & $2,79 \mathrm{E}+06$ & - & 28,44 & - & - & $9,80 \mathrm{E}+04$ \\
\hline 195 & $\mathrm{~F}$ & 8 & 2 & Cologne & Morning & - & 32,08 & - & - & $5,99 \mathrm{E}+03$ & - & 23,34 & - & - & $4,92 \mathrm{E}+06$ \\
\hline 196 & $\mathrm{~F}$ & 2 & 2 & Cologne & Morning & - & 32,15 & - & - & $5,67 \mathrm{E}+03$ & - & 26,67 & - & - & $3,82 E+05$ \\
\hline 197 & $M$ & 3 & - & Cologne & Morning & - & - & - & 39,63 & $5,43 \mathrm{E}+00$ & - & - & - & 36 & $6,23 E+01$ \\
\hline 198 & $F$ & 1 & - & Cologne & Morning & - & - & - & 33,8 & $2,73 \mathrm{E}+02$ & - & - & - & 33,5 & $3,34 \mathrm{E}+02$ \\
\hline 199 & $\mathrm{~F}$ & 5 & - & Cologne & Morning & - & - & - & 29,35 & $5,44 \mathrm{E}+03$ & - & - & - & 33,48 & $3,39 E+02$ \\
\hline 225 & $M$ & 2 & - & Tabasco & During day & 29,73 & 29,55 & 29,84 & - & $2,03 \mathrm{E}+04$ & 15,67 & 10,47 & 15,06 & - & $5,78 \mathrm{E}+08$ \\
\hline 226 & $\mathrm{~F}$ & 9 & - & Tabasco & During day & 34,45 & NEG & 35,01 & - & $5,61 \mathrm{E}+02$ & 27 & 21,71 & 26,12 & - & $2,68 \mathrm{E}+05$ \\
\hline 227 & $M$ & 2 & - & Tabasco & During day & 25,54 & 25,31 & 26,97 & - & $1,49 \mathrm{E}+05$ & 11,66 & 7,6 & 11,06 & - & $9,28 \mathrm{E}+09$ \\
\hline 228 & M & 6 & - & Tabasco & During day & 25,14 & 24,09 & 24,88 & - & $6,34 \mathrm{E}+05$ & 21,95 & 16,66 & 22,03 & - & $4,58 \mathrm{E}+06$ \\
\hline 229 & $\mathrm{~F}$ & 10 & - & Tabasco & During day & NEG & NEG & NEG & - & $0,00 \mathrm{E}+00$ & 36,26 & NEG & 33,69 & - & $1,40 \mathrm{E}+03$ \\
\hline 230 & $M$ & 6 & - & Tabasco & During day & 34,19 & NEG & 35,42 & - & $4,22 \mathrm{E}+02$ & 26,1 & 22,46 & 25,87 & - & $3,19 \mathrm{E}+05$ \\
\hline 231 & $M$ & 7 & - & Tabasco & During day & 32,53 & 32,78 & 32,67 & - & $2,85 \mathrm{E}+03$ & 23,02 & 22,11 & 24,47 & - & $8,43 E+05$ \\
\hline 232 & $M$ & 7 & - & Tabasco & During day & 32,38 & 34,16 & 31,83 & - & $5,10 \mathrm{E}+03$ & 28,24 & 27,6 & 26,23 & - & $2,48 \mathrm{E}+05$ \\
\hline 233 & M & 4 & - & Tabasco & During day & 27,75 & 27,33 & 28,15 & - & $6,56 \mathrm{E}+04$ & 16,28 & 14,98 & 15,29 & - & $4,93 \mathrm{E}+08$ \\
\hline 234 & $F$ & 4 & - & Tabasco & During day & NEG & NEG & NEG & - & $0,00 \mathrm{E}+00$ & NEG & NEG & 32,67 & - & $2,85 \mathrm{E}+03$ \\
\hline 235 & $M$ & 4 & - & Tabasco & During day & 29,31 & 28,99 & 28,83 & - & $4,09 \mathrm{E}+04$ & 13,7 & 12,43 & 12,95 & - & $2,50 \mathrm{E}+09$ \\
\hline 236 & $\mathrm{~F}$ & 7 & - & Tabasco & During day & 29,58 & 28,87 & 28,92 & - & $3,84 \mathrm{E}+04$ & 22,59 & 22,25 & 23,19 & - & $2,05 E+06$ \\
\hline 237 & $M$ & 8 & - & Tabasco & During day & 30,33 & 29,83 & 29,91 & - & $1,93 \mathrm{E}+04$ & 24,64 & 24,13 & 25,21 & - & $5,04 \mathrm{E}+05$ \\
\hline 238 & $F$ & 10 & - & Tabasco & During day & 28,97 & 28,15 & 28,67 & - & $4,57 \mathrm{E}+04$ & 23,93 & 23,68 & 25,3 & - & $4,74 \mathrm{E}+05$ \\
\hline 239 & $M$ & 6 & - & Tabasco & During day & 31,4 & 30,77 & 32,22 & - & $3,89 \mathrm{E}+03$ & 24,44 & 25,6 & 26,39 & - & $2,22 \mathrm{E}+05$ \\
\hline 240 & $\mathrm{~F}$ & 5 & - & Tabasco & During day & NEG & NEG & 34,05 & - & $1,09 \mathrm{E}+03$ & 33,5 & 33,27 & 32,17 & - & $4,03 E+03$ \\
\hline 241 & $F$ & 6 & - & Tabasco & During day & $N E G$ & NEG & NEG & - & $0,00 \mathrm{E}+00$ & 29,01 & 27,44 & 30,47 & - & $1,31 E+04$ \\
\hline 242 & $M$ & 7 & - & Tabasco & During day & 31,86 & 28,82 & 30,3 & - & $1,47 \mathrm{E}+04$ & 18,2 & 15,63 & 18,7 & - & $4,62 \mathrm{E}+07$ \\
\hline 243 & $M$ & 3 & - & Tabasco & During day & $\mathrm{NEG}$ & NEG & NEG & - & $0,00 \mathrm{E}+00$ & 30,38 & 28,72 & 30,81 & - & $1,03 \mathrm{E}+04$ \\
\hline 244 & $F$ & 6 & - & Tabasco & During day & $\mathrm{NEG}$ & NEG & NEG & - & $0,00 \mathrm{E}+00$ & 34,09 & NEG & 33,47 & - & $1,63 \mathrm{E}+03$ \\
\hline 245 & $M$ & 6 & - & Tabasco & During day & NEG & NEG & NEG & - & $0,00 \mathrm{E}+00$ & 31,4 & NEG & 31,58 & - & $6,06 \mathrm{E}+03$ \\
\hline 246 & $\mathrm{~F}$ & 5 & - & Tabasco & During day & NEG & NEG & 36,33 & - & $2,24 \mathrm{E}+02$ & 22,48 & 17,66 & 19,86 & - & $2,07 \mathrm{E}+07$ \\
\hline 247 & $M$ & 6 & - & Tabasco & During day & 25,51 & 24,78 & 25,42 & - & $4,36 \mathrm{E}+05$ & 24,32 & 21,5 & 22,89 & - & $2,52 E+06$ \\
\hline 248 & M & NA & - & Tabasco & During day & $\mathrm{NEG}$ & NEG & NEG & - & $0,00 \mathrm{E}+00$ & 32,45 & NEG & 29,17 & - & $3,23 E+04$ \\
\hline 249 & $\mathrm{~F}$ & 4 & - & Tabasco & During day & 34 & NEG & 32,84 & - & $2,53 \mathrm{E}+03$ & 27,22 & 26,17 & 26,29 & - & $2,38 \mathrm{E}+05$ \\
\hline 250 & $\mathrm{~F}$ & 5 & - & Tabasco & During day & 26,95 & 26,97 & 26,05 & - & $2,82 \mathrm{E}+05$ & 26,43 & 23,85 & 23,82 & - & $1,32 \mathrm{E}+06$ \\
\hline 251 & $M$ & 7 & - & Tabasco & During day & 33,27 & 31,35 & 31,77 & - & $5,32 \mathrm{E}+03$ & 31,06 & 30,3 & 29,12 & - & $3,34 \mathrm{E}+04$ \\
\hline 252 & $M$ & NA & - & Tabasco & During day & 31,19 & 30,95 & 28,98 & - & $3,69 \mathrm{E}+04$ & 29,99 & 28,47 & 27,67 & - & $9,15 \mathrm{E}+04$ \\
\hline 253 & $\mathrm{~F}$ & 4 & - & Tabasco & During day & 31,2 & 30,45 & 31,65 & - & $5,78 \mathrm{E}+03$ & 19,34 & 16,82 & 18,9 & - & $4,02 E+07$ \\
\hline 254 & M & 6 & - & Tabasco & During day & 21,29 & 21,06 & 21,14 & - & $8,50 \mathrm{E}+06$ & 16,43 & 14,42 & 15,51 & - & $4,23 \mathrm{E}+08$ \\
\hline 255 & $M$ & 3 & - & Tabasco & During day & NEG & NEG & 36,82 & - & $1,60 \mathrm{E}+02$ & 20,3 & 19,26 & 18,83 & - & $4,22 \mathrm{E}+07$ \\
\hline 256 & $F$ & 7 & - & Tabasco & During day & 31,46 & 27,42 & 30,89 & - & $9,79 \mathrm{E}+03$ & 26,33 & 25,71 & 27,25 & - & $1,22 \mathrm{E}+05$ \\
\hline 257 & $M$ & 7 & - & Tabasco & During day & 33,74 & NEG & 32,8 & - & $2,60 \mathrm{E}+03$ & 28,17 & 27,7 & 28,32 & - & $5,83 E+04$ \\
\hline 258 & $M$ & 4 & - & Tabasco & During day & NEG & NEG & NEG & - & $0,00 \mathrm{E}+00$ & 25,14 & 24,41 & 24,19 & - & $1,02 E+06$ \\
\hline 259 & $\mathrm{~F}$ & NA & - & Tabasco & During day & NEG & NEG & NEG & - & $0,00 \mathrm{E}+00$ & 34,58 & NEG & 33,34 & - & $1,79 E+03$ \\
\hline 260 & $\mathrm{~F}$ & 4 & - & Tabasco & During day & NEG & NEG & NEG & - & $0,00 \mathrm{E}+00$ & 35,55 & 29,93 & 31,56 & - & $6,15 \mathrm{E}+03$ \\
\hline 261 & M & NA & - & Tabasco & During day & $N E G$ & NEG & NEG & - & $0,00 \mathrm{E}+00$ & 21,72 & 18,46 & 21,6 & - & $6,18 \mathrm{E}+06$ \\
\hline 262 & $\mathrm{~F}$ & 0 & - & Tabasco & During day & NEG & NEG & NEG & - & $0,00 \mathrm{E}+00$ & 32,28 & 27,98 & 29,42 & - & $2,72 \mathrm{E}+04$ \\
\hline 263 & $M$ & 7 & - & Tabasco & During day & NEG & NEG & $N E G$ & - & $0,00 \mathrm{E}+00$ & 28,36 & 26,75 & 27,93 & - & $7,64 \mathrm{E}+04$ \\
\hline 264 & $M$ & 0 & - & Tabasco & During day & 33,83 & 34,76 & 32,79 & - & $2,62 \mathrm{E}+03$ & 20,97 & 18,8 & 20,95 & - & $9,70 \mathrm{E}+06$ \\
\hline 265 & $M$ & 3 & - & Tabasco & During day & 26,73 & 26,81 & 26,51 & - & $2,05 E+05$ & 26,84 & 23,73 & 25,36 & - & $4,54 \mathrm{E}+05$ \\
\hline 266 & $\mathrm{~F}$ & NA & - & Tabasco & During day & NEG & NEG & NEG & - & $0,00 \mathrm{E}+00$ & 31,57 & 29,5 & 29,76 & - & $2,14 \mathrm{E}+04$ \\
\hline 267 & $F$ & 7 & - & Tabasco & During day & 20,81 & 18,28 & 22,24 & - & $3,96 \mathrm{E}+06$ & 31,18 & 35,62 & 31,13 & - & $8,29 E+03$ \\
\hline 268 & NA & NA & - & Tabasco & During day & 33,89 & NEG & 33,92 & - & $1,20 \mathrm{E}+03$ & 24,52 & 24,49 & 25,16 & - & $5,22 \mathrm{E}+05$ \\
\hline 269 & $\mathrm{~F}$ & 12 & - & Tabasco & During day & NEG & NEG & 36,47 & - & $2,04 \mathrm{E}+02$ & 31,18 & 28,94 & 31,69 & - & $5,62 \mathrm{E}+03$ \\
\hline 270 & M & 4 & - & Tabasco & During day & $\mathrm{NEG}$ & NEG & NEG & - & $0,00 \mathrm{E}+00$ & 24,61 & 21,02 & 24,22 & - & $1,00 E+06$ \\
\hline 271 & $\mathrm{~F}$ & 4 & - & Tabasco & During day & NEG & NEG & NEG & - & $0,00 \mathrm{E}+00$ & 26,77 & 24,65 & 27,55 & - & $9,94 \mathrm{E}+04$ \\
\hline 272 & $\mathrm{~F}$ & 5 & - & Tabasco & During day & NEG & NEG & NEG & - & $0,00 \mathrm{E}+00$ & 20,74 & 18,42 & 22,37 & - & $3,62 E+06$ \\
\hline 273 & $M$ & 13 & - & Tabasco & During day & NEG & NEG & 34,78 & - & $6,58 \mathrm{E}+02$ & 33,59 & NEG & 30,75 & - & $1,08 \mathrm{E}+04$ \\
\hline 274 & $\mathrm{~F}$ & 14 & - & Tabasco & During day & NEG & NEG & NEG & - & $0,00 \mathrm{E}+00$ & 28,42 & 27,22 & 26,98 & - & $1,48 \mathrm{E}+05$ \\
\hline 275 & $\mathrm{~F}$ & 12 & - & Tabasco & During day & NEG & NEG & NEG & - & $0,00 \mathrm{E}+00$ & 32,11 & 31,07 & 31,6 & - & $5,98 \mathrm{E}+03$ \\
\hline 276 & $M$ & NA & - & Tabasco & During day & NEG & NEG & NEG & - & $0,00 \mathrm{E}+00$ & 36,39 & 31,48 & 31,1 & - & $8,46 \mathrm{E}+03$ \\
\hline 277 & $\mathrm{~F}$ & NA & - & Tabasco & During day & NEG & NEG & NEG & - & $0,00 \mathrm{E}+00$ & 18,13 & 14,43 & 15,85 & - & $3,34 \mathrm{E}+08$ \\
\hline 278 & $\mathrm{~F}$ & 6 & - & Tabasco & During day & NEG & NEG & NEG & - & $0,00 \mathrm{E}+00$ & 26,39 & 25,23 & 26,23 & - & $2,48 \mathrm{E}+05$ \\
\hline 279 & $\mathrm{~F}$ & 7 & - & Tabasco & During day & NEG & NEG & NEG & - & $0,00 \mathrm{E}+00$ & 35,45 & NEG & 32,74 & - & $2,71 E+03$ \\
\hline
\end{tabular}


medRxiv preprint doi: https://doi.org/10.1101/2022.02.04.22270304; this version posted February 6, 2022. The copyright holder for this preprint (which was not certified by peer review) is the author/funder, who has granted medRxiv a license to display the preprint in

It is made available under a CC-BY-NC-ND 4.0 International license .

\section{Extended data Table 1a}

\begin{tabular}{|c|c|c|c|c|c|c|c|c|c|c|c|c|c|c|c|}
\hline \multicolumn{4}{|c|}{ General information } & \multicolumn{2}{|c|}{ Sampling information } & \multicolumn{5}{|c|}{ Lolli-swab } & \multicolumn{5}{|c|}{ Np-/Op-swab } \\
\hline ID & Gender & $\begin{array}{c}\begin{array}{c}\text { Days } \\
\text { after }\end{array} \\
\text { symptom } \\
\text { onset }\end{array}$ & $\begin{array}{c}\text { Days } \\
\text { after } \\
\text { first } \\
\text { positive } \\
\text { PCR }\end{array}$ & $\begin{array}{c}\text { Side } \\
\text { of } \\
\text { sampling }\end{array}$ & $\begin{array}{l}\text { Sampling } \\
\text { time }\end{array}$ & Orf & $\mathbf{E}$ & $\mathbf{N}$ & $\begin{array}{c}\text { RdRp/ } \\
\text { N genes }\end{array}$ & Viral load & Orf & E & $\mathbf{N}$ & $\begin{array}{c}\text { RdRp/ } \\
\text { N genes }\end{array}$ & $\begin{array}{l}\text { Viral } \\
\text { load }\end{array}$ \\
\hline 280 & $\mathrm{~F}$ & NA & - & Tabasco & During day & 29,55 & 30,16 & 29,35 & - & $2,85 \mathrm{E}+04$ & 28,34 & 26,68 & 26,62 & - & $1,90 \mathrm{E}+05$ \\
\hline 281 & $\mathrm{~F}$ & 5 & - & Tabasco & During day & 33,42 & NEG & 33,34 & - & $1,79 \mathrm{E}+03$ & 14,8 & 14,26 & 14,27 & - & $1,00 \mathrm{E}+09$ \\
\hline 282 & $\mathrm{~F}$ & 3 & - & Tabasco & During day & NEG & NEG & NEG & - & $0,00 \mathrm{E}+00$ & 29,16 & 28,89 & 27,6 & - & $9,60 \mathrm{E}+04$ \\
\hline 283 & $\mathrm{M}$ & 3 & - & Tabasco & During day & NEG & NEG & NEG & - & $0,00 \mathrm{E}+00$ & 28,79 & 28,96 & 27,27 & - & $1,21 \mathrm{E}+05$ \\
\hline 284 & $\mathrm{~F}$ & 2 & - & Tabasco & During day & NEG & NEG & NEG & - & $0,00 \mathrm{E}+00$ & NEG & NEG & 33,09 & - & $2,13 E+03$ \\
\hline 285 & M & 2 & - & Tabasco & During day & NEG & NEG & NEG & - & $0,00 \mathrm{E}+00$ & 35,51 & NEG & 32,91 & - & $2,41 E+03$ \\
\hline 286 & M & 7 & - & Tabasco & During day & NEG & NEG & NEG & - & $0,00 \mathrm{E}+00$ & $N E G$ & NEG & 34,23 & - & $9,64 \mathrm{E}+02$ \\
\hline 287 & $\mathrm{~F}$ & NA & - & Tabasco & During day & NEG & NEG & NEG & - & $0,00 \mathrm{E}+00$ & 20,89 & 20,17 & 20,76 & - & $1,11 \mathrm{E}+07$ \\
\hline 288 & M & 10 & - & Tabasco & During day & NEG & NEG & NEG & - & $0,00 \mathrm{E}+00$ & 36,51 & NEG & 33,31 & - & $1,83 \mathrm{E}+03$ \\
\hline 289 & $\mathrm{~F}$ & 9 & - & Tabasco & During day & $\mathrm{NEG}$ & NEG & NEG & - & $0,00 \mathrm{E}+00$ & 26,05 & 26,42 & 24,78 & - & $6,80 \mathrm{E}+05$ \\
\hline 290 & $\mathrm{M}$ & 6 & - & Tabasco & During day & 37,89 & NEG & 37,46 & - & $1,02 \mathrm{E}+02$ & 22,17 & 21,57 & 21,7 & - & $5,76 \mathrm{E}+06$ \\
\hline 291 & M & 11 & - & Tabasco & During day & $\mathrm{NEG}$ & $\mathrm{NEG}$ & NEG & - & $0,00 \mathrm{E}+00$ & 27,78 & 27,53 & 26,9 & - & $1,56 \mathrm{E}+05$ \\
\hline 292 & $\mathrm{~F}$ & 4 & - & Tabasco & During day & 27,92 & 28,19 & 28,37 & - & $5,63 \mathrm{E}+04$ & 15,31 & 14,23 & 14,59 & - & $8,01 E+08$ \\
\hline 293 & $\mathrm{~F}$ & 6 & - & Tabasco & During day & 31,81 & 33,41 & 31,31 & - & $7,31 \mathrm{E}+03$ & 23,11 & 22,64 & 21,48 & - & $6,71 \mathrm{E}+06$ \\
\hline 294 & $\mathrm{~F}$ & 7 & - & Tabasco & During day & 35,7 & $\mathrm{NEG}$ & 33,19 & - & $1,98 \mathrm{E}+03$ & 25,15 & 25,39 & 24,62 & - & $7,60 \mathrm{E}+05$ \\
\hline 295 & M & 7 & - & Tabasco & During day & 31,73 & 30,35 & 30,32 & - & $1,45 E+04$ & 27,56 & 26,4 & 26,06 & - & $2,80 \mathrm{E}+05$ \\
\hline 296 & $M$ & 10 & - & Tabasco & During day & 35 & NEG & 36,77 & - & $1,65 \mathrm{E}+02$ & 24,48 & 23,81 & 27,64 & - & $9,34 \mathrm{E}+04$ \\
\hline 297 & M & 4 & - & Tabasco & During day & 26,63 & 24,83 & 25,19 & - & $5,11 \mathrm{E}+05$ & 16,27 & 15,39 & 16,39 & - & $2,30 \mathrm{E}+08$ \\
\hline 298 & M & 7 & - & Tabasco & During day & 28,69 & 27,44 & 26,67 & - & $1,83 \mathrm{E}+05$ & 25,57 & 25,93 & 24,86 & - & $6,43 E+05$ \\
\hline 299 & M & 7 & - & Tabasco & During day & 35,14 & NEG & 38,65 & - & $4,49 \mathrm{E}+01$ & 26,8 & 24,3 & 27,33 & - & $1,16 \mathrm{E}+05$ \\
\hline 300 & $M$ & 3 & - & Tabasco & During day & 31,07 & 30,12 & 31,26 & - & $7,57 \mathrm{E}+03$ & 20,9 & 17,49 & 20,7 & - & $1,15 \mathrm{E}+07$ \\
\hline 301 & $F$ & 8 & - & Tabasco & During day & 29,12 & 27,11 & 27,96 & - & $7,48 \mathrm{E}+04$ & 27,53 & 25,23 & 28,03 & - & $7,12 \mathrm{E}+04$ \\
\hline 302 & $\mathrm{M}$ & 7 & & Tabasco & During day & 33,96 & NEG & 33,05 & - & $2,19 \mathrm{E}+03$ & 28,97 & 27,52 & 28,87 & - & $3,98 \mathrm{E}+04$ \\
\hline 303 & $M$ & 6 & - & Tabasco & During day & 34,44 & NEG & 37,78 & - & $8,21 E+01$ & 30,11 & 29,31 & 29,71 & - & $2,22 \mathrm{E}+04$ \\
\hline 304 & $M$ & 4 & - & Tabasco & During day & 30,95 & 36,01 & 31,22 & - & $7,79 \mathrm{E}+03$ & 21,01 & 22,64 & 22,26 & - & $3,91 E+06$ \\
\hline 305 & $\mathrm{~F}$ & 7 & - & Tabasco & During day & 23,82 & 25,63 & 24,41 & - & $8,79 \mathrm{E}+05$ & 20,89 & 22,16 & 22,19 & - & $4,10 E+06$ \\
\hline 306 & M & 0 & - & Tabasco & During day & 27,73 & 26,06 & 27,31 & - & $1,17 \mathrm{E}+05$ & 19,37 & 19,05 & 20,95 & - & $9,70 \mathrm{E}+06$ \\
\hline 307 & $\mathrm{~F}$ & 0 & - & Tabasco & During day & 26,68 & 25,58 & 27,12 & - & $1,34 \mathrm{E}+05$ & 22,21 & 22,08 & 23,44 & - & $1,72 \mathrm{E}+06$ \\
\hline 308 & $M$ & 0 & - & Tabasco & During day & 33,53 & 33,53 & 33,36 & - & $1,76 \mathrm{E}+03$ & 27,76 & 27,71 & 28,61 & - & $4,76 \mathrm{E}+04$ \\
\hline 309 & $M$ & 7 & - & Tabasco & During day & 29,81 & 26,4 & 29,63 & - & $2,35 \mathrm{E}+04$ & 25,9 & 21,23 & 23,91 & - & $1,24 \mathrm{E}+06$ \\
\hline 310 & $\mathrm{~F}$ & 9 & - & Tabasco & During day & 31,44 & 27,72 & 31,63 & - & $5,86 \mathrm{E}+03$ & 30,97 & 27,56 & 31,01 & - & $9,01 \mathrm{E}+03$ \\
\hline 311 & M & 6 & - & Tabasco & During day & 29,84 & 25,65 & 28,56 & - & $4,93 \mathrm{E}+04$ & 31,18 & 26,74 & 28,6 & - & $4,80 E+04$ \\
\hline 312 & $M$ & 6 & - & Tabasco & During day & NEG & NEG & NEG & - & $0,00 \mathrm{E}+00$ & 25,98 & 21,8 & 27 & - & $1,46 \mathrm{E}+05$ \\
\hline 313 & M & 7 & - & Tabasco & During day & 32,44 & 28,23 & 31,05 & - & $8,76 \mathrm{E}+03$ & 18,96 & 14,12 & 17,42 & - & $1,12 \mathrm{E}+08$ \\
\hline 314 & $M$ & 8 & - & Tabasco & During day & 36,44 & 31,5 & 34,98 & - & $5,73 \mathrm{E}+02$ & 21,61 & 18,24 & 22,49 & - & $3,33 E+06$ \\
\hline 315 & $M$ & 5 & - & Tabasco & During day & 22,01 & 17,9 & 22,3 & - & $3,80 \mathrm{E}+06$ & 31,23 & 27,53 & 29,43 & - & $2,70 \mathrm{E}+04$ \\
\hline 316 & $M$ & 8 & - & Tabasco & During day & 33,02 & 29,66 & 33,35 & - & $1,78 \mathrm{E}+03$ & 26,49 & 23,57 & 27,5 & - & $1,03 \mathrm{E}+05$ \\
\hline 317 & $M$ & 8 & - & Tabasco & During day & NEG & NEG & NEG & - & $0,00 \mathrm{E}+00$ & 25,5 & 23,16 & 26,45 & - & $2,13 \mathrm{E}+05$ \\
\hline 318 & $M$ & 8 & - & Tabasco & During day & 22,09 & 18,27 & 23,32 & - & $1,87 \mathrm{E}+06$ & 18,8 & 15,29 & 20,9 & - & $1,00 E+07$ \\
\hline 319 & M & 7 & - & Tabasco & During day & 30,95 & 31,37 & 30,35 & - & $1,42 \mathrm{E}+04$ & 19,39 & 17,32 & 19,61 & - & $2,46 \mathrm{E}+07$ \\
\hline 320 & $\mathrm{~F}$ & 9 & - & Tabasco & During day & 30,41 & 24,62 & 28,6 & - & $4,80 \mathrm{E}+04$ & 18,87 & 17,05 & 20,01 & - & $1,86 \mathrm{E}+07$ \\
\hline 321 & $\mathrm{~F}$ & 10 & - & Tabasco & During day & 28,98 & 21,77 & 28,51 & - & $5,11 \mathrm{E}+04$ & 28,33 & 21,52 & 28,25 & - & $6,12 \mathrm{E}+04$ \\
\hline 322 & $M$ & 6 & - & Tabasco & During day & 29,89 & 29,95 & 30,3 & - & $1,47 \mathrm{E}+04$ & 28,19 & 25,41 & 26,54 & - & $2,00 \mathrm{E}+05$ \\
\hline 323 & $\mathrm{~F}$ & 11 & - & Tabasco & During day & 34,1 & NEG & 34 & - & $1,13 \mathrm{E}+03$ & 24,94 & 21,87 & 22,36 & - & $3,65 \mathrm{E}+06$ \\
\hline 324 & $M$ & 10 & - & Tabasco & During day & 32 & NEG & 31,59 & - & $6,02 \mathrm{E}+03$ & 21,56 & 18,73 & 21 & - & $9,37 \mathrm{E}+06$ \\
\hline 325 & $\mathrm{~F}$ & 9 & - & Tabasco & During day & 35,13 & NEG & 33,68 & - & $1,41 \mathrm{E}+03$ & 30,71 & 28,82 & 26,76 & - & $1,72 \mathrm{E}+05$ \\
\hline 326 & $M$ & 8 & - & Tabasco & During day & 31,69 & 24,85 & 29,47 & - & $2,62 E+04$ & 30,57 & 24,08 & 30,15 & - & $1,64 \mathrm{E}+04$ \\
\hline 327 & $M$ & 4 & - & Tabasco & During day & $\mathrm{NEG}$ & $\mathrm{NEG}$ & 36,41 & - & $2,12 \mathrm{E}+02$ & 33,18 & 24,32 & 29,57 & - & $2,45 \mathrm{E}+04$ \\
\hline 328 & $M$ & NA & - & Tabasco & During day & 32,07 & 30,12 & 30,39 & - & $1,39 \mathrm{E}+04$ & 27,73 & 18,57 & 26,04 & - & $2,84 \mathrm{E}+05$ \\
\hline 329 & $M$ & 7 & - & Tabasco & During day & 24,29 & 20,94 & 23,88 & - & $1,27 \mathrm{E}+06$ & 25,05 & 21,49 & 24,41 & - & $8,79 \mathrm{E}+05$ \\
\hline 330 & $\mathrm{~F}$ & 6 & - & Tabasco & During day & 35,53 & NEG & 35,93 & - & $2,96 \mathrm{E}+02$ & 26,45 & 23,35 & 26,09 & - & $2,74 \mathrm{E}+05$ \\
\hline 331 & $\mathrm{~F}$ & NA & - & Tabasco & During day & 32,7 & 27,89 & 31,18 & - & $8,01 E+03$ & 32,34 & 28,84 & 30,85 & - & $1,01 E+04$ \\
\hline 332 & $M$ & NA & - & Tabasco & During day & 35,4 & 28,7 & 32,93 & - & $2,38 \mathrm{E}+03$ & 28,71 & 25,61 & 28,57 & - & $4,90 \mathrm{E}+04$ \\
\hline 333 & $\mathrm{~F}$ & NA & - & Tabasco & During day & 36,33 & NEG & 34,97 & - & $5,77 \mathrm{E}+02$ & 34,61 & 30,39 & 33,15 & - & $2,04 \mathrm{E}+03$ \\
\hline 334 & $M$ & NA & - & Tabasco & During day & 35,9 & NEG & 34,61 & - & $7,41 \mathrm{E}+02$ & 28,44 & 25,21 & 28,43 & - & $5,40 \mathrm{E}+04$ \\
\hline 335 & $M$ & NA & - & Tabasco & During day & 24,1 & 19,82 & 23,97 & - & $1,19 \mathrm{E}+06$ & 30,92 & 27,56 & 29,9 & - & $1,95 \mathrm{E}+04$ \\
\hline
\end{tabular}


medRxiv preprint doi: https://doi.org/10.1101/2022.02.04.22270304; this version posted February $6,2022$. The copyright holder for this preprint (which was not certified by peer review) is the author/funder, who has granted medRxiv a license to display the preprint in

It is made available under a CC-BY-NC-ND 4.0 International license .

\section{Extended data Table $1 b$}

\begin{tabular}{|c|c|c|c|c|c|c|c|c|}
\hline & \multicolumn{4}{|c|}{ Morning } & \multicolumn{4}{|c|}{ 1h after breakfast } \\
\hline ID & Orf & E & $\begin{array}{c}\text { RdRp/ } \\
\text { N genes }\end{array}$ & Viral load & Orf & $\mathbf{E}$ & $\begin{array}{c}\text { RdRp/ } \\
\text { N genes }\end{array}$ & Viral load \\
\hline 72 & - & - & 32,32 & $7,39 E+02$ & - & - & 33,02 & $4,62 E+02$ \\
\hline 75 & - & - & 29,11 & $6,39 E+03$ & - & - & 30,81 & $2,04 \mathrm{E}+03$ \\
\hline 77 & - & - & 33,18 & $4,15 E+02$ & - & - & 37,08 & $3,02 E+01$ \\
\hline 82 & - & - & 25,47 & $7,37 E+04$ & - & - & 28,22 & $1,16 \mathrm{E}+04$ \\
\hline 84 & - & - & 38,2 & $1,42 E+01$ & - & - & 36,46 & $4,57 \mathrm{E}+01$ \\
\hline 85 & - & - & 21,07 & $1,42 \mathrm{E}+06$ & - & - & 22,21 & $6,59 \mathrm{E}+05$ \\
\hline 87 & - & - & 30,74 & $2,14 \mathrm{E}+03$ & - & - & 36,62 & $4,11 E+01$ \\
\hline 88 & - & - & 34,91 & $1,30 E+02$ & - & - & 38,82 & $9,37 \mathrm{E}+00$ \\
\hline 90 & - & - & 39,98 & $4,30 \mathrm{E}+00$ & - & - & 39,47 & $6,05 E+00$ \\
\hline 91 & - & - & 34,51 & $1,70 \mathrm{E}+02$ & - & - & 33,78 & $2,77 E+02$ \\
\hline 92 & - & - & 30,73 & $2,15 E+03$ & - & - & 30,54 & $2,44 \mathrm{E}+03$ \\
\hline 99 & - & - & 32,56 & $6,29 E+02$ & - & - & 33,66 & $3,00 E+02$ \\
\hline 100 & - & - & 33,8 & $2,73 E+02$ & - & - & 31,6 & $1,20 \mathrm{E}+03$ \\
\hline 102 & - & - & 31,53 & $1,26 \mathrm{E}+03$ & - & - & 31,54 & $1,25 E+03$ \\
\hline 103 & - & - & 35,53 & $8,55 E+01$ & - & - & 29,71 & $4,27 E+03$ \\
\hline 104 & - & - & 33,27 & $3,90 E+02$ & - & - & 31,61 & $1,19 E+03$ \\
\hline 108 & - & - & 33,61 & $3,11 E+02$ & - & - & 37,44 & $2,37 \mathrm{E}+01$ \\
\hline 109 & - & - & 28,87 & $7,51 E+03$ & - & - & 30,54 & $2,44 \mathrm{E}+03$ \\
\hline 115 & - & 34,19 & - & $1,18 \mathrm{E}+03$ & - & 34,96 & - & $6,56 \mathrm{E}+02$ \\
\hline 116 & - & 32,15 & - & $5,58 \mathrm{E}+03$ & - & 34,37 & - & $1,03 E+03$ \\
\hline 118 & - & 33,2 & - & $2,49 E+03$ & - & 34,35 & - & $1,05 E+03$ \\
\hline 119 & - & 30,56 & - & $1,89 E+04$ & - & 32,07 & - & $6,03 E+03$ \\
\hline 120 & - & 20,09 & - & $5,84 \mathrm{E}+07$ & - & 21,06 & - & $2,84 \mathrm{E}+07$ \\
\hline 121 & - & 30,24 & - & $2,42 E+04$ & - & 35,36 & - & $4,82 E+02$ \\
\hline 122 & - & 28,84 & - & $7,08 \mathrm{E}+04$ & - & 32,63 & - & $3,92 E+03$ \\
\hline 123 & - & 30,78 & - & $1,60 \mathrm{E}+04$ & - & 35,37 & - & $4,78 \mathrm{E}+02$ \\
\hline 127 & - & 32,88 & - & $3,19 E+03$ & - & 36,98 & - & $1,39 E+02$ \\
\hline 130 & - & 36,04 & - & $2,82 \mathrm{E}+02$ & - & 37,31 & - & $1,08 \mathrm{E}+02$ \\
\hline 132 & - & 36,42 & - & $2,11 E+02$ & - & 35,05 & - & $6,12 \mathrm{E}+02$ \\
\hline 134 & - & 32,85 & - & $3,26 \mathrm{E}+03$ & - & 35,49 & - & $4,36 \mathrm{E}+02$ \\
\hline 136 & - & 31,9 & - & $6,76 \mathrm{E}+03$ & - & 33,63 & - & $1,82 E+03$ \\
\hline 137 & - & 33,8 & - & $1,57 E+03$ & - & 30,06 & - & $2,82 E+04$ \\
\hline 138 & - & 29,77 & - & $3,47 E+04$ & - & 31,87 & - & $7,03 E+03$ \\
\hline 139 & - & 30,32 & - & $2,27 E+04$ & - & 30,63 & - & $1,82 \mathrm{E}+04$ \\
\hline 145 & - & 31,01 & - & $1,34 \mathrm{E}+04$ & - & 33,26 & - & $2,42 E+03$ \\
\hline 153 & - & 30,88 & - & $1,48 \mathrm{E}+04$ & - & 35,97 & - & $3,02 E+02$ \\
\hline 155 & - & 36,87 & - & $1,49 E+02$ & - & 36,18 & - & $2,57 \mathrm{E}+02$ \\
\hline 158 & - & 33,19 & - & $2,51 E+03$ & - & 29,9 & - & $3,19 E+04$ \\
\hline 163 & - & 36,93 & - & $1,42 E+02$ & - & NEG & - & $0,00 E+00$ \\
\hline $336^{*}$ & - & 36,15 & - & $2,59 E+02$ & - & 33,58 & - & $1,89 E+03$ \\
\hline
\end{tabular}

*Patient was only sampled for this part of the validation. Data on age and gender is not available. 
medRxiv preprint doi: https://doi.org/10.1101/2022.02.04.22270304; this version posted February $6,2022$. The copyright holder for this preprint (which was not certified by peer review) is the author/funder, who has granted medRxiv a license to display the preprint in

perpetuity.
It is made available under a CC-BY-NC-ND 4.0 International license .

\section{Extended data Table 1c}

\begin{tabular}{|c|c|c|c|c|c|c|c|c|c|c|c|c|c|c|c|c|}
\hline & \multicolumn{4}{|c|}{ Swab-Type A } & \multicolumn{4}{|c|}{ Swab-Type B } & \multicolumn{4}{|c|}{ Swab-Type C } & \multicolumn{4}{|c|}{ Swab-Type D } \\
\hline ID & Orf & $E$ & $\begin{array}{c}\text { RdRp/ } \\
\text { N genes }\end{array}$ & $\begin{array}{l}\text { Viral } \\
\text { load }\end{array}$ & Orf & $\mathbf{E}$ & $\begin{array}{c}\text { RdRp/ } \\
\text { N genes }\end{array}$ & $\begin{array}{l}\text { Viral } \\
\text { load }\end{array}$ & Orf & $\mathbf{E}$ & $\begin{array}{c}\text { RdRp/ } \\
\text { N genes }\end{array}$ & $\begin{array}{l}\text { Viral } \\
\text { load }\end{array}$ & Orf & $\mathbf{E}$ & $\begin{array}{c}\text { RdRp/ } \\
\text { N genes }\end{array}$ & $\begin{array}{l}\text { Viral } \\
\text { load }\end{array}$ \\
\hline 102 & 30,54 & - & - & $1,92 \mathrm{E}+04$ & 31,21 & - & - & $1,15 \mathrm{E}+04$ & 32,85 & - & - & $3,26 \mathrm{E}+03$ & 31,53 & - & - & $8,98 \mathrm{E}+03$ \\
\hline 103 & 36,96 & - & - & $1,39 E+02$ & 35,61 & - & - & $3,92 E+02$ & 36,75 & - & - & $1,63 \mathrm{E}+02$ & 35,53 & - & - & $4,17 \mathrm{E}+02$ \\
\hline 105 & NEG & - & - & $0,00 \mathrm{E}+00$ & 36,13 & - & - & $2,63 \mathrm{E}+02$ & NEG & - & - & $0,00 \mathrm{E}+00$ & NEG & - & - & $0,00 \mathrm{E}+00$ \\
\hline 106 & 36,15 & - & - & $2,59 E+02$ & 37,41 & - & - & $9,85 \mathrm{E}+01$ & 38,11 & - & - & $5,75 \mathrm{E}+01$ & 37,3 & - & - & $1,07 \mathrm{E}+02$ \\
\hline 107 & NEG & - & - & $0,00 \mathrm{E}+00$ & NEG & - & - & $0,00 \mathrm{E}+00$ & NEG & - & - & $0,00 \mathrm{E}+00$ & NEG & - & - & $0,00 \mathrm{E}+00$ \\
\hline 108 & - & - & 32,25 & $8,86 \mathrm{E}+02$ & - & - & 31,29 & $1,69 \mathrm{E}+03$ & - & - & 32,98 & $5,42 \mathrm{E}+02$ & - & - & 33,61 & $3,55 \mathrm{E}+02$ \\
\hline 109 & - & - & 31,81 & $1,19 \mathrm{E}+03$ & - & - & 28,81 & $8,95 E+03$ & - & - & 29,44 & $5,86 \mathrm{E}+03$ & - & - & 28,87 & $8,60 \mathrm{E}+03$ \\
\hline 115 & 31,4 & 33,26 & - & $2,38 \mathrm{E}+03$ & 30,82 & 32,31 & - & $4,94 \mathrm{E}+03$ & 32,41 & 34,04 & - & $1,31 \mathrm{E}+03$ & 32,32 & 34,19 & - & $1,17 \mathrm{E}+03$ \\
\hline 116 & 32,24 & 33,6 & - & $1,83 E+03$ & 32,45 & 34,1 & - & $1,25 E+03$ & 34,09 & 35,47 & - & $4,37 \mathrm{E}+02$ & 32,15 & - & - & $5,58 \mathrm{E}+03$ \\
\hline 120 & 20,96 & 21,14 & - & $2,61 \mathrm{E}+07$ & 19,62 & 19,78 & - & $7,41 \mathrm{E}+07$ & 21,52 & 21,57 & - & $1,88 \mathrm{E}+07$ & 19,85 & 20,09 & - & $5,84 \mathrm{E}+07$ \\
\hline 121 & 29,5 & 30,67 & - & $1,74 \mathrm{E}+04$ & 29,01 & 29,69 & - & $3,69 \mathrm{E}+04$ & 30,31 & 31,02 & - & $1,33 \mathrm{E}+04$ & 29,54 & 30,24 & - & $2,42 E+04$ \\
\hline 130 & 33,1 & 34,01 & - & $1,34 \mathrm{E}+03$ & 33,11 & 34,06 & - & $1,29 \mathrm{E}+03$ & 32,11 & 33,31 & - & $2,29 E+03$ & 34,1 & 36,04 & - & $2,82 E+02$ \\
\hline 132 & NEG & 36,7 & - & $1,70 \mathrm{E}+02$ & NEG & NEG & - & $0,00 \mathrm{E}+00$ & NEG & NEG & - & $0,00 \mathrm{E}+00$ & NEG & 36,42 & - & $2,11 E+02$ \\
\hline 133 & 38,77 & 34,54 & - & $8,91 E+02$ & NEG & NEG & - & $0,00 \mathrm{E}+00$ & NEG & 35,41 & - & $4,57 \mathrm{E}+02$ & NEG & NEG & - & $0,00 \mathrm{E}+00$ \\
\hline 134 & 31,44 & 33,07 & - & $2,75 \mathrm{E}+03$ & 31,92 & 33,42 & - & $2,11 E+03$ & 30,42 & 32,26 & - & $5,13 \mathrm{E}+03$ & 31,71 & 32,85 & - & $3,26 \mathrm{E}+03$ \\
\hline 135 & 30,43 & 31,97 & - & $6,41 \mathrm{E}+03$ & 28,73 & 29,29 & - & $5,01 \mathrm{E}+04$ & 28,78 & 29,81 & - & $3,36 \mathrm{E}+04$ & 29,84 & 30,79 & - & $1,58 \mathrm{E}+04$ \\
\hline 137 & 33,02 & 35,33 & - & $4,86 \mathrm{E}+02$ & 33,11 & 34,44 & - & $9,62 \mathrm{E}+02$ & 32,47 & 33,97 & - & $1,38 \mathrm{E}+03$ & 32,53 & 33,8 & - & $1,57 \mathrm{E}+03$ \\
\hline 139 & 30,36 & 30,6 & - & $1,83 \mathrm{E}+04$ & 31,43 & 31,53 & - & $8,98 \mathrm{E}+03$ & 29,63 & 29,94 & - & $3,04 \mathrm{E}+04$ & 30,08 & 30,32 & - & $2,27 E+04$ \\
\hline 144 & 22,97 & 22,83 & - & $7,13 E+06$ & 25,41 & 25,34 & - & $1,04 \mathrm{E}+06$ & 25 & 25,27 & - & $1,10 \mathrm{E}+06$ & 22,4 & 22,14 & - & $1,21 E+07$ \\
\hline 145 & 30,28 & 31,31 & - & $1,06 \mathrm{E}+04$ & 30,45 & 31,32 & - & $1,06 \mathrm{E}+04$ & 30,25 & 31,3 & - & $1,07 \mathrm{E}+04$ & 30,04 & 31,01 & - & $1,34 \mathrm{E}+04$ \\
\hline 148 & NEG & 34,31 & - & $1,06 \mathrm{E}+03$ & NEG & NEG & - & $0,00 \mathrm{E}+00$ & 34,1 & 34,4 & - & $9,92 \mathrm{E}+02$ & NEG & 35 & - & $6,26 \mathrm{E}+02$ \\
\hline 153 & 30,32 & 30,8 & - & $1,57 \mathrm{E}+04$ & 30,03 & 30,14 & - & $2,61 \mathrm{E}+04$ & 29,4 & 29,55 & - & $4,11 \mathrm{E}+04$ & 30,31 & 30,88 & - & $1,48 \mathrm{E}+04$ \\
\hline
\end{tabular}


medRxiv preprint doi: https://doi.org/10.1101/2022.02.04.22270304; this version posted February $6,2022$. The copyright holder for this preprint (which was not certified by peer review) is the author/funder, who has granted medRxiv a license to display the preprint in

It is made available under a CC-BY-NC-ND 4.0 International license.

\section{Extended data Table 1d}

\begin{tabular}{|c|c|c|c|c|c|c|c|c|c|}
\hline \multicolumn{2}{|c|}{ General information } & \multicolumn{4}{|c|}{ Single-PCR } & \multicolumn{4}{|c|}{ Pool-PCR } \\
\hline ID & $\begin{array}{c}\text { Pooled } \\
\text { samples (n) }\end{array}$ & Orf & E & $\begin{array}{l}\text { RdRp/ } \\
\text { N genes }\end{array}$ & Viral load & Orf & $\mathbf{E}$ & $\begin{array}{c}\text { RdRp/ } \\
\text { N genes }\end{array}$ & Viral load \\
\hline 108 & 18 & - & - & 33,61 & $3,55 \mathrm{E}+02$ & - & - & 35,66 & $8,94 \mathrm{E}+01$ \\
\hline 109 & 18 & - & - & 28,87 & $8,60 \mathrm{E}+03$ & - & - & 29,45 & $5,82 E+03$ \\
\hline 116 & 18 & 32,15 & - & - & $5,58 \mathrm{E}+03$ & - & 35,13 & - & $5,67 \mathrm{E}+02$ \\
\hline 118 & 18 & 32,43 & 33,2 & - & $2,49 E+03$ & 32,65 & 34,62 & - & $8,38 \mathrm{E}+02$ \\
\hline 119 & 18 & 29,81 & 30,56 & - & $1,89 E+04$ & 32,02 & 32,97 & - & $2,97 \mathrm{E}+03$ \\
\hline 122 & 18 & 28,62 & 28,84 & - & $7,08 \mathrm{E}+04$ & 31,97 & 32,09 & - & $5,84 \mathrm{E}+03$ \\
\hline 123 & 18 & 29,54 & 30,78 & - & $1,60 \mathrm{E}+04$ & 30,47 & 32,31 & - & $4,94 \mathrm{E}+03$ \\
\hline 127 & 18 & 32,18 & 32,88 & - & $3,19 E+03$ & 32,4 & 34,43 & - & $9,70 \mathrm{E}+02$ \\
\hline 130 & 18 & 34,1 & 36,04 & - & $2,82 \mathrm{E}+02$ & 34,13 & 35,74 & - & $3,55 \mathrm{E}+02$ \\
\hline 132 & 18 & NEG & 36,42 & - & $2,11 E+02$ & NEG & 36,71 & - & $1,69 \mathrm{E}+02$ \\
\hline 136 & 18 & 30,61 & 31,9 & - & $6,76 \mathrm{E}+03$ & 32,2 & 33,88 & - & $1,48 \mathrm{E}+03$ \\
\hline 137 & 100 & 32,53 & 33,8 & - & $1,57 E+03$ & NEG & 37,27 & - & $1,10 \mathrm{E}+02$ \\
\hline 138 & 100 & 29,35 & 29,77 & - & $3,47 E+04$ & 31,21 & 32,06 & - & $5,98 \mathrm{E}+03$ \\
\hline 144 & 18 & 22,4 & 22,14 & - & $1,21 E+07$ & 25,01 & 24,77 & - & $1,61 E+06$ \\
\hline 145 & 50 & 30,04 & 31,01 & - & $1,34 \mathrm{E}+04$ & 31,89 & 32,83 & - & $3,31 E+03$ \\
\hline 148 & 50 & NEG & 35 & - & $6,26 \mathrm{E}+02$ & NEG & 34,45 & - & $9,55 E+02$ \\
\hline 158 & 18 & 32,28 & 33,19 & - & $2,51 E+03$ & 31,38 & 32,32 & - & $4,90 \mathrm{E}+03$ \\
\hline
\end{tabular}


medRxiv preprint doi: https://doi.org/10.1101/2022.02.04.22270304; this version posted February 6, 2022. The copyright holder for this preprint (which was not certified by peer review) is the author/funder, who has granted medRxiv a license to display the preprint in

It is made available under a CC-BY-NC-ND 4.0 International license .

\section{Extended data Table 1e}

\begin{tabular}{|c|c|c|c|c|c|c|c|c|c|c|c|c|c|c|}
\hline \multicolumn{3}{|c|}{ General information } & \multicolumn{2}{|c|}{ Sampling information } & \multicolumn{5}{|c|}{ Lolli-swab } & \multicolumn{5}{|c|}{ Np-/Op-swab } \\
\hline ID & Gender & $\begin{array}{l}\text { Days after } \\
\text { symptom } \\
\text { onset }\end{array}$ & $\begin{array}{c}\text { Side of } \\
\text { sampling }\end{array}$ & $\begin{array}{l}\text { Sampling } \\
\text { time }\end{array}$ & Orf & E & $\mathbf{N}$ & $\begin{array}{c}\text { RdRp/ } \\
\text { N genes }\end{array}$ & $\begin{array}{l}\text { Viral } \\
\text { load }\end{array}$ & Orf & $\mathbf{E}$ & $\mathbf{N}$ & $\begin{array}{c}\text { RdRp/ } \\
\text { N genes }\end{array}$ & $\begin{array}{l}\text { Viral } \\
\text { load }\end{array}$ \\
\hline 1 & Female & 7 & Cologne & During day & - & - & - & NEG & $0,00 \mathrm{E}+00$ & - & - & - & NEG & $0,00 \mathrm{E}+00$ \\
\hline 2 & Female & 6 & Cologne & During day & - & - & - & NEG & $0,00 \mathrm{E}+00$ & - & - & - & NEG & $0,00 \mathrm{E}+00$ \\
\hline 5 & Female & - & Cologne & During day & - & - & - & NEG & $0,00 \mathrm{E}+00$ & - & - & - & NEG & $0,00 \mathrm{E}+00$ \\
\hline 14 & Male & 9 & Cologne & During day & - & - & - & NEG & $0,00 \mathrm{E}+00$ & - & - & - & NEG & $0,00 \mathrm{E}+00$ \\
\hline 30 & Female & - & Cologne & Morning & - & - & - & NEG & $0,00 \mathrm{E}+00$ & - & - & - & NEG & $0,00 \mathrm{E}+00$ \\
\hline 38 & Female & 5 & Cologne & Morning & - & - & - & NEG & $0,00 \mathrm{E}+00$ & - & - & - & NEG & $0,00 \mathrm{E}+00$ \\
\hline 41 & Female & 4 & Cologne & Morning & - & - & - & NEG & $0,00 \mathrm{E}+00$ & - & - & - & NEG & $0,00 \mathrm{E}+00$ \\
\hline 44 & Male & - & Cologne & Morning & - & - & - & NEG & $0,00 \mathrm{E}+00$ & - & - & - & NEG & $0,00 \mathrm{E}+00$ \\
\hline 50 & Male & 9 & Cologne & Morning & - & - & - & NEG & $0,00 \mathrm{E}+00$ & - & - & - & NEG & $0,00 \mathrm{E}+00$ \\
\hline 58 & Male & - & Cologne & Morning & - & - & - & NEG & $0,00 \mathrm{E}+00$ & - & - & - & NEG & $0,00 \mathrm{E}+00$ \\
\hline 59 & Male & - & Cologne & Morning & - & - & - & NEG & $0,00 \mathrm{E}+00$ & - & - & - & NEG & $0,00 \mathrm{E}+00$ \\
\hline 60 & Male & 0 & Cologne & Morning & - & - & - & NEG & $0,00 \mathrm{E}+00$ & - & - & - & NEG & $0,00 \mathrm{E}+00$ \\
\hline 61 & Male & 0 & Cologne & Morning & - & - & - & NEG & $0,00 \mathrm{E}+00$ & - & - & - & NEG & $0,00 \mathrm{E}+00$ \\
\hline 63 & Female & - & Cologne & Morning & - & - & - & NEG & $0,00 \mathrm{E}+00$ & - & - & - & NEG & $0,00 \mathrm{E}+00$ \\
\hline 64 & Female & - & Cologne & Morning & - & - & - & NEG & $0,00 \mathrm{E}+00$ & - & - & - & NEG & $0,00 \mathrm{E}+00$ \\
\hline 67 & Female & - & Cologne & Morning & - & - & - & NEG & $0,00 \mathrm{E}+00$ & - & - & - & NEG & $0,00 \mathrm{E}+00$ \\
\hline 73 & Female & 3 & Cologne & Morning & - & - & - & NEG & $0,00 \mathrm{E}+00$ & - & - & - & NEG & $0,00 \mathrm{E}+00$ \\
\hline 74 & Female & - & Cologne & During day & - & - & - & NEG & $0,00 \mathrm{E}+00$ & - & - & - & NEG & $0,00 \mathrm{E}+00$ \\
\hline 76 & Male & 3 & Cologne & Morning & - & - & - & NEG & $0,00 \mathrm{E}+00$ & - & - & - & NEG & $0,00 \mathrm{E}+00$ \\
\hline 78 & Female & - & Cologne & Morning & - & - & - & NEG & $0,00 \mathrm{E}+00$ & - & - & - & NEG & $0,00 \mathrm{E}+00$ \\
\hline 79 & Male & - & Cologne & Morning & - & - & - & NEG & $0,00 \mathrm{E}+00$ & - & - & - & NEG & $0,00 \mathrm{E}+00$ \\
\hline 80 & Male & - & Cologne & Morning & - & - & - & NEG & $0,00 \mathrm{E}+00$ & - & - & - & NEG & $0,00 \mathrm{E}+00$ \\
\hline 81 & Female & - & Cologne & Morning & - & - & - & NEG & $0,00 \mathrm{E}+00$ & - & - & - & NEG & $0,00 E+00$ \\
\hline 83 & Female & - & Cologne & Morning & - & - & - & NEG & $0,00 E+00$ & - & - & - & NEG & $0,00 E+00$ \\
\hline 86 & Male & - & Cologne & Morning & - & - & - & NEG & $0,00 \mathrm{E}+00$ & - & - & - & NEG & $0,00 \mathrm{E}+00$ \\
\hline 89 & Female & - & Cologne & Morning & - & - & - & NEG & $0,00 \mathrm{E}+00$ & - & - & - & NEG & $0,00 \mathrm{E}+00$ \\
\hline 90 & Female & 11 & Cologne & During day & NEG & - & - & - & $0,00 \mathrm{E}+00$ & NEG & - & - & - & $0,00 \mathrm{E}+00$ \\
\hline 96 & Female & - & Cologne & Morning & - & - & - & NEG & $0,00 \mathrm{E}+00$ & - & - & - & NEG & $0,00 \mathrm{E}+00$ \\
\hline 101 & Female & - & Cologne & Morning & NEG & - & - & - & $0,00 \mathrm{E}+00$ & NEG & - & - & - & $0,00 \mathrm{E}+00$ \\
\hline 111 & Male & 1 & Cologne & Morning & NEG & - & - & - & $0,00 \mathrm{E}+00$ & NEG & - & - & - & $0,00 \mathrm{E}+00$ \\
\hline 112 & Female & 2 & Cologne & Morning & NEG & - & - & - & $0,00 \mathrm{E}+00$ & NEG & - & - & - & $0,00 \mathrm{E}+00$ \\
\hline 113 & Female & - & Cologne & Morning & NEG & - & - & - & $0,00 \mathrm{E}+00$ & NEG & - & - & - & $0,00 \mathrm{E}+00$ \\
\hline 114 & Male & 6 & Cologne & Morning & NEG & - & - & - & $0,00 \mathrm{E}+00$ & NEG & - & - & - & $0,00 \mathrm{E}+00$ \\
\hline 117 & Male & - & Cologne & Morning & NEG & - & - & - & $0,00 \mathrm{E}+00$ & NEG & - & - & - & $0,00 \mathrm{E}+00$ \\
\hline 124 & Female & - & Cologne & Morning & NEG & - & - & - & $0,00 \mathrm{E}+00$ & NEG & - & - & - & $0,00 \mathrm{E}+00$ \\
\hline 125 & Male & - & Cologne & Morning & NEG & - & - & - & $0,00 \mathrm{E}+00$ & NEG & - & - & - & $0,00 \mathrm{E}+00$ \\
\hline 126 & Female & - & Cologne & Morning & NEG & - & - & - & $0,00 \mathrm{E}+00$ & NEG & - & - & - & $0,00 \mathrm{E}+00$ \\
\hline 128 & Female & 0 & Cologne & Morning & NEG & NEG & - & - & $0,00 \mathrm{E}+00$ & NEG & NEG & - & - & $0,00 \mathrm{E}+00$ \\
\hline 129 & Female & 1 & Cologne & Morning & NEG & NEG & - & - & $0,00 \mathrm{E}+00$ & NEG & NEG & - & - & $0,00 E+00$ \\
\hline 131 & Male & - & Cologne & Morning & NEG & NEG & - & - & $0,00 \mathrm{E}+00$ & NEG & NEG & - & - & $0,00 E+00$ \\
\hline 140 & Female & 2 & Cologne & Morning & NEG & NEG & - & - & $0,00 \mathrm{E}+00$ & NEG & NEG & - & - & $0,00 \mathrm{E}+00$ \\
\hline 146 & Female & 6 & Cologne & Morning & NEG & NEG & - & - & $0,00 \mathrm{E}+00$ & NEG & NEG & - & - & $0,00 \mathrm{E}+00$ \\
\hline 147 & Female & - & Cologne & Morning & NEG & NEG & - & - & $0,00 \mathrm{E}+00$ & NEG & NEG & - & - & $0,00 \mathrm{E}+00$ \\
\hline 149 & Male & - & Cologne & Morning & NEG & NEG & - & - & $0,00 \mathrm{E}+00$ & NEG & NEG & - & - & $0,00 \mathrm{E}+00$ \\
\hline 152 & Male & - & Cologne & Morning & NEG & NEG & - & - & $0,00 \mathrm{E}+00$ & NEG & NEG & - & - & $0,00 \mathrm{E}+00$ \\
\hline 154 & Male & - & Cologne & Morning & NEG & NEG & - & - & $0,00 \mathrm{E}+00$ & NEG & NEG & - & - & $0,00 \mathrm{E}+00$ \\
\hline 156 & Female & - & Cologne & Morning & NEG & NEG & - & - & $0,00 \mathrm{E}+00$ & NEG & NEG & - & - & $0,00 \mathrm{E}+00$ \\
\hline 179 & Male & - & Cologne & Morning & - & - & - & NEG & $0,00 \mathrm{E}+00$ & - & - & - & NEG & $0,00 \mathrm{E}+00$ \\
\hline 179 & Male & - & Cologne & During day & - & - & - & NEG & $0,00 \mathrm{E}+00$ & - & - & - & NEG & $0,00 \mathrm{E}+00$ \\
\hline 180 & Male & - & Cologne & Morning & - & - & - & NEG & $0,00 \mathrm{E}+00$ & - & - & - & NEG & $0,00 \mathrm{E}+00$ \\
\hline 180 & Male & - & Cologne & During day & - & - & - & NEG & $0,00 \mathrm{E}+00$ & - & - & - & NEG & $0,00 \mathrm{E}+00$ \\
\hline 183 & Male & - & Cologne & Morning & - & - & - & NEG & $0,00 \mathrm{E}+00$ & - & - & - & NEG & $0,00 \mathrm{E}+00$ \\
\hline 183 & Male & - & Cologne & During day & - & - & - & NEG & $0,00 \mathrm{E}+00$ & - & - & - & NEG & $0,00 \mathrm{E}+00$ \\
\hline 191 & Male & - & Cologne & Morning & - & NEG & - & - & $0,00 \mathrm{E}+00$ & - & NEG & - & - & $0,00 \mathrm{E}+00$ \\
\hline 192 & Female & - & Cologne & Morning & - & NEG & - & - & $0,00 \mathrm{E}+00$ & - & NEG & - & - & $0,00 \mathrm{E}+00$ \\
\hline
\end{tabular}


medRxiv preprint doi: https://doi.org/10.1101/2022.02.04.22270304; this version posted February 6, 2022. The copyright holder for this preprint (which was not certified by peer review) is the author/funder, who has granted medRxiv a license to display the preprint in

It is made available under a CC-BY-NC-ND 4.0 International license .

\section{Extended data Table 2}

\begin{tabular}{|c|c|c|c|}
\multicolumn{1}{c|}{ Parameter } & Description & Value & Reference \\
\hline \multirow{2}{*}{$\tau_{\text {pre }}$} & $\begin{array}{c}\text { Time between infection } \\
\text { and infectiousness }\end{array}$ & 3 days & 42 \\
\hline$\tau_{\text {inf }}$ & Duration of infectiousness & 6 days & 43 \\
\hline \multirow{2}{*}{ R0 } & \multirow{2}{*}{ Basic reproduction number } & 2,5 & 44 \\
\cline { 3 - 4 } & & 4,5 & 5,45 \\
\hline$p_{i n}$ & & $0,10 \%$ & 39 \\
\hline \multirow{2}{*}{$p_{P C R}$} & $\begin{array}{c}\text { False-negative rate } \\
\text { of RT-qPCR }\end{array}$ & $0,01 \%$ & Assumption \\
\hline$g$ & Exponential growth rate of viral load & $1 /(4,5$ days $)$ & 49 \\
\hline
\end{tabular}


medRxiv preprint doi: https://doi.org/10.1101/2022.02.04.22270304; this version posted February 6, 2022. The copyright holder for this preprint (which was not certified by peer review) is the author/funder, who has granted medRxiv a license to display the preprint in

It is made available under a CC-BY-NC-ND 4.0 International license .

\section{Extended data Table 3}

\begin{tabular}{|c|c|c|c|c|c|c|}
\hline \multirow[t]{2}{*}{ District } & \multicolumn{3}{|c|}{ Schools (n) } & \multicolumn{3}{|c|}{ Pupils (n) } \\
\hline & $\begin{array}{l}\text { Elementary } \\
\text { schools }\end{array}$ & $\begin{array}{l}\text { Schools for } \\
\text { special needs }\end{array}$ & $\begin{array}{c}\text { Other } \\
\text { schools }\end{array}$ & $\begin{array}{c}\text { Elementary } \\
\text { schools }\end{array}$ & $\begin{array}{l}\text { Schools for } \\
\text { special needs }\end{array}$ & $\begin{array}{c}\text { Other } \\
\text { schools }\end{array}$ \\
\hline Aachen & 99 & 22 & 0 & 18629 & 3358 & 0 \\
\hline Bielefeld & 51 & 13 & 0 & 12475 & 2292 & 0 \\
\hline Bochum & 52 & 14 & 0 & 11584 & 3310 & 0 \\
\hline Bonn & 55 & 8 & 1 & 12230 & 1352 & 416 \\
\hline Borken & 74 & 11 & 0 & 14483 & 1598 & 0 \\
\hline Bottrop & 20 & 3 & 0 & 4010 & 224 & 0 \\
\hline Coesfeld & 40 & 5 & 0 & 8182 & 860 & 0 \\
\hline Dortmund & 91 & 19 & 1 & 21496 & 2868 & 738 \\
\hline Duisburg & 77 & 15 & 0 & 18417 & 2607 & 0 \\
\hline Düren & 55 & 7 & 1 & 9272 & 1385 & 481 \\
\hline Düsseldorf & 94 & 17 & 0 & 21777 & 3178 & 0 \\
\hline Ennepe-Ruhr-Kreis & 56 & 8 & 1 & 10709 & 1340 & 375 \\
\hline Essen & 87 & 22 & 0 & 20396 & 3865 & 0 \\
\hline Euskirchen & 39 & 9 & 0 & 6729 & 1206 & 0 \\
\hline Gelsenkirchen & 41 & 10 & 0 & 10411 & 1953 & 0 \\
\hline Gütersloh & 69 & 15 & 0 & 13840 & 1809 & 0 \\
\hline Hagen & 33 & 6 & 0 & 7186 & 1160 & 0 \\
\hline Hamm & 28 & 6 & 1 & 6682 & 797 & 344 \\
\hline Heinsberg & 55 & 7 & 0 & 9085 & 974 & 0 \\
\hline Herford & 51 & 6 & 0 & 9230 & 1046 & 0 \\
\hline Herne & 21 & 6 & 1 & 5593 & 656 & 1065 \\
\hline Hochsauerlandkreis & 64 & 12 & 0 & 8756 & 1038 & 0 \\
\hline Höxter & 25 & 6 & 0 & 4841 & 621 & 0 \\
\hline Kleve & 58 & 11 & 0 & 11105 & 1513 & 0 \\
\hline Krefeld & 34 & 8 & 1 & 7955 & 1459 & 487 \\
\hline Köln & 159 & 28 & 0 & 38152 & 4844 & 0 \\
\hline Leverkusen & 25 & 4 & 0 & 6457 & 399 & 0 \\
\hline Lippe & 66 & 13 & 0 & 13229 & 1850 & 0 \\
\hline Mettmann & 83 & 14 & 0 & 17856 & 1841 & 0 \\
\hline Minden-Lübbecke & 64 & 14 & 2 & 11554 & 1477 & 998 \\
\hline Märkischer Kreis & 70 & 11 & 1 & 14360 & 1822 & 518 \\
\hline Mönchengladbach & 43 & 12 & 0 & 9408 & 1680 & 0 \\
\hline Mülheim an der Ruhr & 24 & 4 & 0 & 6100 & 1067 & 0 \\
\hline Münster & 47 & 8 & 2 & 9956 & 1798 & 516 \\
\hline Oberbergischer Kreis & 51 & 11 & 0 & 10204 & 1783 & 0 \\
\hline Oberhausen & 31 & 5 & 0 & 7202 & 715 & 0 \\
\hline Olpe & 35 & 7 & 0 & 4885 & 1022 & 0 \\
\hline Paderborn & 64 & 10 & 0 & 11768 & 1834 & 0 \\
\hline Recklinghausen & 99 & 20 & 0 & 21906 & 3170 & 0 \\
\hline Remscheid & 21 & 6 & 0 & 3976 & 509 & 0 \\
\hline Rhein-Erft-Kreis & 78 & 15 & 0 & 17877 & 2135 & 0 \\
\hline Rhein-Kreis Neuss & 79 & 9 & 0 & 17238 & 1400 & 0 \\
\hline Rhein-Sieg-Kreis & 102 & 24 & 0 & 22715 & 3137 & 0 \\
\hline Rheinisch-Bergischer Kreis & 56 & 8 & 0 & 10376 & 1165 & 0 \\
\hline Siegen-Wittgenstein & 62 & 8 & 1 & 9868 & 875 & 333 \\
\hline Soest & 58 & 13 & 1 & 10648 & 1862 & 280 \\
\hline Solingen & 27 & 6 & 0 & 5608 & 622 & 0 \\
\hline Steinfurt & 89 & 17 & 1 & 16816 & 2154 & 103 \\
\hline Unna & 63 & 8 & 0 & 13860 & 1211 & 0 \\
\hline Viersen & 48 & 8 & 1 & 10105 & 966 & 336 \\
\hline Warendorf & 58 & 5 & 0 & 10431 & 768 & 0 \\
\hline Wesel & 77 & 12 & 0 & 15722 & 2525 & 0 \\
\hline Wuppertal & 57 & 11 & 2 & 13085 & 1558 & 688 \\
\hline Total & $\overline{3105}$ & $\overline{577}$ & $\overline{\overline{18}}$ & $\overline{646435}$ & 88658 & $\overline{\overline{77678}}$ \\
\hline
\end{tabular}


medRxiv preprint doi: https://doi.org/10.1101/2022.02.04.22270304; this version posted February $6,2022$. The copyright holder for this

preprint (which was not certified by peer review) is the author/funder, who has granted medRxiv a license to display the preprint in perpetuity.

It is made available under a CC-BY-NC-ND 4.0 International license.

\section{Extended data Table 4}

\begin{tabular}{|c|c|c|c|c|c|c|c|c|c|c|}
\hline $\begin{array}{l}\text { Calendar } \\
\text { week }\end{array}$ & $\begin{array}{l}\text { Lab } \\
\text { ID }\end{array}$ & $\begin{array}{l}\text { Pool- } \\
\text { PCRs } \\
\text { (n) }\end{array}$ & $\begin{array}{c}\text { Positive } \\
\text { Pool-PCRs } \\
\text { (n) }\end{array}$ & $\begin{array}{c}\text { Positive } \\
\text { Pool-PCRs } \\
\text { (\%) }\end{array}$ & $\begin{array}{c}\text { Pool-PCR } \\
\text { results } \\
\text { before } \\
\text { 6:00 a.m. } \\
(\%)\end{array}$ & $\begin{array}{c}\text { Single- } \\
\text { PCRs } \\
\text { (n) }\end{array}$ & $\begin{array}{c}\text { Positive } \\
\text { Single-PCRs } \\
\text { (n) }\end{array}$ & $\begin{array}{c}\text { Single- } \\
\text { PCRs } \\
\text { results } \\
\text { before } \\
\text { 6:00 a.m. } \\
(\%)\end{array}$ & $\begin{array}{l}\text { Schools } \\
\text { (n) }\end{array}$ & $\begin{array}{c}\text { Pupils } \\
\text { (estimated } n \text { ) }\end{array}$ \\
\hline \multirow{13}{*}{19} & Total & 62981 & 287 & 0,46 & 77,8 & 2649 & 136 & 67,76 & 3215 & 452521 \\
\hline & 1 & 10917 & 42 & 0,38 & 81,6 & 0 & 0 & - & 526 & 79480 \\
\hline & 2 & 9708 & 46 & 0,47 & 100 & 372 & 20 & 95,7 & 528 & 68795 \\
\hline & 3 & 10085 & 25 & 0,25 & 37,01 & 701 & 43 & 39,37 & 448 & 74812 \\
\hline & 4 & 7450 & 19 & 0,26 & 99,64 & 242 & 13 & 100 & 444 & 52762 \\
\hline & 5 & 5743 & 46 & 0,80 & 97,41 & 147 & 12 & 60,54 & 336 & 42886 \\
\hline & 6 & 5384 & 12 & 0,22 & 27,08 & 120 & 7 & 93,33 & 252 & 36165 \\
\hline & 7 & 5684 & 18 & 0,32 & 100 & 255 & 11 & 19,22 & 267 & 41710 \\
\hline & 8 & 1669 & 10 & 0,60 & 99,34 & 104 & 6 & 100 & 99 & 11716 \\
\hline & 9 & 724 & 4 & 0,55 & 87,15 & 0 & 0 & - & 26 & 5162 \\
\hline & 10 & 2424 & 43 & 1,77 & 100 & 492 & 14 & 100 & 92 & 17534 \\
\hline & 11 & 1413 & 15 & 1,06 & 0 & 141 & 5 & 0 & 116 & 9898 \\
\hline & 12 & 1780 & 7 & 0,39 & 100 & 75 & 5 & 100 & 81 & 11600 \\
\hline \multirow{13}{*}{20} & Total & 114134 & 337 & 0,30 & 90,86 & 3137 & 192 & 90,88 & 3608 & 615306 \\
\hline & 1 & 20576 & 37 & 0,18 & 78 & 0 & 0 & - & 570 & 112803 \\
\hline & 2 & 16273 & 55 & 0,34 & 100 & 558 & 35 & 98,75 & 549 & 87052 \\
\hline & 3 & 15381 & 39 & 0,25 & 99,92 & 758 & 36 & 98,94 & 477 & 84443 \\
\hline & 4 & 15426 & 45 & 0,29 & 98,72 & 505 & 42 & 99,6 & 478 & 82766 \\
\hline & 5 & 12804 & 56 & 0,44 & 97,31 & 275 & 16 & 98,55 & 442 & 70424 \\
\hline & 6 & 8098 & 12 & 0,15 & 81,29 & 164 & 10 & 92,07 & 258 & 41084 \\
\hline & 7 & 9302 & 21 & 0,23 & 100 & 283 & 16 & 60,07 & 304 & 50980 \\
\hline & 8 & 3289 & 14 & 0,43 & 99,94 & 158 & 11 & 93,67 & 101 & 17492 \\
\hline & 9 & 4238 & 23 & 0,54 & 75,27 & 0 & 0 & - & 127 & 22612 \\
\hline & 10 & 3164 & 20 & 0,63 & 99,97 & 252 & 14 & 100 & 92 & 17292 \\
\hline & 11 & 2779 & 8 & 0,29 & 0 & 99 & 7 & 0 & 128 & 14342 \\
\hline & 12 & 2804 & 7 & 0,25 & 100 & 85 & 5 & 64,71 & 83 & 14016 \\
\hline \multirow{13}{*}{21} & Total & 64222 & 178 & 0,28 & 95,82 & 1930 & 109 & 94,61 & 3614 & 693232 \\
\hline & 1 & 10126 & 41 & 0,40 & 99,48 & 206 & 9 & 100 & 566 & 110803 \\
\hline & 2 & 9757 & 34 & 0,35 & 99,99 & 348 & 24 & 100 & 555 & 105325 \\
\hline & 3 & 8797 & 35 & 0,40 & 97,61 & 614 & 36 & 95,44 & 474 & 96959 \\
\hline & 4 & 8994 & 8 & 0,09 & 99,8 & 174 & 5 & 99,43 & 476 & 97218 \\
\hline & 5 & 8306 & 14 & 0,17 & 98,45 & 155 & 8 & 96,13 & 453 & 90659 \\
\hline & 6 & 4332 & 1 & 0,02 & 100 & 33 & 1 & 93,94 & 257 & 44300 \\
\hline & 7 & 4916 & 9 & 0,18 & 99,96 & 108 & 7 & 93,52 & 306 & 53398 \\
\hline & 8 & 1698 & 9 & 0,53 & 100 & 95 & 5 & 100 & 101 & 17980 \\
\hline & 9 & 2504 & 9 & 0,36 & 75,48 & 0 & 0 & - & 127 & 26380 \\
\hline & 10 & 1616 & 7 & 0,43 & 99,75 & 76 & 3 & 100 & 92 & 17607 \\
\hline & 11 & 1653 & 5 & 0,30 & 0 & 50 & 4 & 0 & 125 & 17227 \\
\hline & 12 & 1523 & 6 & 0,39 & 100 & 71 & 7 & 85,92 & 83 & 15374 \\
\hline \multirow{13}{*}{22} & Total & 77545 & 204 & 0,26 & 95,66 & 4032 & 116 & 86,9 & 3655 & 672405 \\
\hline & 1 & 13527 & 58 & 0,43 & 85,72 & 1149 & 18 & 65,36 & 572 & 116475 \\
\hline & 2 & 12048 & 38 & 0,32 & 96,57 & 675 & 25 & 99,85 & 567 & 104733 \\
\hline & 3 & 10838 & 10 & 0,09 & 99,67 & 436 & 10 & 90,6 & 479 & 91553 \\
\hline & 4 & 9487 & 9 & 0,09 & 99,91 & 240 & 7 & 99,58 & 477 & 82411 \\
\hline & 5 & 10432 & 46 & 0,44 & 98,95 & 816 & 30 & 91,42 & 455 & 92286 \\
\hline & 6 & 5043 & 7 & 0,14 & 100 & 129 & 6 & 96,12 & 259 & 43881 \\
\hline & 7 & 5741 & 7 & 0,12 & 99,98 & 125 & 6 & 91,2 & 310 & 50381 \\
\hline & 8 & 1990 & 7 & 0,35 & 100 & 135 & 3 & 100 & 101 & 17745 \\
\hline & 9 & 2734 & 8 & 0,29 & 89,65 & 0 & 0 & - & 133 & 24012 \\
\hline & 10 & 1909 & 2 & 0,10 & 100 & 86 & 2 & 100 & 92 & 16944 \\
\hline & 11 & 1906 & 6 & 0,31 & 69,41 & 133 & 2 & 99,25 & 129 & 16765 \\
\hline & 12 & 1890 & 6 & 0,32 & 100 & 108 & 7 & 100 & 83 & 15219 \\
\hline \multirow{13}{*}{23} & Total & 80366 & 142 & 0,18 & 99,58 & 3140 & 87 & 98,76 & 3655 & 695707 \\
\hline & 1 & 13715 & 36 & 0,26 & 99,23 & 657 & 10 & 100 & 575 & 117677 \\
\hline & 2 & 12409 & 33 & 0,27 & 99,96 & 822 & 25 & 99,76 & 562 & 107798 \\
\hline & 3 & 11082 & 5 & 0,05 & 99,59 & 91 & 2 & 89,01 & 479 & 93465 \\
\hline & 4 & 10476 & 14 & 0,13 & 99,9 & 359 & 6 & 100 & 478 & 90643 \\
\hline & 5 & 10851 & 22 & 0,20 & 99,66 & 437 & 21 & 97,48 & 457 & 95545 \\
\hline & 6 & 5132 & 3 & 0,06 & 100 & 171 & 2 & 99,42 & 259 & 44551 \\
\hline & 7 & 5892 & 7 & 0,12 & 99,98 & 147 & 6 & 93,2 & 308 & 51867 \\
\hline & 8 & 2023 & 9 & 0,44 & 100 & 182 & 8 & 100 & 102 & 18076 \\
\hline & 9 & 2999 & 3 & 0,10 & 95,87 & 0 & 0 & - & 132 & 26545 \\
\hline & 10 & 1924 & 3 & 0,16 & 99,74 & 126 & 1 & 98,41 & 92 & 17037 \\
\hline & 11 & 1962 & 3 & 0,15 & 100 & 64 & 3 & 100 & 129 & 17203 \\
\hline & 12 & 1901 & 4 & 0,21 & 99,89 & 84 & 3 & 96,43 & 83 & 15300 \\
\hline
\end{tabular}


medRxiv preprint doi: https://doi.org/10.1101/2022.02.04.22270304; this version posted February $6,2022$. The copyright holder for this

preprint (which was not certified by peer review) is the author/funder, who has granted medRxiv a license to display the preprint in perpetuity.

It is made available under a CC-BY-NC-ND 4.0 International license.

\section{Extended data Table 4}

\begin{tabular}{|c|c|c|c|c|c|c|c|c|c|c|}
\hline $\begin{array}{c}\text { Calendar } \\
\text { week }\end{array}$ & $\begin{array}{l}\text { Lab } \\
\text { ID }\end{array}$ & $\begin{array}{l}\text { Pool- } \\
\text { PCRs } \\
\text { (n) }\end{array}$ & $\begin{array}{c}\text { Positive } \\
\text { Pool-PCRs } \\
\text { (n) }\end{array}$ & $\begin{array}{c}\text { Positive } \\
\text { Pool-PCRs } \\
\text { (\%) }\end{array}$ & $\begin{array}{c}\text { Pool-PCR } \\
\text { results } \\
\text { before } \\
\text { 6:00 a.m. } \\
\text { (\%) }\end{array}$ & $\begin{array}{l}\text { Single- } \\
\text { PCRs } \\
\text { (n) }\end{array}$ & $\begin{array}{c}\text { Positive } \\
\text { Single-PCRs } \\
\text { (n) }\end{array}$ & $\begin{array}{c}\text { Single- } \\
\text { PCRs } \\
\text { results } \\
\text { before } \\
\text { 6:00 a.m. } \\
(\%)\end{array}$ & $\begin{array}{l}\text { Schools } \\
\text { (n) }\end{array}$ & $\begin{array}{c}\text { Pupils } \\
\text { (estimated } n \text { ) }\end{array}$ \\
\hline \multirow{13}{*}{24} & Total & 80074 & 74 & 0,09 & 99,28 & 1640 & 42 & 98,6 & 3644 & 693093 \\
\hline & 1 & 13606 & $\overline{11}$ & 0,08 & 99,82 & 232 & 6 & 99,57 & 570 & 116760 \\
\hline & 2 & 12338 & 18 & 0,15 & 99,99 & 406 & 15 & 100 & 559 & 107015 \\
\hline & 3 & 10885 & 4 & 0,04 & 99,97 & 85 & 3 & 77,65 & 479 & 91958 \\
\hline & 4 & 10743 & 3 & 0,03 & 99,99 & 149 & 1 & 100 & 478 & 92778 \\
\hline & 5 & 10732 & 17 & 0,16 & 97,32 & 305 & 2 & 100 & 456 & 94511 \\
\hline & 6 & 5112 & 2 & 0,04 & 100 & 77 & 1 & 98,7 & 259 & 44382 \\
\hline & 7 & 5842 & 4 & 0,07 & 100 & 43 & 5 & 95,35 & 306 & 51521 \\
\hline & 8 & 2042 & 4 & 0,20 & 99,95 & 102 & 3 & 100 & 102 & 18263 \\
\hline & 9 & 3019 & 4 & 0,13 & 91,55 & 0 & 0 & - & 131 & 26693 \\
\hline & 10 & 1915 & 1 & 0,05 & 99,95 & 105 & 0 & 100 & 92 & 16925 \\
\hline & 11 & 1962 & 3 & 0,15 & 100 & 63 & 3 & 100 & 129 & 17201 \\
\hline & 12 & 1878 & 3 & 0,16 & 100 & 73 & 3 & 100 & 83 & 15087 \\
\hline \multirow{13}{*}{25} & Total & 79799 & 55 & 0,07 & 97,94 & 1326 & 24 & 98,72 & 3646 & 691641 \\
\hline & 1 & 13556 & 17 & 0,13 & 90,11 & 333 & 2 & 100 & 570 & 116482 \\
\hline & 2 & 12269 & 10 & 0,08 & 100 & 288 & 9 & 98,96 & 564 & 106545 \\
\hline & 3 & 10810 & 3 & 0,03 & 99,89 & 78 & 2 & 100 & 478 & 91272 \\
\hline & 4 & 10678 & 3 & 0,03 & 99,94 & 54 & 1 & 100 & 477 & 92372 \\
\hline & 5 & 10759 & 8 & 0,07 & 99,69 & 147 & 1 & 100 & 455 & 94933 \\
\hline & 6 & 5089 & 4 & 0,08 & 100 & 66 & 3 & 98,48 & 259 & 44310 \\
\hline & 7 & 5877 & 3 & 0,05 & 100 & 73 & 2 & 82,19 & 306 & 51923 \\
\hline & 8 & 2024 & 2 & 0,10 & 100 & 45 & 0 & 100 & 102 & 18120 \\
\hline & 9 & 3010 & 0 & 0,00 & 91,79 & 0 & 0 & - & 131 & 26614 \\
\hline & 10 & 1901 & 1 & 0,05 & 99,95 & 93 & 2 & 100 & 92 & 16843 \\
\hline & 11 & 1956 & 3 & 0,15 & 100 & 127 & 1 & 100 & 129 & 17169 \\
\hline & 12 & 1870 & 1 & 0,05 & 100 & 22 & 1 & 100 & 83 & 15058 \\
\hline \multirow{13}{*}{26} & Total & 72318 & 39 & 0,05 & 99,58 & 867 & 16 & 97,23 & 3643 & 627656 \\
\hline & 1 & 6760 & 3 & 0,04 & 98,54 & 1 & 0 & 100 & 569 & 58108 \\
\hline & 2 & 12208 & 7 & 0,06 & 100 & 151 & 6 & 99,34 & 562 & 106223 \\
\hline & 3 & 10755 & 3 & 0,03 & 99,94 & 80 & 0 & 97,5 & 478 & 90989 \\
\hline & 4 & 10608 & 5 & 0,05 & 100 & 122 & 4 & 100 & 477 & 91780 \\
\hline & 5 & 10524 & 8 & 0,08 & 99,98 & 223 & 2 & 91,48 & 455 & 92835 \\
\hline & 6 & 4956 & 4 & 0,08 & 100 & 112 & 2 & 98,21 & 259 & 43082 \\
\hline & 7 & 5878 & 1 & 0,02 & 100 & 18 & 1 & 100 & 306 & 51917 \\
\hline & 8 & 1989 & 3 & 0,15 & 100 & 67 & 0 & 100 & 102 & 17818 \\
\hline & 9 & 2957 & 3 & 0,10 & 93,44 & 1 & 0 & 100 & 131 & 26231 \\
\hline & 10 & 1889 & 0 & 0,00 & 100 & 71 & 0 & 100 & 92 & 16698 \\
\hline & 11 & 1932 & 1 & 0,05 & 100 & 21 & 1 & 100 & 129 & 16978 \\
\hline & 12 & 1862 & 1 & 0,05 & 99,95 & 0 & 0 & - & 83 & 14996 \\
\hline \multirow{12}{*}{33} & Total & 32868 & 859 & 2,61 & 99,42 & 16423 & 641 & 91,13 & 3605 & 563281 \\
\hline & 1 & 5446 & 100 & 1,84 & 97,61 & 1545 & 64 & 93,92 & 551 & 92362 \\
\hline & 2 & 4954 & 179 & 3,61 & 99,19 & 3300 & 128 & 99,21 & 537 & 85665 \\
\hline & 3 & 4484 & 138 & 3,08 & 100 & 2570 & 83 & 85,33 & 476 & 74764 \\
\hline & 4 & 4524 & 69 & 1,53 & 100 & 1468 & 76 & 100 & 470 & 77842 \\
\hline & 5 & 3826 & 94 & 2,46 & 99,53 & 1925 & 48 & 78,86 & 388 & 66486 \\
\hline & 6 & 3336 & 104 & 3,12 & 99,94 & 1950 & 77 & 94,72 & 390 & 58319 \\
\hline & 7 & 2370 & 39 & 1,65 & 99,96 & 818 & 28 & 88,02 & 302 & 41048 \\
\hline & 8 & 1497 & 66 & 4,41 & 100 & 1354 & 67 & 74,15 & 188 & 26119 \\
\hline & 10 & 793 & 18 & 2,27 & 100 & 381 & 17 & 100 & 91 & 13805 \\
\hline & 11 & 797 & 28 & 3,51 & 100 & 632 & 33 & 99,68 & 129 & 13739 \\
\hline & 12 & 841 & 24 & 2,85 & 99,88 & 480 & 20 & 100 & 83 & 13132 \\
\hline \multirow{12}{*}{34} & Total & 80961 & 1460 & 1,80 & 97,44 & 31964 & 1219 & 82,52 & 3658 & 700790 \\
\hline & 1 & 13516 & 230 & 1,70 & 89,01 & 4138 & 170 & 51,06 & 558 & 115905 \\
\hline & 2 & 12374 & 282 & 2,28 & 97,64 & 5924 & 224 & 98,63 & 557 & 107346 \\
\hline & 3 & 10953 & 290 & 2,65 & 99,97 & 6446 & 204 & 67,31 & 479 & 92275 \\
\hline & 4 & 10947 & 152 & 1,39 & 99,69 & 3384 & 131 & 99,38 & 475 & 94758 \\
\hline & 5 & 9333 & 170 & 1,82 & 97,21 & 3938 & 142 & 94,9 & 391 & 81732 \\
\hline & 6 & 8218 & 148 & 1,80 & 99,98 & 3369 & 130 & 91,07 & 395 & 72861 \\
\hline & 7 & 6047 & 35 & 0,58 & 100 & 1006 & 58 & 99,6 & 308 & 53045 \\
\hline & 8 & 3697 & 78 & 2,11 & 100 & 1748 & 77 & 99,31 & 191 & 32582 \\
\hline & 10 & 1980 & 12 & 0,61 & 100 & 361 & 15 & 95,29 & 91 & 17494 \\
\hline & 11 & 1950 & 34 & 1,74 & 100 & 757 & 33 & 99,87 & 129 & 17092 \\
\hline & 12 & 1946 & 29 & 1,49 & 100 & 893 & 35 & 8,4 & 84 & 15699 \\
\hline
\end{tabular}


medRxiv preprint doi: https://doi.org/10.1101/2022.02.04.22270304; this version posted February $6,2022$. The copyright holder for this preprint (which was not certified by peer review) is the author/funder, who has granted medRxiv a license to display the preprint in perpetuity.

It is made available under a CC-BY-NC-ND 4.0 International license.

\section{Extended data Table 4}

\begin{tabular}{|c|c|c|c|c|c|c|c|c|c|c|}
\hline $\begin{array}{l}\text { Calendar } \\
\text { week }\end{array}$ & $\begin{array}{l}\text { Lab } \\
\text { ID }\end{array}$ & $\begin{array}{l}\text { Pool- } \\
\text { PCRs } \\
\text { (n) }\end{array}$ & $\begin{array}{l}\text { Positive } \\
\text { Pool-PCRs } \\
\text { (n) }\end{array}$ & $\begin{array}{c}\text { Positive } \\
\text { Pool-PCRs } \\
(\%)\end{array}$ & $\begin{array}{c}\text { Pool-PCR } \\
\text { results } \\
\text { before } \\
\text { 6:00 a.m. } \\
(\%)\end{array}$ & $\begin{array}{l}\text { Single- } \\
\text { PCRs } \\
\text { (n) }\end{array}$ & $\begin{array}{c}\text { Positive } \\
\text { Single-PCRs } \\
\text { (n) }\end{array}$ & $\begin{array}{c}\text { Single- } \\
\text { PCRs } \\
\text { results } \\
\text { before } \\
\text { 6:00 a.m. } \\
(\%)\end{array}$ & $\begin{array}{l}\text { Schools } \\
\text { (n) }\end{array}$ & $\begin{array}{c}\text { Pupils } \\
\text { (estimated } n \text { ) }\end{array}$ \\
\hline \multirow{12}{*}{35} & Total & 78774 & 1080 & 1,37 & 97,84 & 23753 & 1108 & 91,66 & 3664 & 682013 \\
\hline & 1 & 13299 & 196 & 1,47 & 98,53 & 3638 & 151 & 90,08 & 559 & 113928 \\
\hline & 2 & 12166 & 209 & 1,72 & 99,84 & 4159 & 182 & 99,93 & 561 & 105488 \\
\hline & 3 & 10878 & 138 & 1,27 & 99,98 & 3319 & 117 & 76,74 & 479 & 91800 \\
\hline & 4 & 10730 & 107 & 1,00 & 99,79 & 2483 & 134 & 99,56 & 475 & 93003 \\
\hline & 5 & 9170 & 174 & 1,90 & 84,22 & 3908 & 217 & 84,08 & 391 & 80335 \\
\hline & 6 & 8172 & 109 & 1,33 & 99,88 & 2481 & 113 & 91,98 & 395 & 72603 \\
\hline & 7 & 5939 & 30 & 0,51 & 100 & 666 & 36 & 99,1 & 308 & 52063 \\
\hline & 8 & 2649 & 39 & 1,47 & 99,96 & 1031 & 54 & 99,32 & 191 & 23385 \\
\hline & 10 & 1925 & 26 & 1,35 & 100 & 582 & 33 & 100 & 92 & 17003 \\
\hline & 11 & 1933 & 28 & 1,45 & 100 & 523 & 29 & 100 & 129 & 16966 \\
\hline & 12 & 1913 & 24 & 1,25 & 100 & 963 & 42 & 100 & 84 & 15439 \\
\hline \multirow{12}{*}{36} & Total & 79490 & 912 & 1,15 & 99,92 & 19674 & 770 & 90,89 & 3665 & 688035 \\
\hline & 1 & 13310 & 188 & 1,41 & 99,86 & 3365 & 119 & 96,52 & 560 & 114052 \\
\hline & 2 & 12290 & 137 & 1,11 & 100 & 2884 & 99 & 100 & 561 & 106505 \\
\hline & 3 & 10811 & 157 & 1,45 & 100 & 3615 & 139 & 62,07 & 479 & 91198 \\
\hline & 4 & 10625 & 88 & 0,83 & 99,72 & 2397 & 90 & 99,79 & 475 & 92074 \\
\hline & 5 & 9127 & 126 & 1,38 & 99,96 & 2647 & 95 & 98,07 & 392 & 79933 \\
\hline & 6 & 8167 & 73 & 0,89 & 99,98 & 1617 & 68 & 90,79 & 395 & 72564 \\
\hline & 7 & 5739 & 40 & 0,70 & 99,9 & 931 & 53 & 90,12 & 308 & 50170 \\
\hline & 8 & 3631 & 45 & 1,24 & 100 & 915 & 44 & 99,67 & 191 & 31987 \\
\hline & 10 & 1923 & 15 & 0,78 & 100 & 372 & 13 & 99,46 & 91 & 16988 \\
\hline & 11 & 1933 & 24 & 1,24 & 100 & 520 & 38 & 99,42 & 129 & 16996 \\
\hline & 12 & 1934 & 19 & 0,98 & 99,9 & 411 & 12 & 100 & 84 & 15569 \\
\hline \multirow{12}{*}{37} & Total & 80409 & 737 & 0,92 & 99,91 & 15557 & 585 & 96,34 & 3666 & 696057 \\
\hline & 1 & 13495 & 103 & 0,76 & 99,67 & 1433 & 51 & 86,67 & 561 & 115673 \\
\hline & 2 & 12332 & 125 & 1,01 & 99,94 & 2516 & 95 & 99,96 & 562 & 106949 \\
\hline & 3 & 10989 & 146 & 1,33 & 99,97 & 3094 & 103 & 99,58 & 479 & 92600 \\
\hline & 4 & 10864 & 66 & 0,61 & 99,87 & 1625 & 60 & 99,63 & 475 & 94076 \\
\hline & 5 & 9228 & 83 & 0,90 & 99,97 & 2043 & 65 & 99,56 & 391 & 80839 \\
\hline & 6 & 8213 & 61 & 0,74 & 99,96 & 1414 & 50 & 82,04 & 395 & 73065 \\
\hline & 7 & 5837 & 52 & 0,89 & 100 & 1253 & 58 & 92,74 & 308 & 51034 \\
\hline & 8 & 3652 & 47 & 1,29 & 99,97 & 1051 & 48 & 99,71 & 191 & 32194 \\
\hline & 10 & 1945 & 11 & 0,57 & 100 & 272 & 13 & 99,63 & 91 & 17182 \\
\hline & 11 & 1922 & 21 & 1,09 & 100 & 460 & 18 & 100 & 129 & 16854 \\
\hline & 12 & 1932 & 22 & 1,14 & 100 & 396 & 24 & 100 & 84 & 15590 \\
\hline
\end{tabular}

